\title{
Extreme extension across Seram and Ambon, eastern Indonesia: evidence for Banda slab rollback
}

\author{
J. M. Pownall, R. Hall, and I. M. Watkinson \\ SE Asia Research Group, Department of Earth Sciences, Royal Holloway University of London, Egham TW20 0EX, UK \\ Correspondence to: J. M. Pownall (j.pownall@es.rhul.ac.uk)
}

Received: 19 March 2013 - Published in Solid Earth Discuss.: 17 April 2013

Revised: 29 July 2013 - Accepted: 4 August 2013 - Published: 24 September 2013

\begin{abstract}
The island of Seram, which lies in the northern part of the $180^{\circ}$-curved Banda Arc, has previously been interpreted as a fold-and-thrust belt formed during arc-continent collision, which incorporates ophiolites intruded by granites thought to have been produced by anatexis within a metamorphic sole. However, new geological mapping and a re-examination of the field relations cause us to question this model. We instead propose that there is evidence for recent and rapid $\mathrm{N}-\mathrm{S}$ extension that has caused the hightemperature exhumation of lherzolites beneath low-angle lithospheric detachment faults that induced high-temperature metamorphism and melting in overlying crustal rocks. These "Kobipoto Complex" migmatites include highly residual AlMg-rich garnet + cordierite + sillimanite + spinel + corundum granulites (exposed in the Kobipoto Mountains) which contain coexisting spinel+quartz, indicating that peak metamorphic temperatures likely approached $900^{\circ} \mathrm{C}$. Associated with these residual granulites are voluminous MioPliocene granitic diatexites, or "cordierite granites", which crop out on Ambon, western Seram, and in the Kobipoto Mountains and incorporate abundant schlieren of spineland sillimanite-bearing residuum. Quaternary "ambonites" (cordierite + garnet dacites) emplaced on Ambon were also evidently sourced from the Kobipoto Complex migmatites as demonstrated by granulite-inherited xenoliths. Exhumation of the hot peridotites and granulite-facies Kobipoto Complex migmatites to shallower structural levels caused greenschistto lower-amphibolite facies metapelites and amphibolites of the Tehoru Formation to be overprinted by sillimanite-grade metamorphism, migmatisation, and limited localised anatexis to form the Taunusa Complex. The extreme extension required to have driven Kobipoto Complex exhumation evidently occurred throughout Seram and along much of the
\end{abstract}

northern Banda Arc. The lherzolites must have been juxtaposed against the crust at typical lithospheric mantle temperatures in order to account for such high-temperature metamorphism and therefore could not have been part of a cooled ophiolite. In central Seram, lenses of peridotites are incorporated with a major left-lateral strike-slip shear zone (the "Kawa Shear Zone"), demonstrating that strike-slip motions likely initiated shortly after the mantle had been partly exhumed by detachment faulting and that the main strike-slip faults may themselves be reactivated and steepened lowangle detachments. The geodynamic driver for mantle exhumation along the detachment faults and strike-slip faulting in central Seram is very likely the same; we interpret the extreme extension to be the result of eastward slab rollback into the Banda Embayment as outlined by the latest plate reconstructions for Banda Arc evolution.

\section{Introduction}

Eastern Indonesia (Fig. 1) is the product of complex collision between Eurasia, Australia, and the Pacific (Caroline and Philippine Sea plates) since the Late Oligocene (van Bemmelen, 1949; Hamilton, 1979; Bowin et al., 1980; Katili, 1989; Milsom et al., 2001; Hall, 2002, 2012; Hinschberger et al., 2005; Harris, 2006; Nugroho et al., 2009; Villeneuve et al., 2010; Watkinson et al., 2012). Much of the convergence has been accommodated by northward subduction of the Indian Ocean along the Sunda Trench (Widiyantoro and van der Hilst, 1997), by left-lateral slip within the Sorong Fault Zone across northernmost New Guinea (Visser and Hermes, 1962; Pieters et al., 1983; Charlton, 1996), and by the complete subduction of the double-dipping Molucca Sea 
slab eastwards beneath Halmahera and westwards beneath Sulawesi (McCaffrey et al., 1980). However, of all the major lithospheric features of eastern Indonesia involved in recent convergence, the Banda Arc, with its extreme $180^{\circ}$ curvature about a tight $250 \mathrm{~km}$ radius, is in many ways the most striking and enigmatic.

Earthquake hypocentre determination (Cardwell and Isacks, 1978; Das, 2004) combined with seismic tomography (Widiyantoro and van der Hilst, 1997; Spakman and Hall, 2010) have revealed the subducted lithosphere morphology of the Banda Arc to approximate the bow of a $500 \mathrm{~km}$ wide ship, sailing due east, whose hull rests on the $660 \mathrm{~km}$ depth mantle discontinuity (Fig. 2). The arc has evidently facilitated subduction of the Australian continental margin beneath the Eurasian Banda Sea, but the nature of this subduction cannot be simply explained by a conventional Sunda Arc-type mechanism because this would require simultaneous north-, west-, and south-directed subduction of the same plate.

Considerable controversy has centred around how such a subduction geometry has been attained (Hall and Wilson, 2000; Milsom et al., 2001, and references therein). Some authors, largely based on interpretation of seismic and geochemical trends, have proposed that the geometry of the Banda Arc is created by two separate slabs - a southwarddipping slab beneath Seram forming the northern portion of the arc, and a northward-dipping slab beneath Timor forming the southern portion - which have coincidentally sutured along their junction (Cardwell and Isacks, 1978; McCaffrey, 1988, 1989; Stevens et al., 2002; Bock et al., 2003; Das, 2004; Hinschberger et al., 2005; Fichtner et al., 2010; Špičák et al., 2013). Although more plausible than early models that proposed the Banda Arc represents an eastward continuation of the Sunda Arc subsequently flexed through $180^{\circ}$ (AudleyCharles et al., 1972; Katili, 1975), these two-slab hypotheses run into problems when placed into a regional plate-tectonic context (Hall, 2002, 2011; Spakman and Hall, 2010). Specifically, they require prior existence of oceanic crust between Seram and the Bird's Head (West Papua), at least $2000 \mathrm{~km}$ of $\mathrm{N}-\mathrm{S}$ shortening across the Banda region between Australia and Halmahera to have occurred in the last $6 \mathrm{Ma}$, and a westward continuation of the Tarera-Aiduna Fault from south of the Bird's Head to have sutured the two slabs and to have accommodated their differences in motion. There is no geological evidence for any of these features, and furthermore, a two-slab model cannot account for the seemingly perfect continuity of the extremely curved portions of the subducted slab imaged by earthquake hypocentres and seismic tomography at depth (see Milsom et al., 2001).

Alternatively, it has been proposed that the formation of the Banda Arc involves subduction rollback (Hamilton, 1979; Hall, 1996, 2002, 2011, 2012; Milsom et al., 2001; Hinschberger et al., 2005; Harris, 2006; Spakman and Hall, 2010; Widiyantoro et al., 2011). Recent plate reconstructions by Hall $(1996,2002,2011,2012)$ and Spakman and Hall
(2010) have modelled the rollback of a single slab into a preexisting D-shaped oceanic embayment in the Australian continental margin. The old, cold, and negatively buoyant Jurassic oceanic lithosphere which occupied the Banda Embayment, termed the Proto-Banda Sea, is thought to have readily collapsed upon invasion by the advancing Java subduction zone at $16 \mathrm{Ma}$, causing eastward rollback of the subduction zone into the Banda Embayment (Spakman and Hall, 2010; Hall, 2012). These authors also proposed that during this event, the encircling buoyant continental crust of the Sula Spur and NW Australian margin would have resisted subduction, thereby forcing the slab to assume its extreme curvature and likely dictating its rollback velocity. This singleslab rollback model has since been supported by seismic tomography studies (Widiyantoro et al., 2011). However, field relations on Seram and Ambon have been explained by alternative models. For instance, the island has previously been interpreted as a fold-and-thrust belt incorporating northwardobducted ophiolites (Linthout et al., 1989, 1996). In contrast, a rollback scenario would require crustal extension and so peridotite emplacement by long-distance thrusting would seem implausible.

This paper documents the findings of recent and extensive fieldwork undertaken by the authors on Seram and Ambon between 2010 and 2012. We first provide a synthesis of previously published field reports (Valk, 1945; Germeraad, 1946; van der Sluis, 1950; Audley-Charles et al., 1979; Tjokrosapoetro and Budhitrisna, 1982; de Smet and Barber, 1992) and geophysical surveys (Milsom, 1979; Milsom et al., 2001; Bock et al., 2003; Das, 2004; Widiyantoro and van der Hilst, 1997; Spakman and Hall, 2010) combined with ASTER digital elevation model (DEM) interpretation. We present a series of new small-scale geological maps for a number of key areas around Seram alongside a revised geological sketch-map for the whole island (Fig. 3).

\section{The geology of Seram and Ambon: a synopsis of previous work}

Seram is a relatively large island $(350 \times 75 \mathrm{~km})$ characterised by a mountainous topography (surpassing $3 \mathrm{~km}$ elevation), dense jungle, and a tropical rainforest climate. Nearly all of the island's interior is accessible only by foot via stream traverses from the coast and therefore remains poorly explored. The much smaller volcanic island of Ambon lies to Seram's immediate southwest.

An outline of the geology of Seram and Ambon was first provided by early pioneers - western Seram comprises a metamorphic basement of schists, amphibolites, and gneisses associated with ultramafic complexes and unusual cordieritebearing granites (Martin, 1901; Schroeder van der Kolk, 1902; Wanner, 1907; Deninger, 1915); the Manusela Mountains of central Seram and the hills to their north and east consist mainly of extensive carbonate successions, shales, and 


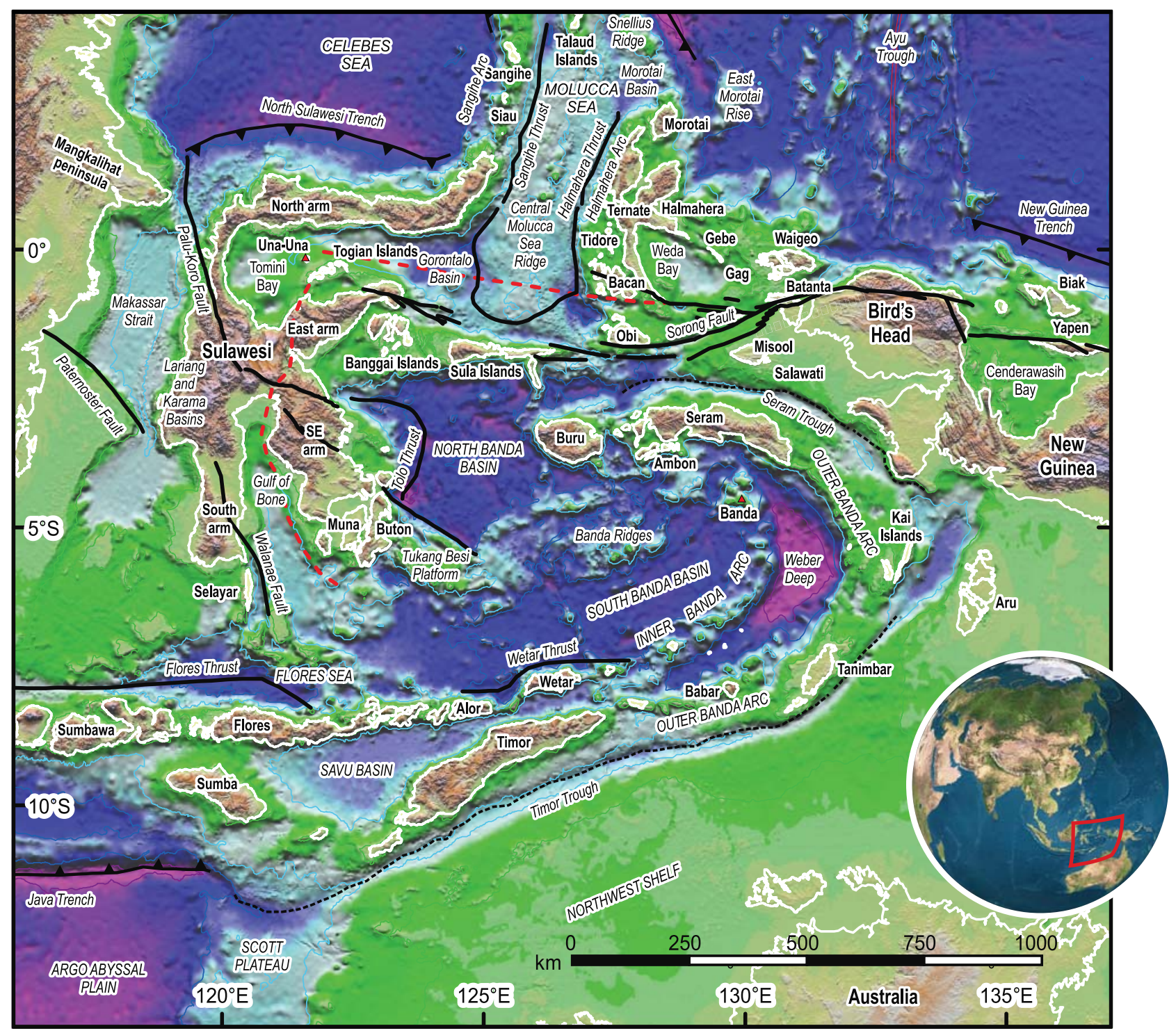

Fig. 1. SRTM image of eastern Indonesia showing the Banda Arc and the location of the islands of Seram and Ambon. Faults are marked by solid black lines; subduction zones are indicated by toothed black lines; the surface expression of Banda Arc subduction - the Seram Trough and Timor Trough - are indicated by dashed black lines. The dashed red line shows the approximate limit of the Sula Spur (from Hall, 2012). Inset (bottom-right) indicates map location in SE Asia.

sandstones (Wanner, 1907, 1923; Deninger, 1918; Brouwer, 1919; Krumbeck, 1922); and Ambon is formed mainly of unusual cordierite-rich dacites in addition to granites and ultramafic rocks similar to those present in western Seram (Verbeek, 1905; Brouwer, 1925). Between 1917 and 1919, Seram was systematically surveyed by the "Ceram Expidite" led by Dutch geologists L. M. R. Rutten and W. Hotz (Rutten, 1918a, b, c, d, 1919a, b, c, d, 1927; Rutten and Hotz, 1919, 1920a, b), with summaries of field observations and geological maps later presented in a series of theses by Valk (1945), Germeraad (1946), and van der Sluis (1950) for western, central, and eastern Seram respectively. The Ceram Expidite remains the largest undertaking of its kind on Seram and formed the basis for many of the subsequent interpretations by the Indonesian geological survey, the GRDC (Tjokrosapoetro and Budhitrisna, 1982), and seems to have underpinned the latest editions of the organisation's geological maps for western Seram and Ambon (Tjokrosapoetro et al., 1993b), central Seram (Tjokrosapoetro et al., 1993a), and eastern Seram (Gafoer et al., 1993).

Fieldwork by the Southeast Asia Research Group (SEARG) based at the University of London (AudleyCharles et al., 1979; Milsom, 1977, 1979; John and Barber, 1990; Papaioannou, 1991; de Smet and Barber, 1992; Spakman and Hall, 2010; Pownall et al., 2012a, b, c, 2013a, b, c; Watkinson et al., 2012), the Dutch Snellius II programme 


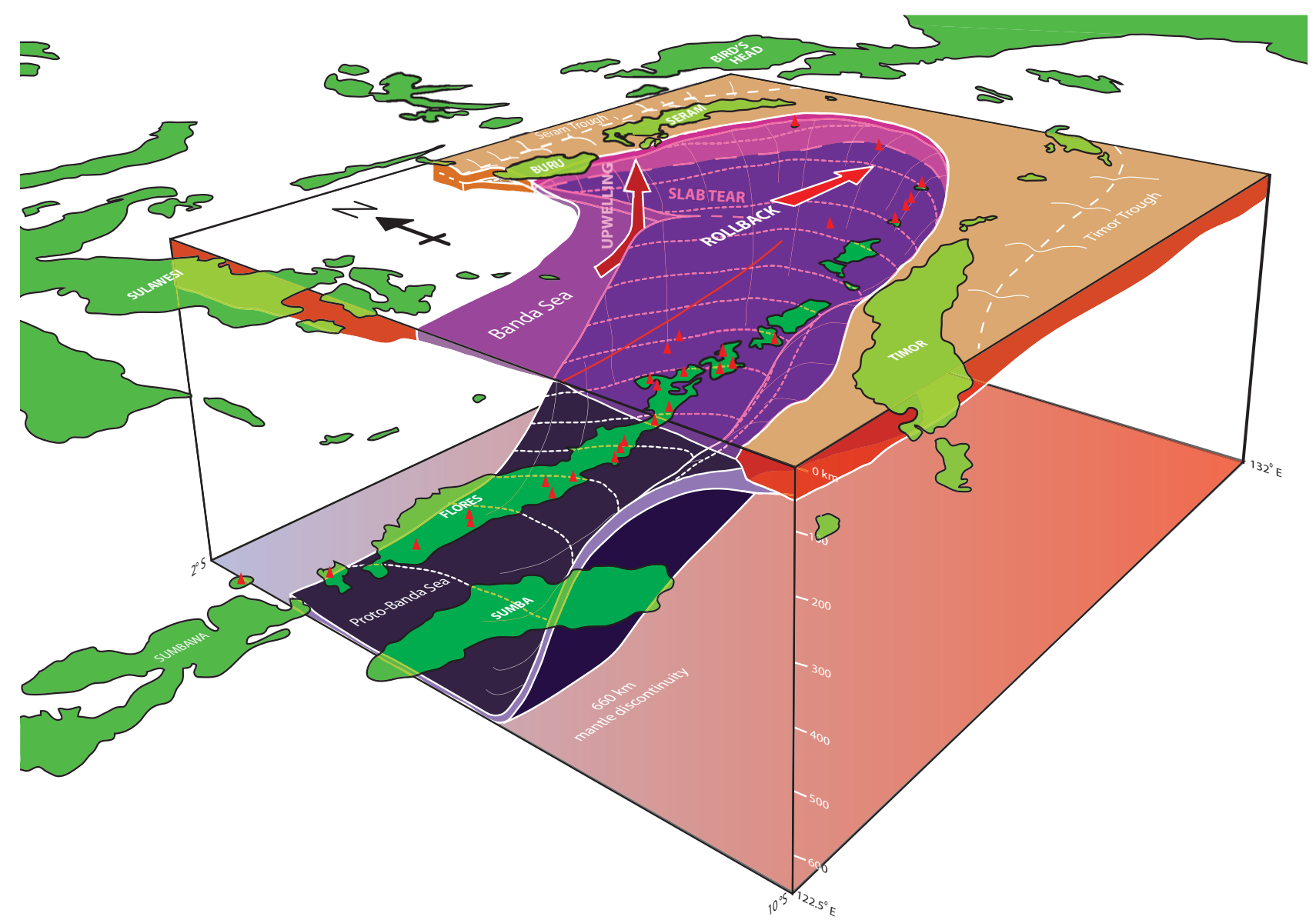

Fig. 2. A 3-D model of the Banda Arc based on earthquake hypocentre locations (Das, 2004) and seismic tomography (Spakman and Hall, 2010). Eastward subduction rollback of the Proto-Banda Sea (dark purple) into a pre-existing D-shaped embayment in the Australian continental margin (light brown) is thought to explain the slab's extreme curvature. An aseismic zone beneath Buru is interpreted to be due to a tear in the slab that has caused the northern part of the slab west of Buru to have detached and collapsed into the mantle to rest on the $660 \mathrm{~km}$ discontinuity. The box is drawn between $122.5-132^{\circ} \mathrm{E}$ and $2-10^{\circ} \mathrm{S}$ to $660 \mathrm{~km}$ depth. Red triangles represent volcanoes.

(de Smet, 1989; de Smet et al., 1989a, b; van Hinte and Hartono, 1989; Helmers et al., 1989; Linthout et al., 1989, 1991, 1996, 1997; Linthout and Helmers, 1994), and by oil companies working in eastern Seram and the Seram Trough (Zillman and Paten, 1975; O'Sullivan et al., 1985; Price et al., 1987; Kemp and Mogg, 1992; Pairault et al., 2003a, b; Charlton, 2004; Teas et al., 2009; Darman and Reemst, 2012) represents the bulk of previous research carried out on and around the islands.

More than ten different stratigraphic schemes have been proposed for Seram, with names for equivalent units changing from publication to publication (Fig. 4). Therefore, a review of previous work is necessary in order to draw comparisons with our own observations. Several tectonic proposals for Seram are also discussed below.

\subsection{Metamorphic complexes}

Metamorphic rocks, which crop out in western Seram, comprise Barrovian-type phyllites, schists, and gneisses. Three subdivisions have usually been drawn (in stratigraphic order and decreasing metamorphic grade): (1) The Old Crystalline Schists of Valk (1945) and Germeraad (1946), later named the "Kobipoto Complex" by Audley-Charles et al. (1979), which includes granulite facies metapelites, migmatites, and gneisses that are present in the Kobipoto Mountains; (2) Widespread mica schists, amphibolites, and phyllites of the Tehoru and Taunusa Complexes, proposed by AudleyCharles et al. (1979) and Tjokrosapoetro and Budhitrisna (1982) respectively, which are equivalent to the Formation of Crystalline Schists and Phyllites of Valk (1945); and (3) Low-grade slates and marbles ascribed to the Saku Formation of Tjokrosapoetro and Budhitrisna (1982), equivalent to the Graywacke and Glossy Slate Formationof Valk (1945) 
and included in the Kaibobo Complex of Audley-Charles et al. (1979).

The Kobipoto Complex is best exposed in the remote Kobipoto Mountains of central Seram (Rutten, 1918b; Germeraad, 1946; Audley-Charles et al., 1979; de Smet and Barber, 1992; Tjokrosapoetro et al., 1993a) and the vicinity of Gunung Langget in southwest Seram (van der Sluis, 1950; Gafoer et al., 1993). High-grade metamorphic rocks are found in association with variably serpentinised peridotites. Audley-Charles et al. (1979) made the distinction between two types of gneiss from the Kobipoto Mountains found as boulders in the gorges of the Wai (river) Isal and Wai Tuh: (a) metatexites ${ }^{1}$ with quartzofeldspathic segregations and complex folding containing large garnets and green spinel; and (b) coarser-grained granitic diatexites containing biotite, cordierite, garnet, staurolite, and andalusite, with xenoliths containing sillimanite and green spinel. AudleyCharles et al. (1979) suggested both types were metamorphosed under granulite facies conditions in the lower crust until the onset of anatexis, with the aluminous xenoliths representing residua after partial melting. Boulders of serpentinite are described from the same rivers by AudleyCharles et al. (1979, p. 560) who suggested their relationship with other Kaibobo Complex rocks "could be tectonic". Staurolite-grade metapelites, amphibolites, and calc-silicates also occur in the complex although their structural position remains unknown (Germeraad, 1946; Audley-Charles et al., 1979; de Smet and Barber, 1992). The Kobipoto Complex is known to be locally faulted against Kanikeh Formation siltstones and conglomorates, but the fundamental tectonic setting of the complex remains unresolved. Germeraad (1946) and van der Sluis (1950) envisaged the Kobipoto Complex was exhumed from the base of the crust by normal faulting. Audley-Charles et al. (1979) and de Smet and Barber (1992) instead suggested the complex is an allochthonous unit which has been thrust over the Kanikeh Formation from the south, with tectonic breccias of granulites, schists, and sandstones interpreted to structurally underlie the inferred thrust plane (Papaioannou, 1991). Furthermore, de Smet and Barber (1992) ascribed the serpentinites of the complex to a large ophiolite, as hypothesised by Linthout et al. (1989), which was once thought to cover much of Seram. The Kobipoto Complex has not yet been dated, although a Precambrian age was suggested by Audley-Charles et al. (1979) who proposed that it was derived from northern Australia.

The Tehoru Formation includes mainly upper-greenschist to lower-amphibolite facies metapelites of possible turbiditic origin intercalated with amphibolites formed by metamorphism of associated basalts. Garnets are common in the higher grade schists, although rarer staurolite, sillimanite, and kyanite-bearing schists have also been reported from river float (Valk, 1945) indicating the Tehoru Formation

\footnotetext{
${ }^{1}$ Migmatite terminology used in this paper follows Sawyer (2008).
}

also includes rocks of at least mid-amphibolite facies grade. Linthout et al. (1989) identified three distinct deformational episodes $\left(\mathrm{D}_{1}-\mathrm{D}_{3}\right)$ which caused intensive folding and associated crenulation cleavage development. The authors also described mylonitic fabrics overprinting $\mathrm{D}_{1}-\mathrm{D}_{3}$ where the rocks are juxtaposed against the Saku Formation by a major strike-slip fault (named here the Kawa Fault after the river that runs down most of its length) which runs south of the Manusela Mountains. A maximum peak metamorphic temperature of $613^{\circ} \mathrm{C}$ was calculated for St-Grt schists south of these mylonites, and the rocks also recorded later cooling to $475^{\circ} \mathrm{C}$ at $1.5 \mathrm{kbar}$ (Linthout et al., 1989).

The Taunusa Complex, as defined by the GRDC (Tjokrosapoetro and Budhitrisna, 1982; Tjokrosapoetro et al., 1993a, b), is very similar in many ways to the Tehoru Formation although it includes rocks previously assigned to Valk's (1945) "Crystalline Schists" and therefore is considered to be generally of higher metamorphic grade (mid/upperamphibolite facies rather than lower-amphibolite to greenschist facies). Furthermore, a boulder of lower-granulite facies garnet-pyroxene metagabbro from the headwaters of the Wai Mala (which flows southward into Teluk Elaputih) was also assigned to Valk's (1945) Crystalline Schists by AudleyCharles et al. (1979). The Taunusa Complex has been interpreted to occupy higher thrust sheets than the Tehoru Complex in the Wallace Mountains (Tjokrosapoetro et al., 1985, 1987). Sillimanite-grade schists and gneisses north of the ultramafic complex present on the Kaibobo Peninsula, which were reclassified as Taunusa Complex by Tjokrosapoetro et al. (1985), were shown by Linthout et al. (1989) to have been metamorphosed at temperatures surpassing $700^{\circ} \mathrm{C}$ (at $>4$ kbar). Linthout et al. (1989, 1996) and Linthout and Helmers (1994) considered the ultramafic rocks to be ophiolitic, and interpreted these high-temperature gneisses to be the products of sub-ophiolite metamorphism; according to this "Seram Ophiolite" model, the Taunusa Complex represents a high-temperature metamorphic overprint of the Tehoru Complex, as opposed to being a separate tectonometamorphic unit.

The Saku Formation was defined by Tjokrosapoetro et al. (1993a) to include Triassic slate, metagreywacke, metaarkose, and marbles. The Saku and Taunusa complexes together represent what was previously described by AudleyCharles et al. (1979) as the Kaibobo Complex. Confusingly, rocks of the Kaibobo Complex are not present on the Kaibobo Peninsula after which they were presumably named.

\subsection{Limestones of the Manusela Mountains}

The $3000 \mathrm{~m}$ Manusela Mountains of central Seram are formed from Lower Triassic to Middle Jurassic shallowwater carbonates and shales, named by various authors as the Manusela Formation, Asinipe Limestone, Saman Saman Limestone, and/or Coralligenous Limestone (see Fig. 4 and references therein). Martin (1901, 1903), Deninger (1918), 


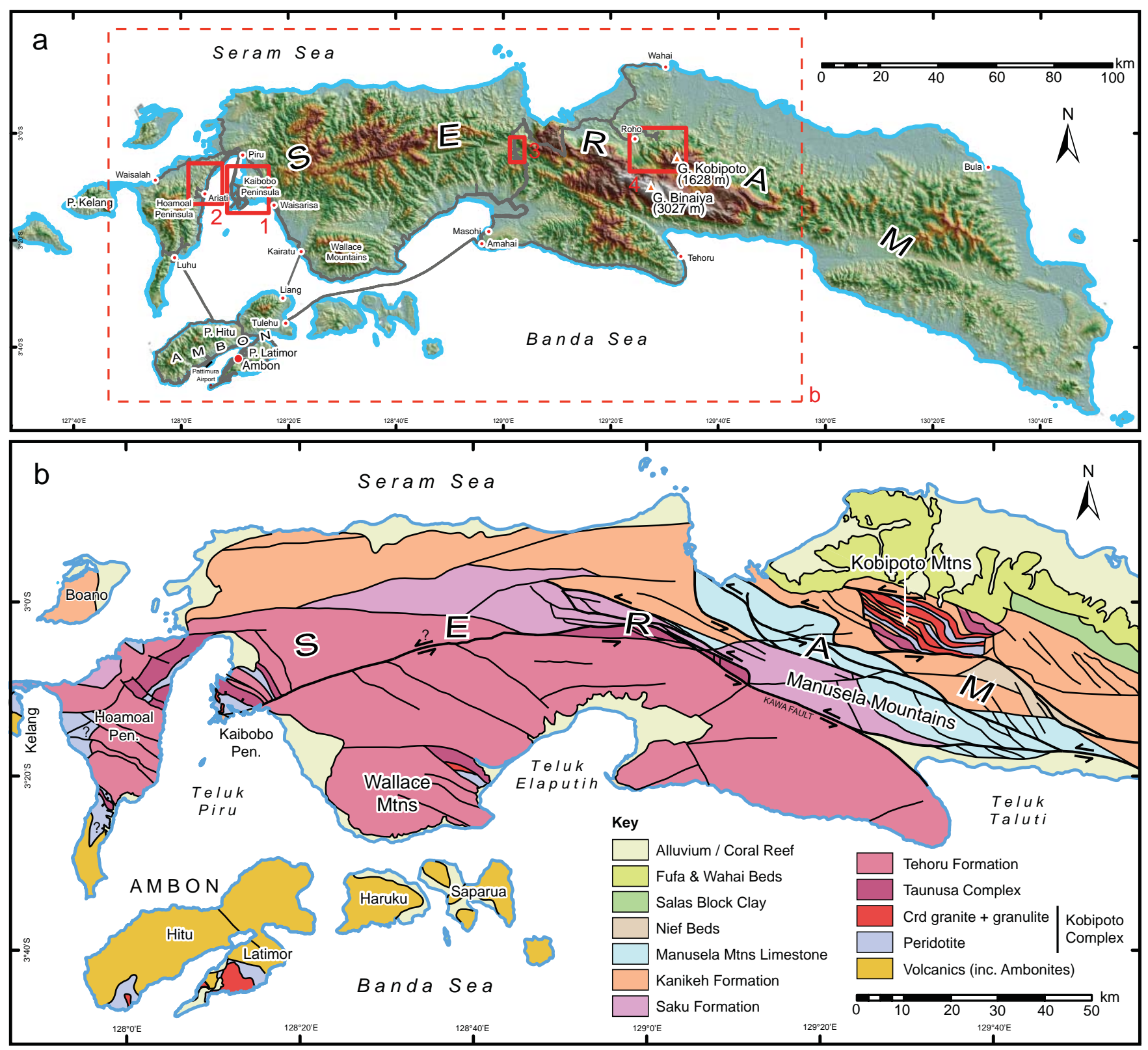

Fig. 3. (a) SRTM image of Seram and Ambon. Red boxes show the locations of the included maps: (1) Kaibobo Peninsula - see Fig. 5; (2) NW Hoamoal Peninsula - see Fig. 9; (3) Central Kawa Fault Zone - see Fig. 11; (4) Kobipoto Mountains - see Fig. 14. The dashed red box shows the location of map (b). (b) Geological sketch map of western and central Seram and Ambon compiled from new geological field mapping, DEM fault interpretation, and previously published maps (Valk, 1945; Germeraad, 1946; Tjokrosapoetro et al., 1993a, b). The schematic logs presented in Fig. 4 are shown in the same colour schemes to allow direct correlation with the map.

Valk (1945), and Germeraad (1946) provided the earliest accounts of the central Seram carbonates, describing them as a single thick stratigraphic sequence. However, AudleyCharles et al. (1979, p. 549) later considered the deep-water Saman Saman Limestones to be composed of "strikingly different facies and fauna" to the same-age shallow-water Asinipe Limestones and so assigned them to two different terranes which were argued to have been brought into close association by large scale thrusting; the Saman Saman Lime- stones were regarded as autochthonous Australian units, with the Asinipe Limestone being part of an Asian allochthon tentatively proposed to have been thrust from Eastern Java or Southern Sulawesi. However, subsequent authors (Tjokrosapoetro and Budhitrisna, 1982; de Smet and Barber, 1992) dismissed this two-terrane idea, arguing that the different facies simply represent coeval depocentres on the slope of the Australian shelf. Furthermore, Martini et al. (2004) later found that Asinipe-type limestones occur in both 


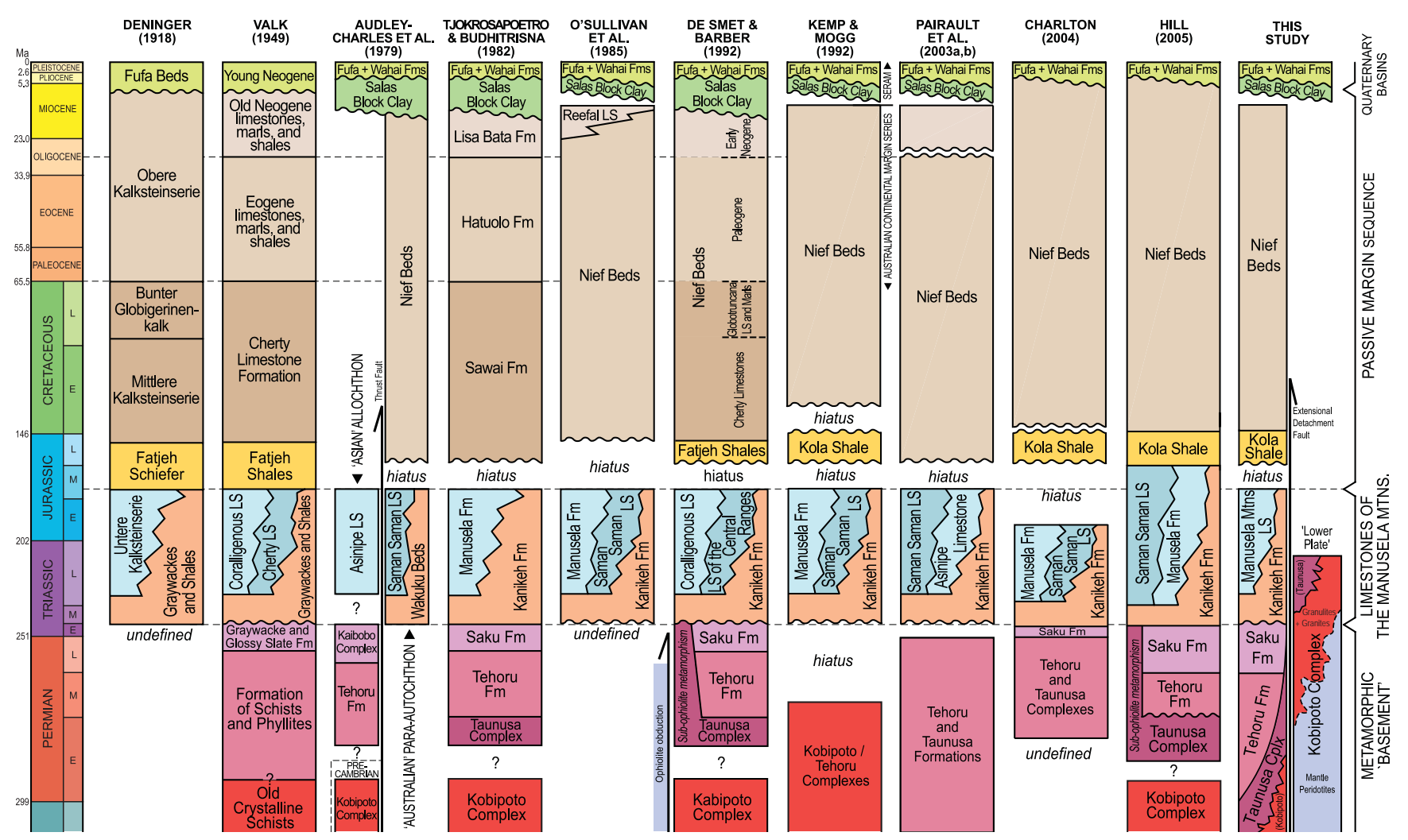

Fig. 4. Comparison of the ten main previous chronostratigraphical proposals for Seram, arranged in chronological order to show the progression of ideas (redrawn from Deninger, 1918; Valk, 1945; Audley-Charles et al., 1979; Tjokrosapoetro and Budhitrisna, 1982; O'Sullivan et al., 1985; de Smet and Barber, 1992; Kemp and Mogg, 1992; Pairault et al., 2003a, b; Charlton, 2004; Hill, 2005). Equivalent (and approximately equivalent) units are displayed in the same colours to allow easy correlation. Note that the stratigraphic position of the metamorphic units relates to the protolith age and not the age of metamorphism. Our reinterpretation is presented in the rightmost column. Columns for Deninger (1918), Valk (1945), Audley-Charles et al. (1979), and Tjokrosapoetro and Budhitrisna (1982) are redrawn based largely on the interpretation given by de Smet and Barber (1992). Some stratigraphic boundaries are approximate due to lack of information in the literature. "LS" = Limestone(s); "Fm(s)" = Formation(s); "Mtns" = Mountains. Geological timescale adapted from Walker and Geissman (2009).

of Audley-Charles et al.'s (1979) para-autochthon and allochthon, and could also be correlated with several carbonate formations around the Banda Sea.

Cropping out in the valley between the Manusela and Kobipoto Mountains is the Kanikeh Formation (equivalent to the Wakuku Beds of Audley-Charles et al., 1979) which consists of Triassic to Jurassic dark grey deep-water clays, siltstones, and micaceous carbonaceous sandstones (Deninger, 1918; Price, 1976; Tjokrosapoetro and Budhitrisna, 1982; de Smet and Barber, 1992). The Kanikeh Formation is thought to stratigraphically overlie the Saku Formation and to be stratigraphically overlain by, and to laterally interfinger with, the Manusela Mountain limestones (de Smet and Barber, 1992).

\subsection{Nief Beds}

An imbricated Middle Jurassic to Miocene passive margin succession of deep water carbonates and turbidites, usually referred to as the Nief Beds, crops out in northern and east- ern Seram (Valk, 1945; Germeraad, 1946; Audley-Charles et al., 1979; Tjokrosapoetro and Budhitrisna, 1982). Alongside the Kanikeh Formation, the Nief Beds were considered by Kemp and Mogg (1992) to form an "Australian Series" deposited during the rifting of Seram from the Australian continental margin, as proposed by Pigram and Panggabean (1984). The base of the Nief Beds has not been reported, although may be represented by the Fatjeh Shales (Deninger, 1918), later renamed the Kola Shales (Kemp and Mogg, 1992), through which a detachment fault has been suggested to propagate (Hill, 2005) that possibly allowed the Bird's Head to have been driven beneath the fold-and-thrust belt of northern Seram and the Seram Trough (Nilandaroe et al., 2001; Pairault et al., 2003; Charlton, 2004; Hill, 2005, 2012; Teas et al., 2009; Darman and Reemst, 2012).

\subsection{Plio-Pleistocene deposits and the Salas Block Clay}

Plio-Pleistocene sedimentary deposits of the Wahai Beds and Fufa Formation and extensive mélanges of the Salas 
Block Clay cover much of northern and eastern Seram (Zillman and Paten, 1975). Kemp and Mogg (1992) considered these beds to represent a "Seram Series" which have been exclusively derived from erosion of Triassic to Upper Miocene "Australian Series" rocks and uplifted basement. The Salas Block Clay has been interpreted as an Upper Miocene olistostrome comprising huge (metre- to kilometrescale) exotic blocks derived from landslides of the Kanikeh Formation as well as small fragments of crystalline basement (Audley-Charles et al., 1979; Tjokrosapoetro and Budhitrisna, 1982; O'Sullivan et al., 1985; Tjokrosapoetro et al., 1987). O'Sullivan et al. (1985) proposed that the Salas Block Clay was deposited initially by gravity slumping towards the Seram Trough with the resulting olistrostrome later becoming tectonically incorporated into imbricate wedges, and that the deposit therefore cannot be considered a stratigraphic unit. The Kanikeh Formation is obviously a highly mobile unit, and some authors have suggested that clay diapirism and mud volcanism operating within these and similar formations may have been significant contributors to the mélange formation of the outer Banda Arc islands (Barber et al., 1986).

The fluvial Pleistocene Fufa Formation (600 m thick) is thought to rest unconformably on mud- and siltstones of the Plio-Pleistocene Wahai Beds ( $160 \mathrm{~m}$ thick), with both units interpreted to unconformably overlie the Salas Block Clay olistostrome and Kobipoto Complex (Zillman and Paten, 1975). The "Bula Uplift" event (Zillman and Paten, 1975; de Smet et al., 1989a) is thought to have caused rapid (up to $2.5 \mathrm{~mm} \mathrm{a}^{-1}$ ) uplift of the metamorphic basement which elevated the Wahai Beds prior to deposition of the Fufa Beds. The Wallace Mountains are thought to have been uplifted over $1500 \mathrm{~m}$ during this episode (de Smet et al., 1989a; de Smet and Barber, 1992).

\section{Field relations on Seram and Ambon}

Here we present new field observations and geological mapping undertaken during recent fieldwork carried out on Seram and Ambon between 2010 and 2012.

\subsection{Kaibobo Peninsula}

The jagged coastline of the Kaibobo Peninsula juts out into Piru Bay in western Seram (Fig. 5). It has been a major focus of several previous studies (Schroeder van der Kolk, 1902; de Jong, 1923; Valk, 1945; Milsom, 1979; Milsom et al., 2001; Helmers et al., 1989; Linthout et al., 1989, 1996; Linthout and Helmers, 1994; Monnier et al., 2003; Martini et al., 2004) owing to the close association of well-exposed ultramafic rocks, large Mio-Pliocene granitoid bodies, and the Tehoru Formation and Taunusa Complex "metamorphic basement". The peninsula was first mapped in detail by Rutten and Hotz (1919). In Fig. 5, we present a new geological map of the peninsula based on a series of transects made from Kaibobo Village and localities on the coast accessed by boat. The peninsula can be broadly divided into three regions: a central ultramafic belt which includes large bodies of granite; a northern region comprising schists and gneisses of the Tehoru Formation and Taunusa Complex; and a southern region (including the island of Pulau Babi) occupied by sandstones and carbonates of the Triassic Manusela Formation (Martini et al., 2004). On the peninsula of Tanjung Motianai is a shear zone comprising mylonitised granites and sheared amphibolites.

\subsubsection{The peridotite-granite association}

Peridotites, typically serpentinised lherzolites, crop out extensively over the central and southern Kaibobo Peninsula. Some peridotite outcrops display foliations that commonly dip around $30^{\circ}$ to the north. The ultramafic rocks are in contact with two large $(1 \times 2 \mathrm{~km})$ granitoid bodies we shall refer to as the North and South Kaibobo Granites, which form a rough north-south trending chain between Teluk Latimor and Kaibobo Village (see Fig. 5 and 6). Rounded granite boulders, often several metres in diameter, are distributed throughout these regions (Fig. 7a). They have evidently been shaped by tropical onion-skin weathering rather than by erosion, as demonstrated by a number of outcrops that contain rounded granite pods positioned in situ within an extensively weathered and extremely soft "rotten" granite matrix (Fig. 7b). The recent excavation of a track leading northwards from Kaibobo Village to the Wai Latal has exposed a section of the South Kaibobo Granite that is cut by many normal faults that strike at $\sim 330^{\circ}$.

The granite is medium- to fine-grained and fairly equigranular with no megacrysts present. Biotite is abundant and muscovite is present although much scarcer. Significantly, the granite contains abundant cordierite phenocrysts, albeit fairly inconspicuous in hand sample, and in many instances garnet is present too. However, the most remarkable features of these granites are the extremely numerous $\mathrm{mm}$ - to $\mathrm{cm}$ scale blue-grey clusters of sillimanite, hercynite spinel, and cordierite (Fig. 7c) that are ubiquitous in the granites and are present in roughly equal concentration within all such "cordierite granites" encountered on Seram and Ambon. We propose these aluminous assemblages are small schlieren of residual granulite, based on field evidence from the Kobipoto Mountains, as detailed later (Sect. 3.5). These unusual rocks are extremely hard with an almost hornfels-like quality and produce a metallic ring when struck with a hammer. Linthout et al. (1996) obtained a biotite ${ }^{40} \mathrm{Ar}-{ }^{39} \mathrm{Ar}$ age of $5.51 \pm 0.02 \mathrm{Ma}$ for the North Kaibobo Granite.

The cordierite granite bodies are always separated from the peridotites by a narrow margin of leucogranite that has evidently been generated along the interface. Numerous granophyric leucogranite dykes have been injected outwards from this leucogranite body into both the adjacent peridotites 


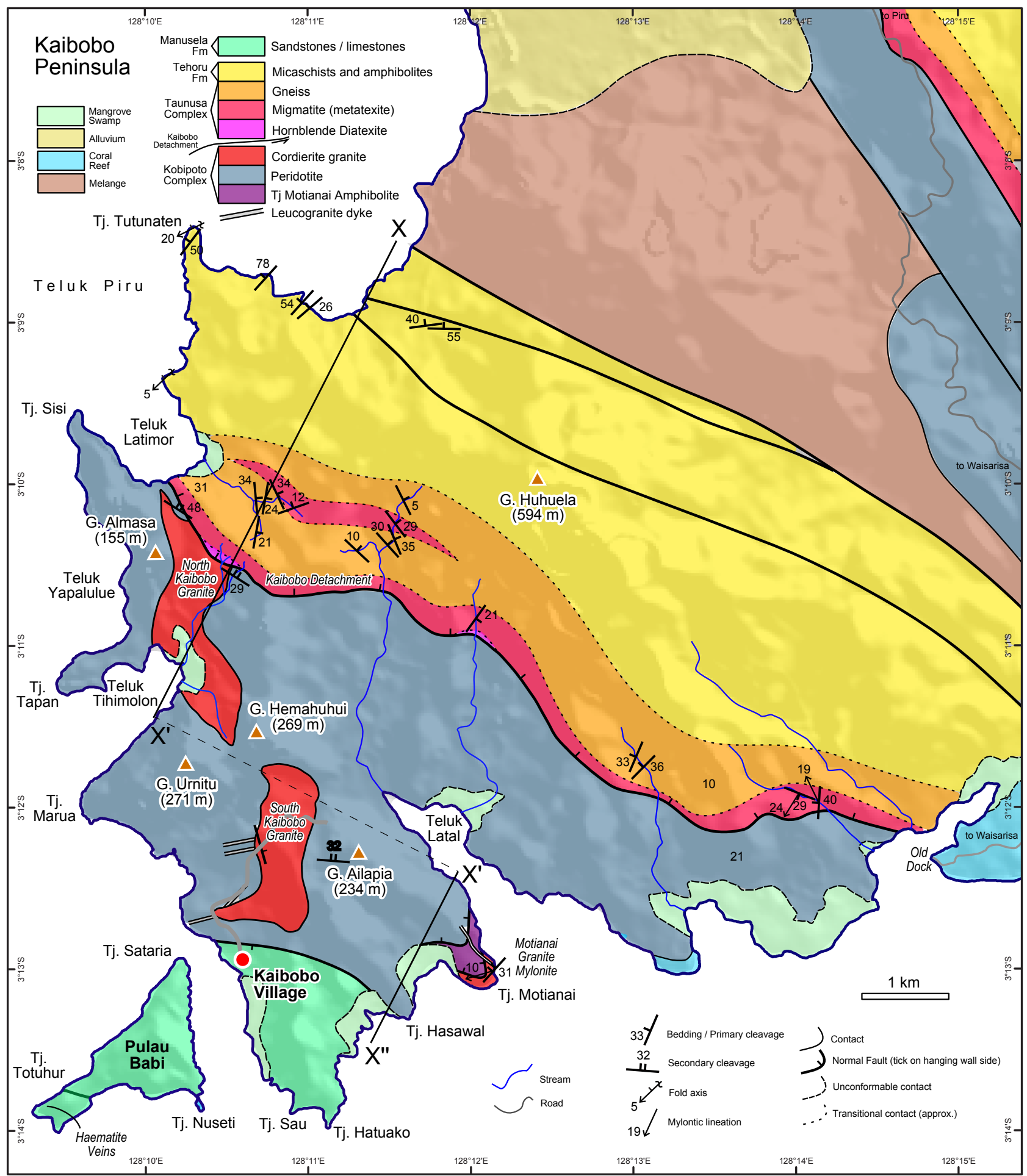

Fig. 5. Geological map of the Kaibobo Peninsula, western Seram, constructed from stream sections and coastal outcrop accessed by boat, and traverses made from Kaibobo Village. See Fig. 6 for a cross section along profile $X-X^{\prime}-X^{\prime \prime}$, and see Fig. 3 for map location.

(Fig. 7d) and cordierite granites (Fig. 7b). The leucogranite is compositionally different from the cordierite granites and is devoid of cordierite and garnet phenocrysts and sill-sp-crd schlieren. It instead has a simple mineralogy essentially of plagioclase, K-feldspar, and quartz, with granophyric intergrowths of plagioclase and quartz commonly 


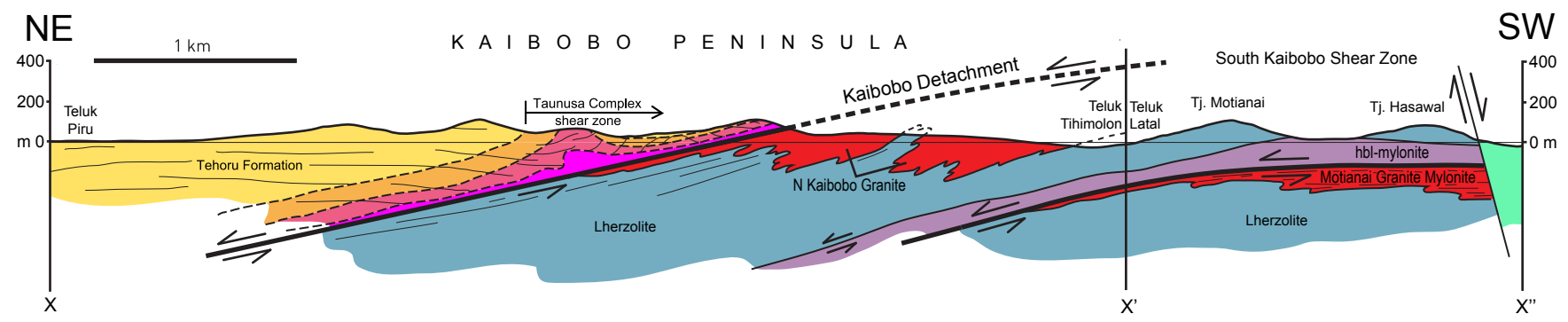

Fig. 6. Cross section $X-X^{\prime}-X^{\prime \prime}$ across the Kaibobo Detachment and South Kaibobo Shear Zone, Kaibobo Peninsula. See geological map in Fig. 5 for location and key to lithologies.

developed. The presence of prehnite in the leucogranites indicates partial metasomatism, or rodingitisation, by Ca-rich fluids produced during serpentinisation of the peridotites. The leucogranites would therefore appear to be younger than the cordierite granites, with granophyric textures hinting at rapid crystallisation at medium to low pressure. Leucogranite dykes are associated with the cordierite granite-peridotite contact wherever observed, and are not just confined to the Kaibobo Peninsula. Both the leucogranites and cordierite granites have been shot through by numerous thin serpentinite veins that emanate from the peridotite which must have formed much later during the low-temperature metasomatism associated with the leucogranite rodingitisation. At several localities, the peridotites are net-veined by pegmatitic hornblende diorite which may be related to the leucogranites, the most striking example of which is on Tanjung Sisi where the hornblende crystals are up to $10 \mathrm{~cm}$ in length (Fig. 7e).

It is important to emphasise that the cordierite granites and leucogranites are found exclusively in association with the peridotites and have never been seen to intrude the Taunusa or Tehoru metamorphic complexes. This observation conflicts with the interpretation of Linthout et al. (1989, 1996) that the granites were generated by anatexis of the Taunusa metamorphics which represented a metamorphic sole beneath an obuducted ophiolite of which the peridotites form the base. Importantly, we have found no field evidence to suggest the peridotites are part of an ophiolite; the widespread lherzolites, in any case, are not typical of an ophiolite peridotite (cf. Boudier and Nicolas, 1985), and apart from rare dunite and harzburgite and a few gabbro dykes, no components of an ophiolite sequence have been found on Seram or Ambon. There are certainly no voluminous gabbros or sheeted dyke complexes, nor is there evidence in sediments for erosion of ophiolitic rocks. Pillow basalts are confined to Tanjung Nusanive (Latimor) and Kelang (K-Ar age of 7.6 $\pm 1.4 \mathrm{Ma}$; Beckinsale and Nakapadungrat, 1978) where they do not structurally overlie peridotites.

\subsubsection{Nature of the peridotite-gneiss contact}

The northern half of the Kaibobo Peninsula consists of schists, amphibolites, and gneisses assigned to the Taunusa
Complex by Tjokrosapoetro et al. (1993b). The nature of the contact between these metamorphic units and the ultramafic complex to their south has previously been described as a SSW-dipping thrust above which the ultramafic complex was thought to have been obducted (e.g. Linthout et al., 1989, 1996; Linthout and Helmers, 1994; Monnier et al., 2003). In this scenario, the ultramafic complex was therefore considered as the base of an ophiolite with the schists and gniesses thought to represent its metamorphic sole, and the cordierite granite produced through sub-ophiolite anatexis before being emplaced into the over-riding peridotite. However, the contact relations between the so-called ophiolite and its sole have never been described, suggesting that previous authors did not find a place where the contact is exposed. The main line of evidence used by Linthout et al. (1989) to argue for the existence of a metamorphic sole is an increase in metamorphic grade upon approaching the contact; as mentioned in Sect. 2.1, sillimanite-grade gneisses near to the peridotites yield peak metamorphic temperatures of $>700^{\circ} \mathrm{C}$, compared with $\sim 600^{\circ} \mathrm{C}$ for typical Tehoru Formation metamorphic rocks on Seram, but no evidence was presented to support the interpretation of the peridotite-gneiss contact as a south-dipping thrust.

Fortunately, we found a small exposure of this important contact in an unnamed stream which flows into Teluk Latal $\left(128.200^{\circ} \mathrm{E}, 3.182^{\circ} \mathrm{S}\right)$. The contact is revealed to be a complex shear zone including multiple parallel-trending faults (oriented $120-300^{\circ}$ ) which separate mantle peridotites from a hornblende granodiorite diatexite. The hornblende granodiorite is identical to the rocks adjacent to the peridotitegneiss contact present at other localities (best exhibited on the Hoamoal Peninsula - see Sect. 3.2) that are shown to be the ultimate product of migmatisation of the Taunusa Complex schists and amphibolites.

In addition to finding an exposure of this important contact, its trace across the steep topography of the Kaibobo Peninsula is well-constrained from our mapping (Fig. 5); structure contours reveal the contact to be a planar feature striking at $300^{\circ}$ with a $20^{\circ}$ dip to the NNE (Fig. 6). Furthermore, peridotites that underlie the detachment are sheared and faulted parallel to the inferred fault plane (Fig. 7i), 

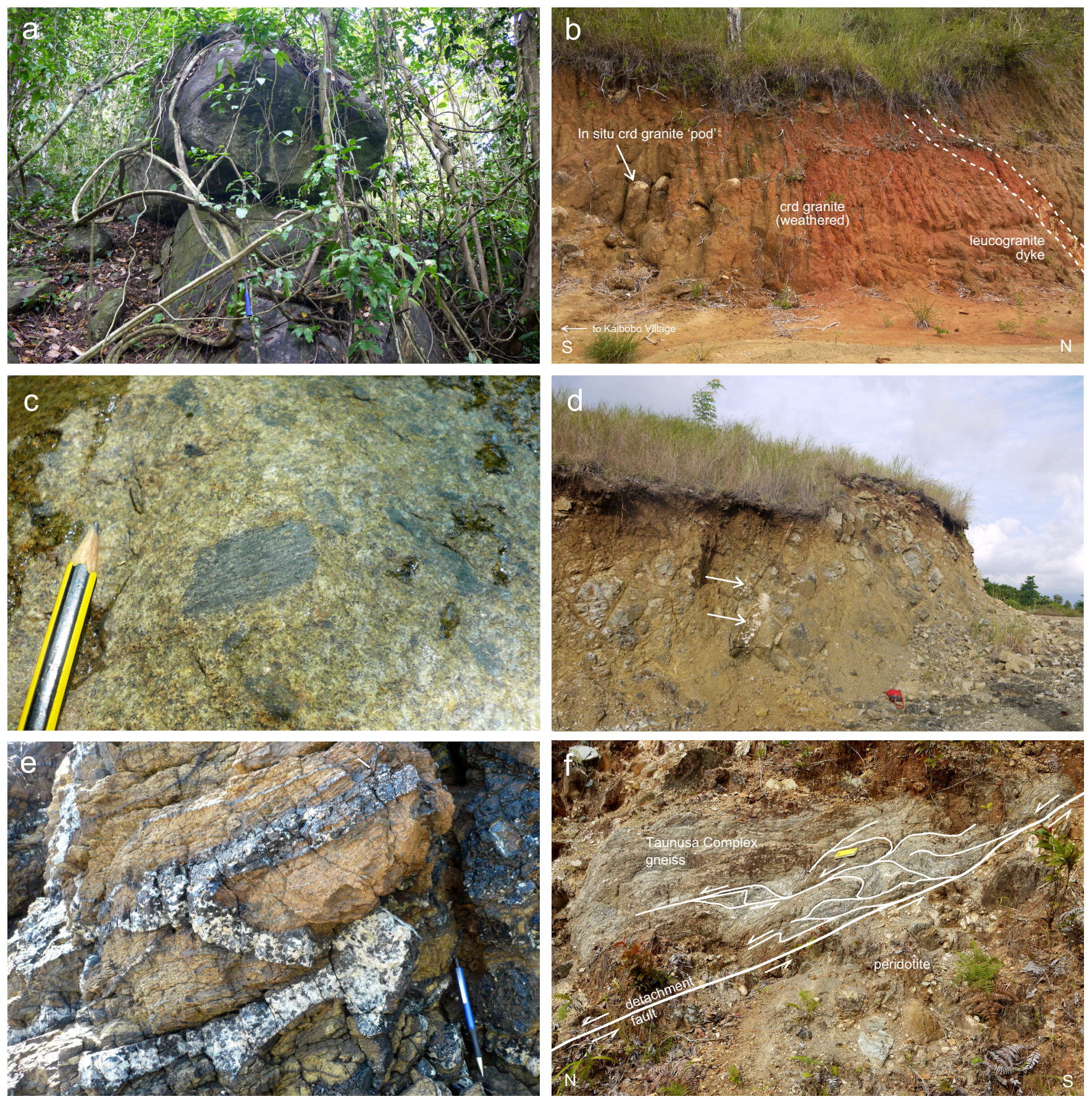

Fig. 7. Field relations on the Kaibobo Peninsula. (a) Typical cordierite granite boulder of the North Kaibobo Granite (128.1740 ${ }^{\circ}$, $3.1882^{\circ} \mathrm{S}$ ); (b) Pods of in situ cordierite granite (left) which have escaped the weathering that has affected the rest of the exposure. A leucogranite dyke (right) has intruded these weathered cordierite granites $\left(128.1787^{\circ} \mathrm{E}, 3.2005^{\circ} \mathrm{S}\right)$; (c) Sillimanite-spinel-corundumcordierite schlieren within a cordierite granite boulder, South Kaibobo Granite $\left(128.2004^{\circ} \mathrm{E}, 3.1833^{\circ} \mathrm{S}\right)$; (d) Leucogranite dykes (marked by arrows) within serpentinised peridotites adjacent to the granite-peridotite contact, South Kaibobo Granite $\left(128.1734^{\circ} \mathrm{E}, 3.2102^{\circ} \mathrm{S}\right) ;(\mathbf{e})$ Peridotite on Tanjung Sisi net-veined by pegmatitic hornblende granodiorite $\left(128.1596^{\circ} \mathrm{E}, 3.1592^{\circ} \mathrm{S}\right)$; (f) Detachment fault exposed in a roadcut (inland from the Kaibobo Peninsula between Piru and Waisarisa) separating Taunusa Complex gneiss and diatexite (above) from exhumed peridotites (below). A top-to-the-north shear sense is indicated by the folding in the gneisses in response to southward exhumation of the peridotite beneath the detachment $\left(128.2444^{\circ} \mathrm{E}, 3.1231^{\circ} \mathrm{S}\right)$. 

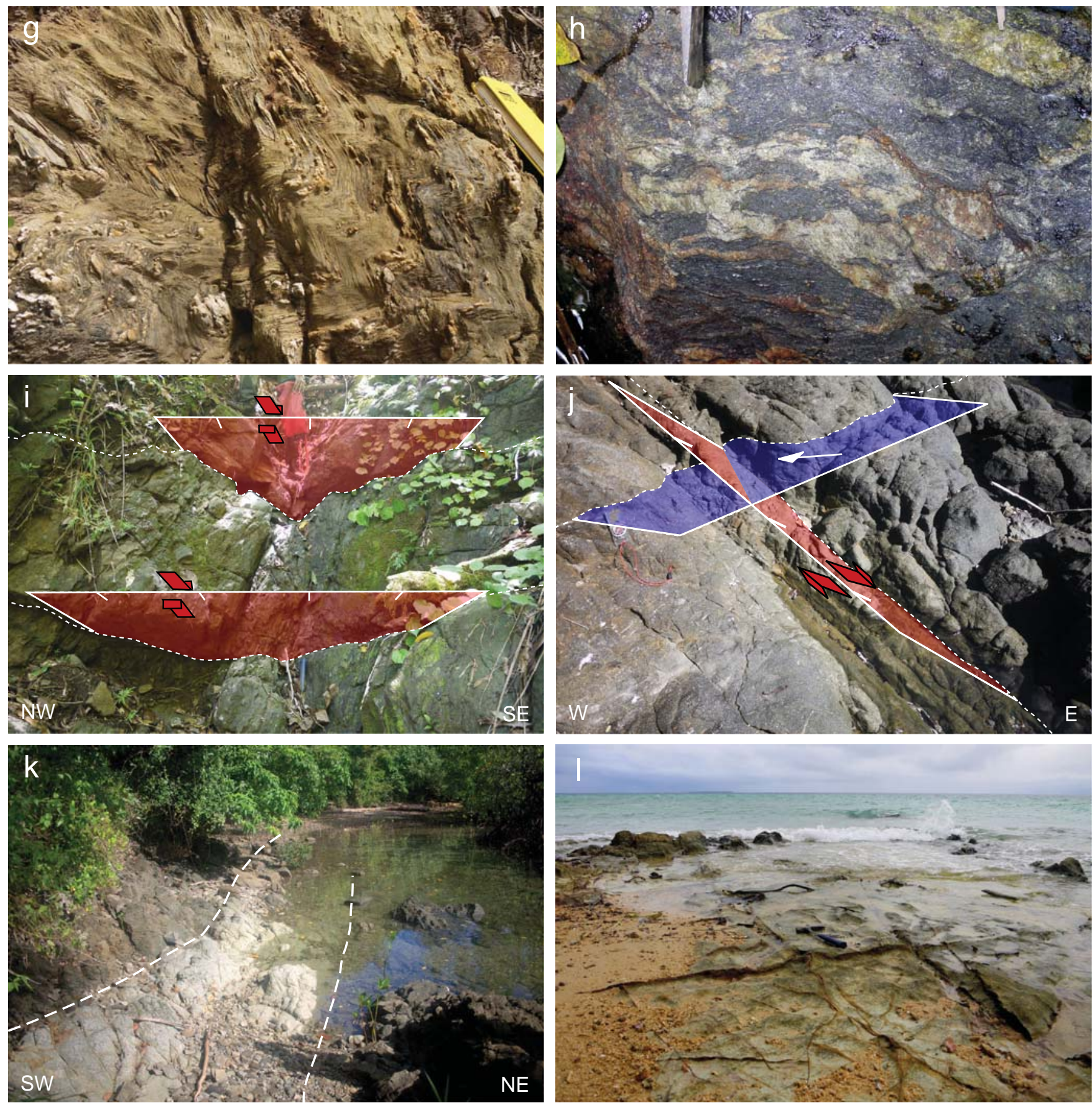

Fig. 7. Continued. Field relations on the Kaibobo Peninsula. (g) Tightly folded mica schists of the Tehoru Formation on Tanjung Tutunaten $\left(128.1717^{\circ} \mathrm{E}, 3.1402^{\circ} \mathrm{S}\right)$; (h) Metatexites of the Taunusa Complex metamorphic-migmatitic overprint $\left(128.1924^{\circ} \mathrm{E}, 3.1708^{\circ} \mathrm{S}\right)$; (i) Faults within peridotites lying just beneath and oriented parallel to the Kaibobo Detachment $\left(128.1765^{\circ} \mathrm{E}, 3.1755^{\circ} \mathrm{S}\right)$; (j) $\mathrm{Mylonitised}$ cordierite granites of the Tanjung Motianai shear zone. Mylonitic foliation (blue plane; 232/28N) and lineation (white arrow; 12/258) are indicated, which have been cut by steep normal faults (red plane; 300/55N) that have been exploited by haematite mineralisation $\left(128.2024^{\circ} \mathrm{E}, 3.2173^{\circ} \mathrm{S}\right)$; (k) Gabbro dyke intruded through mylonitised granite on Tanjung Motianai $\left(128.2022^{\circ} \mathrm{E}, 3.2172^{\circ} \mathrm{S}\right)$; (l) $\mathrm{Criss}^{-}$ crossing haematite veins through sandstone on Tanjung Totuhur, Pulau Babi $\left(128.1553^{\circ} \mathrm{E}, 3.2313^{\circ} \mathrm{S}\right)$.

demonstrating that the shear zone associated with the detachment fault is a major lithospheric feature. The peridotitegneiss contact therefore does not represent a south-dipping thrust as suggested by Linthout et al. (1996) in order to explain their hypothesised north-directed obduction of the "ophiolite" peridotites. Instead, the fault is revealed to be a 
low-angle $\left(<20^{\circ}\right)$ NNE-dipping normal fault we shall refer to as the Kaibobo Detachment which bounds mantle peridotites beneath the Taunusa metamorphic complex and has facilitated their exhumation. This same relationship is also exposed inland from the Kaibobo Peninsula (in a roadcut at $128.244^{\circ}$ E, $3.123^{\circ} \mathrm{S}$; Fig. 7f) where a shear zone of Taunusa Complex gneisses overlie serpentinised peridotites above a different but equivalent low-angle extensional detachment. At this locality, fold geometries and fault patterns in the overlying gneiss clearly indicate top-to-the-N shear in response to southward exhumation of the peridotites beneath the fault.

Comprising the hanging wall adjacent to the peridotite, sillimanite-bearing gneisses and metatexite migmatites (Fig. 7h) have developed after progressive metamorphism and migmatisation of the mica schists and phyllites that crop out several km further north from the contact (Fig. $7 \mathrm{~g}$ ). The metatexites are often intensely mylonitised and have pronounced shear banding. In many instances, biotites and white micas have developed fish-type geometries. Fibrolite is often well-developed along shear bands that cross-cut older biotite-defined fabrics, confirming the shear-zone operated at $>500^{\circ} \mathrm{C}$. Garnet porphyroblasts are abundant and predate mylonitisation.

The contact is evidently a high-temperature shear zone in which the hanging wall has experienced increasing migmatisation, rather than it representing a telescoped sub-ophiolite metamorphic sole as proposed by Linthout et al. (1989) and Linthout and Helmers (1994). Furthermore, there is no evidence that the cordierite granites were generated by anatexis within this shear zone; as previously discussed, the hornblende granodiorite diatexites that have formed adjacent to the peridotite contact from partial melting of Taunusa Complex amphibolites cannot be the source of the cordierite granites due to their markedly different composition and the lack of cordierite and garnet phenocrysts, biotite, and sill-sp-crd schlieren. Furthermore, the localised nature of the anatexis could not account for the high-volume melts that would be required to feed the Kaibobo Granites according to the Seram Ophiolite hypothesis.

From our mapping, the North Kaibobo Granite is shown to be truncated by the Kaibobo Detachment, and therefore the peridotites and granites must have been exhumed as a single tectonic unit which was juxtaposed against the hanging wall metamorphics. Exhumation of this unit before it had cooled from high temperature (i.e. still $>700^{\circ} \mathrm{C}$ ) would explain the high-temperature metamorphic overprint of the hanging wall as identified by Linthout et al. (1989) and would also account for the generation of the hornblende granodiorites by hanging wall diatexis. Although we do not support the ophiolite model of Linthout and Helmers (1994), we do share the view that the Taunusa Complex represents a metamorphic/migmatitic overprint of the previously metamorphosed Tehoru Complex rocks. Furthermore, the 5.4-6.0 Ma Ar- $\mathrm{Ar}$ ages obtained by Linthout et al. (1996) for micas from the sheared Taunusa Complex gneisses still may provide a reli- able date for the juxtaposition of hot peridotite and the development of the associated high-temperature shear zone, irrespective of whether or not the ultramafic rocks are interpreted to comprise exhumed mantle or the base of an ophiolite.

\subsubsection{The southern Kaibobo shear zone}

On Tanjung Motianai (SE Kaibobo Peninsula), mylonitised cordierite granites are overlain by sheared amphibolites, which in turn are overlain by the ultramafic complex (Fig. 8). We infer the units to be separated by low-angle normal faults that strike ENE-WSW. The granite mylonite is mineralogically identical to the other Kaibobo Granites and of course contains the ubiquitous crd-sill-sp schlieren. Its mylonitic foliation dips at $\sim 30^{\circ}$ to the NW, and biotite fish help to define an S-C fabric indicating top-to-the-NE shear along a $10 / 245^{\circ}$ lineation. The fabrics are cut by numerous younger high-angle faults, which strike at $300^{\circ}$ (Fig. $7 \mathrm{j}$ ), that have been exploited by haematite mineralisation. The amphibolites are very different in appearance to those which are members of the Taunusa Complex further to the north and comprise over $90 \mathrm{vol} \% \sigma$-type hornblende phenocrysts of varying size (up to $5 \mathrm{~mm}$ ) which define a prominent $S-\mathrm{C}^{\prime}$ fabric. The amphibolites are bordered by peridotites to their north along an intensely serpentinised faulted contact across which a network of wide serpentinite and kaolinite veins have intruded both lithologies. The amphibolites therefore appear likely to have formed through metamorphism and shearing of mafic-ultramafic rocks present in the peridotite complex which overlaid the granites during operation of the shear zone, and so are unrelated to the Taunusa Complex. We therefore conclude that the Tanjung Motianai granite mylonites and overriding amphibolites are part of an extensional shear zone which has developed parallel to and structurally beneath the Kaibobo Detachment that has operated within the high-T footwall unit (Fig. 6); the orientation of the mylonitic lineation and the strike of the steeper mineralised faults are respectively normal and parallel to the Kaibobo Detachment. An undeformed gabbro dyke has intruded the mylonitised granites by the eastern shore of the peninsula (Fig. 7k).

Pulau Babi and the southernmost Kaibobo Peninsula are made of carbonates and sandstones which have been correlated with the Triassic Asinipe Limestones of the Manusela Mountains (Martini et al., 2004) and U-Pb dating of detrital zircons from these sandstones have yielded some Triassic ages (Hall and Sevastjanova, 2012; Sevastjanova et al., 2012). From our mapping, these sedimentary units are shown to be separated from the peridotites to their north by a high-angle fault with roughly the same strike as the Kaibobo Detachment. A surprising feature is the occurrence of haematite veins, similar to those on Tanjung Motianai, which criss-cross sandstones in the foreshore at Tanjung Totuhur (Fig. 71). This phenomena is reminiscent of other documented examples of mineralisation within extensional 


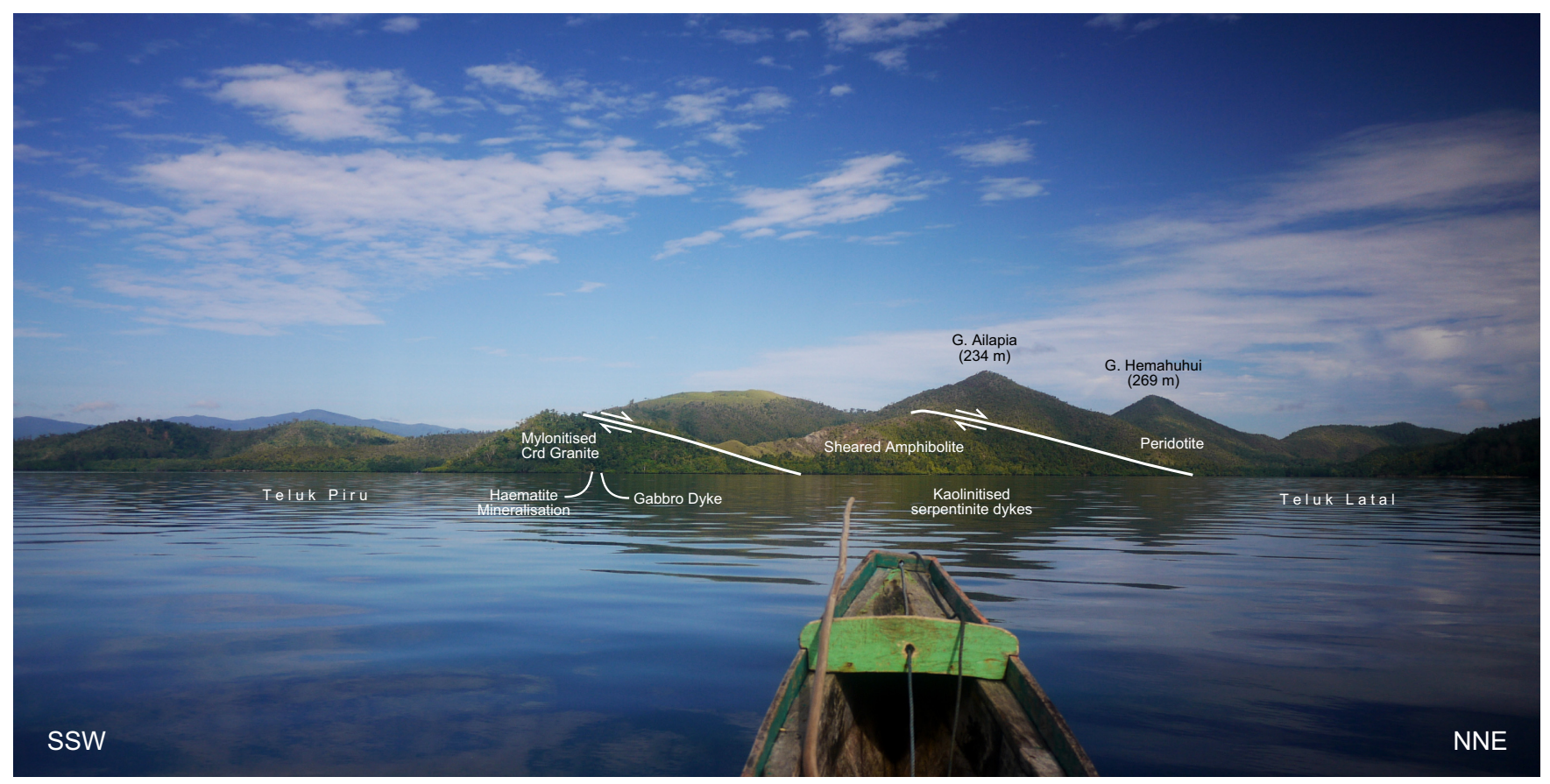

Fig. 8. Tanjung Motianai and the South Kaibobo Shear Zone, viewed from the SE. Mylonitised granites are overlain by sheared amphibolites. The contact between the amphibolites and peridotites is intensely serpentinised and numerous serpentinite dykes and associated kaolinites are present. The granite mylonite is intruded by a gabbro dyke and several haematite veins.

detachment zones in core-complex-type settings (e.g. Long, 1992; Seidel et al., 2005; Smith et al., 2010).

\subsection{Hoamoal Peninsula}

The geology of the northeast Hoamoal Peninsula is in many ways similar to the Kaibobo Peninsula; the ultramafic complex and basement schists are exposed in close association allowing their contact relations to be investigated. This region was left blank on the map by Valk (1945) and so Tjokrosapoetro et al. (1993a) have provided the only published map of the region. Our map is presented in Fig. 9.

\subsubsection{Nature of the peridotite-gneiss contact}

The metamorphic basement of the NE Hoamoal Peninsula comprises mainly upper-greenschist to lower-amphibolite facies metapelites (mica-schists and garnet-mica-schists, dominantly) with occasional intercalated metabasic amphibolites. Kyanite-staurolite-garnet schists present in float indicate higher grade metamorphics are present in the mountainous interior, although were never observed in situ. Lower grade rocks are phyllitic, micaceous, and fine-grained. The rocks show widespread deformation, although no large-scale folding was observed; axial-planar cleavages are often developed in relation to minor folds. Quartz veining and quartz lenses are common throughout. Serpentinised peridotites are widespread in this region, and are very similar to those on the Kaibobo Peninsula and Latimor. Leucogranite dykes are ab- sent because these peridotites do not contain cordierite granite bodies.

Traverses up several streams which cross the peridotitegneiss contact showed field relations very similar to those described from the Kaibobo Peninsula (see map, Fig. 9). Upon approaching the contact with the peridotites, a progressive increase in migmatisation of the metamorphics is very apparent. At approximately 500 to $800 \mathrm{~m}$ horizontal distance from the peridotite margin, there is a marked change from low- to medium-grade phyllites and mica-schists of the type that comprise the majority of the Tehoru Formation (as mapped and defined by Tjokrosapoetro et al., 1993a), to partially recrystallised and quartz-veined hornfelses. Travelling further towards the contact with the ultramafic body, mafic-felsic segregations within the mica schists and intercalated amphibolites become increasingly more pronounced until gneissose fabrics are well-developed (Fig. 10a, b). Then, a progressive migmatisation of the gneisses is evident. Initially, metatexite migmatites that are host only to narrow veins of finely crystalline leucosome crop out, but after more advanced migmatisation, diatexites were evidently produced containing neosomes that have merged and coalesced to represent a high-volume interstitial melt between gneissose paleosomes (Fig. 10c, d). In all instances we observed, the metamorphic rocks closest to the peridotite are amphibolites (by chance?), and so the neosomes of the resulting migmatites have hornblende-rich granodioritic compositions. Migmatites immediately adjacent to the peridotite 


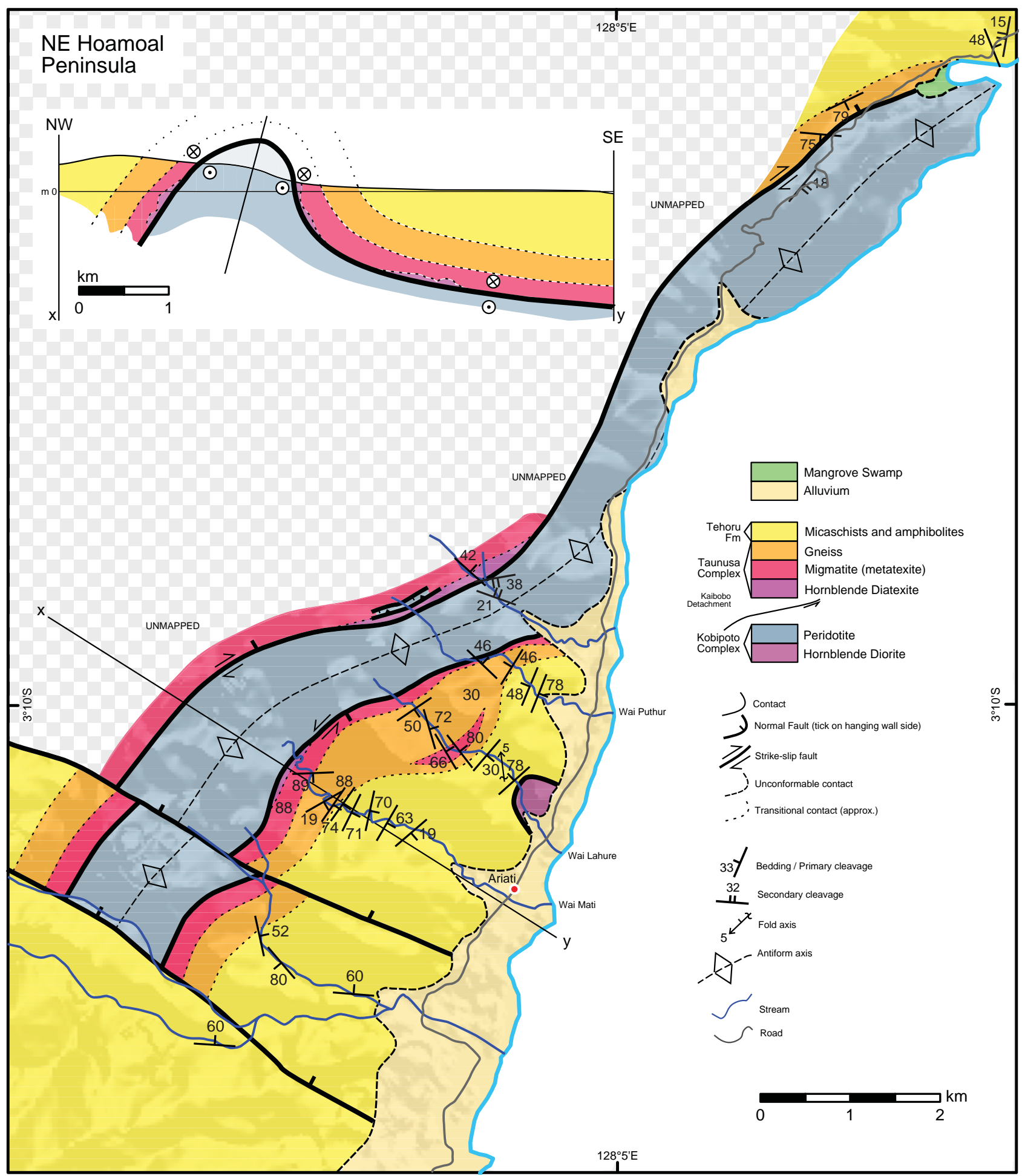

Fig. 9. Geological map of the NW Hoamoal Peninsula. Cross section Y-Y' (top-left) is drawn across profile $Y-Y^{\prime}$ indicated on the map and has no vertical exaggeration. The chequered area has not been mapped. See Fig. 3 for map location.

contact feature this hornblende-rich neosome as the most voluminous component of the rock within which numerous large gneissose schollen are suspended (Fig. 10e, f).
We shall refer to this rock as "hornblende diatexite" because it has evidently formed by diatexis of Tehoru Formation amphibolites. The hornblende diatexite is typically 

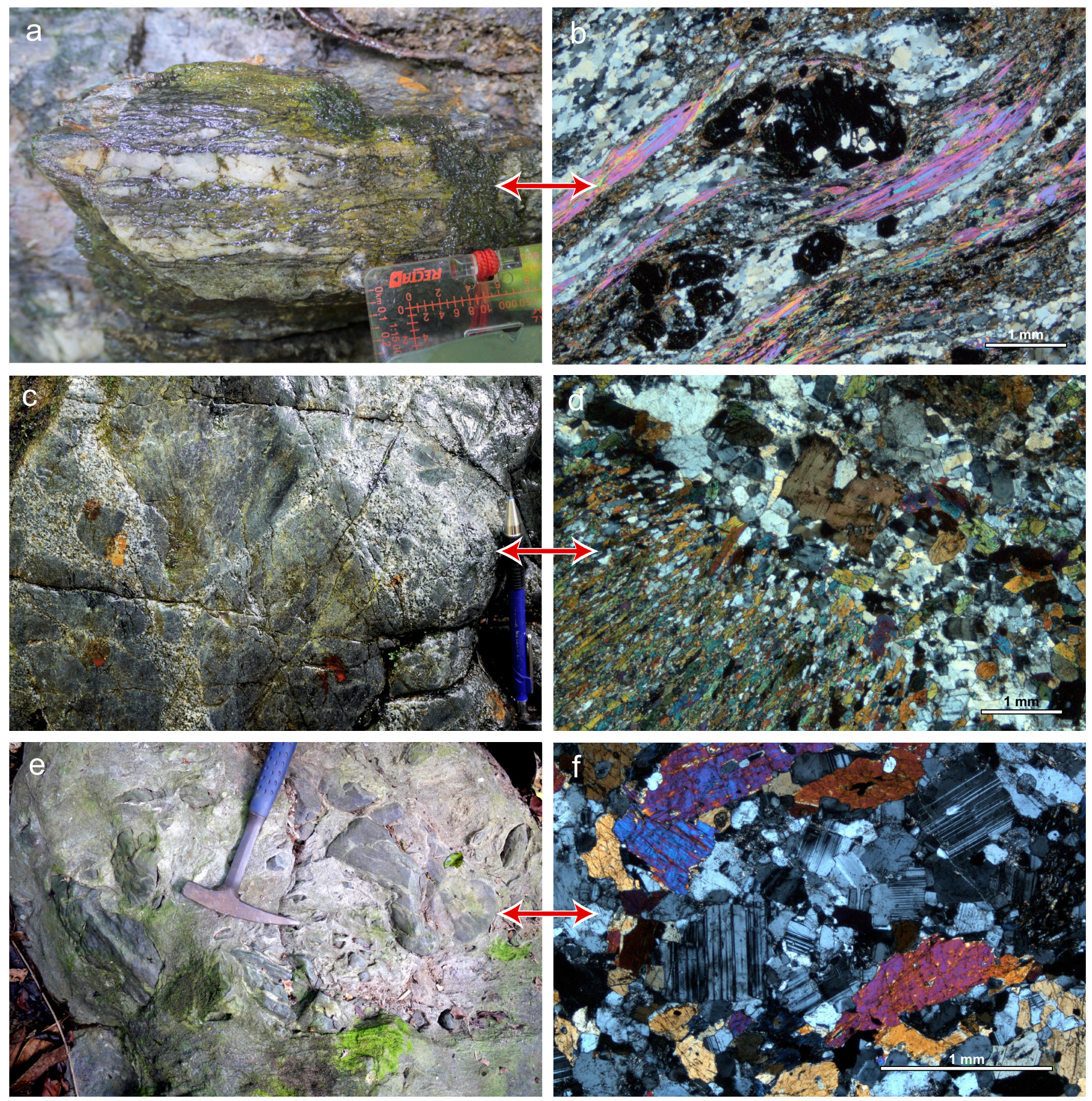

Fig. 10. Progressive migmatisation of the Tehoru Formation to form the Taunusa Complex in the NE Hoamoal Peninsula. (a, b) Tehoru Formation garnet mica schist in which quartz and mica segregation has resulted in development of a gneissose texture $\left(128.0585^{\circ} \mathrm{E}, 3.1774^{\circ} \mathrm{S}\right)$; (c, d) Migmatite after amphibolite: hornblende granodioritic neosome has formed an interconnected melt between amphibolite mesosomes $\left(128.1787^{\circ} \mathrm{E}, 3.2005^{\circ} \mathrm{S}\right)$; (e, f) Hornblende granodiorite diatexite containing large schollen of amphibolite mesosome, located immediately adjacent to the peridotites $\left(128.0699^{\circ} \mathrm{E}, 3.1533^{\circ} \mathrm{S}\right)$.

more coarsely crystalline than the less voluminous interstitial melts within the metatexites (compare Figs. 10d and f). Also, these hornblende diatexites are notably more voluminous than on the Kaibobo Peninsula where only metatexites are well-developed. As concluded for the Kaibobo Peninsula, the migmatisation and anatexis is interpreted as due to heating by the adjacent perioditite body.

The peridotites closest to the contact are intensely serpentinised, and those further from the contact are less serpentinised and blocky in outcrop. The peridotite contact is not 
exposed in the streams we explored, but its location has in most instances been constrained to within a few tens of metres (see map in Fig. 9).

As shown by the geological map and cross section (Fig. 9), the peridotite forms the core of a NE-SW trending antiform that has subsequently been cut by high-angle NW-SE trending faults to the south. The faulted contact between the peridotite and overlying migmatised Taunusa Complex rocks is therefore tightly arched. Steeply dipping mylonitic foliations within gneisses and migmatites of the southeastern fold limb, which strike parallel to the antiform's fold axis, typically indicate a left-lateral strike-slip shear sense indicating a relative southwestward motion of the peridotite beneath the contact. In other words, the peridotite "core" of the antiform has slid out to the SW beneath the overlying metamorphic rocks. The antiform is interpreted to represent a kind of sheath fold formed within a low-angle fault plane that has caused southwestward exhumation of the peridotite beheath the metamorphic hanging wall. Alternatively, the folding occurred after the operation of a planar detachment fault. Either way, the relative motion between the hanging wall (comprising the metamorphic complex) and footwall (comprising the peridotites) at this locality is identical to that inferred from across the nearby Kaibobo Detachment. These faults are considered to have formed during the same tectonic episode and might even be connected or coupled beneath Piru Bay.

\subsubsection{Faulting in the southern Hoamoal Peninsula}

A steep dirt track from the village of Luhu connects the east and west coasts of the southern Hoamoal Peninsula and crosses three NW-SE trending faults. The southernmost fault has upthrown peridotite to its southwest against Taunusa Complex rocks to its northeast which has resulted in a similar high-temperature contact relation to that seen in the north of the peninsula. The northernmost two faults bound a peridotite graben and have caused uplift of limestone terraces to the south. In this instance, peridotite is in contact with basement schists, but the high-temperature contact relations are not present here; it appears these two faults postdate the exhumation of hot peridotite. The strike of these faults (about $300^{\circ}$ ) is similar to the peridotite-basement contact on the Kaibobo Peninsula, and to the steep normal faults inferred in northern Hoamoal. A single boulder of cordierite-granite was found exposed in the track, within peridotite breccias, just south of the southernmost fault.

In the Air Besar (river north of Luhu), monotonous garnetmica schists are exposed. The schists are highly deformed with variable strike over the river section traversed. Nevertheless, examples of top-to-the-NE shear are present that have possibly formed in response to the same NNE-SSW extensional event as identified on the NE Hoamoal and Kaibobo peninsulas.

\subsection{The Wallace Mountains and Teluk Elaputih}

The Wallace Mountains, located in southwest Seram, reach their highest point at Gunung Toplana $(1331 \mathrm{~m})$. The mountains have previously been mapped as mica schists of the Taunusa Complex which include peridotites in their eastern region (Tjokrosapoetro et al., 1993a). Outcrop proved difficult to access because of the wide skirt of densely forested alluvium between the coastal road and the foot of the mountains. In the Wai Wari, to the east of the mountains, in situ peridotites crop out and there are abundant peridotite, cordierite granite, gabbro, and schist boulders present in the float. The cordierite granites contain a higher percentage of larger gneissose schollen (up to $20 \mathrm{~cm}$ across) than seen elsewhere on the island aside from the Kobipoto Mountains.

Explored from the coast of Teluk Elaputih, the long Wai Mala drains from deep in the central Seram mountains and crosses the inferred trace of the Kawa Fault. AudleyCharles et al. (1979, p. 559) reported boulders of high-grade "garnet-pyroxene granulite (metagabbro)" from the float of this river, and we have found examples of similar Cpx-Grt$\mathrm{Hbl}$ gneisses from the same location. This demonstrates that high grade (upper-amphibolite to granulite facies) rocks crop out in central-western Seram. Superficially, these rocks appear similar to those present in the Kobipoto Mountains, as described later (Sect. 3.5), and may indicate that an association exists between Kobipoto Complex and Taunusa/Tehoru Complex rocks in the interior of mid-west Seram.

\subsection{Kawa Shear Zone}

A major strike-slip fault with a prominent topographic expression, referred to here as the Kawa Fault after the river which runs down much of its length, runs ESE-WNW to the south of the Manusela Mountains of central Seram (Fig. 3b). The Kawa Fault and associated fault splays form a $\sim 2 \mathrm{~km}$ wide shear zone which is crossed by the Trans-Seram Highway in the interior of central Seram. A geological map (Fig. 11) and a cross section (Fig. 12) through the shear zone in this region have been constructed from a series of stream traverses made accessible by the road.

Several parallel-trending strike-slip faults have been identified in this region. The southernmost of these is interpreted as the main splay of the Kawa Fault and bounds garnet mica schists of the metamorphic basement against fault gouges and breccias of the Kawa Shear Zone to the north. Mylonitic fabrics, which overprint older folds and cleavages, are increasingly more pronounced moving northwards towards the Kawa Fault. Tehoru Formation garnet-mica schists (and occasional amphibolites) south of the fault zone have been deformed into a tight anticline, and schists adjacent to the fault have been intensely folded on a smaller scale. Minor extensional faults and fractures appear to post-date shearing and cross-cut two developed cleavages (from original bedding and a cleavage axial planar to folding). Interbedded slates 


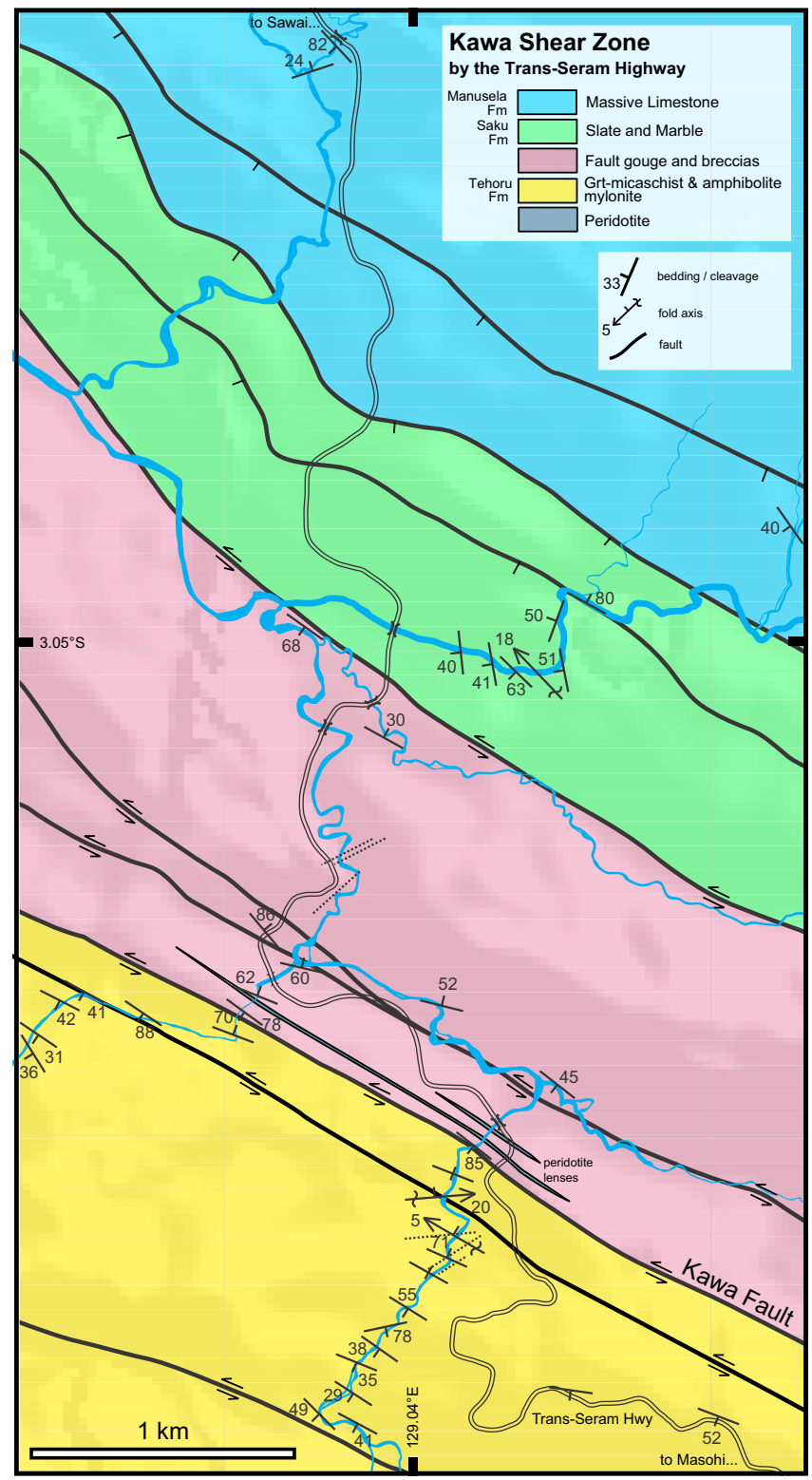

Fig. 11. Geological map of the Kawa Fault Zone in the vicinity of the Trans-Seram Highway. See Fig. 12 for cross section drawn perpendicular to the strike of the faults. See Fig. 3 for location of this map in central Seram. Note the thin slivers of peridotite immediately north of the Kawa Fault. The short dotted lines represent minor normal faults exposed in the streams.

and marbles of the Saku Formation form an anticline to the north, which is faulted to its north against massive limestones of the Manusela Mountain range.

The shear zone was also studied north of the village of Tehoru on the coast of Teluk Taluti in central-southern Seram. At this locality, mylonites containing $\mathrm{cm}$-sized garnet porphyroblasts strike $130^{\circ}$ (parallel to the coastline) with variable dip, maybe formed parallel to a braid of the Kawa
Fault which seems from ASTER imagery to branch NW of the Wai Kawa estuary.

The overall shear sense of the fault is not immediately obvious due to the presence of both left- and right-lateral kinematic indicators (small-scale folds, quartz sigmoids, and $\sigma$ - and $\delta$-type garnet porphyroblasts). These features have formed in the different limbs of larger-scale isoclinal fold structures which themselves cannot be easily be discerned from the limited outcrop. For example, parasitic S- and Zfolds are clearly exhibited in coastal outcrop north of Tehoru within in the limbs of larger isoclinal folds whose axial planes lie parallel to a splay of the Kawa Fault. We therefore do not share the confidence of Linthout et al. (1991) that there is unambiguous evidence for a right-lateral shear zone despite clear examples of right-lateral kinematic indicators being present. As a further example, off the Trans-Seram Highway, folded quartz veins which indicate right-lateral shear are found downstream from $\sigma$-type garnet porphyroblasts which uniformly indicate an opposite left-lateral shear-sense. Fault gouges and breccias in the central region of the shear zone are aligned to the $300^{\circ}$ strike of the faults, but unfortunately no convincing shear-sense indicators could be found due to the intense brecciation, nor was the rock well enough consolidated to be sampled for microstructural analysis. The fault gouges and breccias are cut by small normal faults with NESW strikes which show minor offsets. These faults seem to be related to larger normal faults inferred from DEM interpretation (Sect. 4) which share the same orientation and offset the strike-slip faults in western-central Seram.

The Kawa Fault is undoubtedly a major lithospheric feature which has played an important role in the recent tectonic evolution of Seram and the Banda Arc. It has previously been suggested that the fault operated within an antithetic shear zone that facilitated a significant $\left(>90^{\circ}\right)$ anticlockwise rotation of the island (Linthout et al., 1991), based on its interpretation as a major dextral strike-slip feature (Linthout et al., 1989) and a palaeomagnetic study which first proposed the rotation (Haile, 1978). The palaeomagnetic results that have been used to suggest large regional rotations were originally described by (Haile, 1978, p. 191) as "only of a reconnaissance nature" and could simply record local tectonic rotations. Furthermore, it has not been explained how the Kawa Fault and other parallel-trending strike-slip faults in central Seram relate to the low-angle detachment faults identified on the Kaibobo and Hoamoal peninsulas of western Seram.

However, we have now found a previously undocumented link between the two regions - there is a chain of boudinaged lenses of serpentinised peridotites which are bounded by brecciated mylonites and fault gouges immediately to the north of the Kawa Fault. The serpentinite lenses lie parallel to the $300^{\circ}$ strike of the Kawa Fault and crop out in two separate streams (at a $1 \mathrm{~km}$ separation) in the area mapped, and lie on the same strike (Fig. 13c, d). The discovery of peridotite in the fault zone suggests that at some time in its history the Kawa fault may have operated with a dominantly 


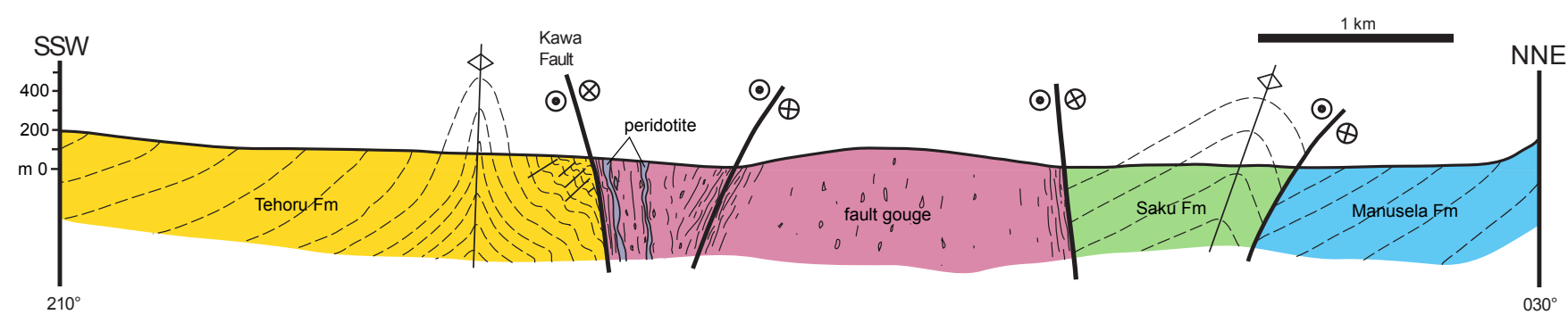

Fig. 12. Cross section through the Kawa Fault Zone in the vicinity of the Trans-Seram Highway as mapped in Fig. 11.
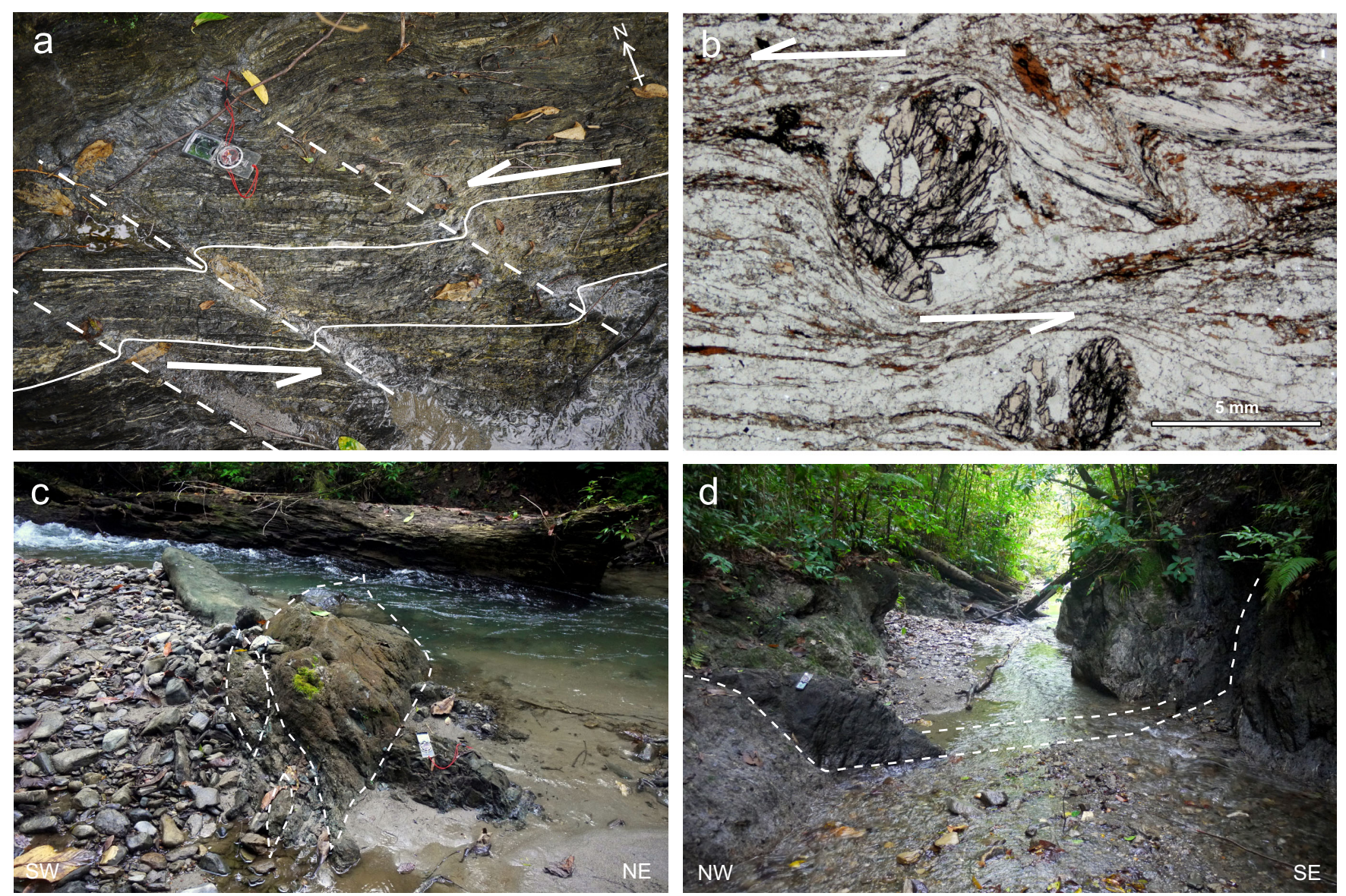

Fig. 13. The Kawa Shear Zone. (a) Left-lateral shear banding in garnet mica schists south of the Kawa Fault $\left(129.0408^{\circ} \mathrm{E}, 3.0689^{\circ} \mathrm{S}\right)$; (b) $\sigma$-type garnet porphyroblasts record left-lateral shear in the garnet mica schists south of the Kawa Fault $\left(129.0394^{\circ} \mathrm{E}, 3.0727^{\circ} \mathrm{S}\right) ;(\mathbf{c}, \mathbf{d})$ Peridotite boudins within fault gouges and breccias just north of the inferred trace of the Kawa Fault are aligned to the $120-300^{\circ}$ strike of the fault zone $\left(129.0423^{\circ} \mathrm{E}, 3.0666^{\circ} \mathrm{S}\right.$ and $129.0336^{\circ} \mathrm{E}, 3.0622^{\circ} \mathrm{S}$, respectively).

dip-slip motion to have exhumed the upper mantle in a similar to fashion to that apparent in western Seram. The peridotites have evidently been sheared and boudinaged after a more recent strike-slip episode which has affected only the central parts of the island. It should yet again be pointed out that the Kawa Fault and the Kaibobo Detachment have the same $120-300^{\circ}$ strike.

\subsection{Kobipoto Mountains}

The Kobipoto Mountains are the only place north of the Kawa Fault Zone, aside from a region near Gunung Langget in SE Seram, where peridotites, granites, and (very) highgrade metamorphic rocks are present. The mountains are bordered on all sides by the Mesozoic Kanikeh Formation. Audley-Charles et al. (1979) proposed that this "Kobipoto Complex" represents an overthrust allochthon of 
Precambrian Australian basement. In contrast, the mountains have more recently been mapped by Tjokrosapoetro et al. (1993a) as further exposure of the Permian Taunusa Complex. Unfortunately, there is no road or boat access to the region and exploration on foot is slow, difficult, and dangerous. We walked to the northwestern part of the complex via the small villages of Huaulu and Roho, and traversed sections of the Wai Sae, Wai Sapolewa, and Wai Tuh river gorges. A new geological map of the western Kobipoto Mountains is presented in Fig. 14 compiled from the fieldwork described here, from unpublished field notes made by M. Norvick during the 1975 Seram Expedition (Audley-Charles et al., 1979), from observations made by Rutten and Hotz in 1918 (Germeraad, 1946), and from faults inferred from ASTER DEM interpretation. A sketch cross section through the western Kobipoto Mountains is presented in Fig. 15.

\subsubsection{Wai Sai}

We entered the Wai Sai to the SE of Roho village. Steeply dipping beds of dark grey Kanikeh Formation siltstones crop out in the upstream section of our traverse (see map, Fig. 14) and massive limestone blocks are present in the downstream section. The contact between these two lithologies is not exposed. Alongside siltstone and limestone float, pebbles of granite, schist, gneiss, and amphibolite are present but not abundant. Audley-Charles et al. (1979) also observed amphibolite pebbles much further upstream near the village of Kanikeh.

\subsubsection{Wai Sapolewa}

The Wai Sapolewa originates near Gunung Binaiya (3027 m) in the Manusela Mountains and crosses the "Central Valley" before exposing a cross section through the entire western Kobipoto Mountains. Audley-Charles et al. (1979) and Rutten and Hotz (Germeraad, 1946) forded the river only near Kanikeh (see map, Fig. 14) and so did not explore its downstream section.

The river exposes an alternation of fault-bounded slices of peridotites with a granulite-facies migmatite complex comprising metatexites and granitic diatexites (or "cordierite granites") interspersed with unmetamorphosed and undeformed dark grey sandstones, siltstones, and mudstones. Breccias of each of these lithologies are commonly present at points where faults have been inferred. The locations of these faults correlate with a set of prominent WNW-ESE-trending topographic lineations revealed by the ASTER DEM, allowing us to extrapolate the trace of the faults encountered crossing the river over a larger area (see map, Fig. 14).

Mylonitised diatexites, which crop out at the confluence of the Wai Sapolewa and Wai Wa, form the footwall beneath grey siltstones and mudstones (Fig. 16a). The outcrop has undergone slight cataclasis by intensive brittle fracturing, although the original structures and orientations are still distin- guishable. The mylonitic foliation $\left(086 / 66^{\circ} \mathrm{S}\right)$ is roughly parallel to the inferred fault plane, and a left-lateral shear component is indicated by $\sigma$-type porphyroblasts. The mylonitised diatexite displays distinct compositional banding between quartzofeldspathic domains and those containing garnet + cordierite (Fig. 16b).

Further upstream, granitic diatexites crop out. They are strikingly similar in appearance to the cordierite granites present in western Seram and Ambon in that they contain cordierite and garnet phenocrysts and abundant schlieren and schollen of sillimanite- and spinel-bearing assemblages. It is important to emphasise this similarity to the western Seram granites, as a link between the two regions is not made apparent by the latest geological maps which show only the Taunusa Complex in the Kobipoto Mountains (Tjokrosapoetro et al., 1993a, b). No previous author has visited both the Kobipoto Mountains and western Seram, although Audley-Charles et al. (1979, p. 560) likened the granitic diatexites from the Wai Tuh to the cordierite granites described from western Seram, and ascribed them both to a "discontinuous belt of cordierite gneiss, granite, and serpentinite" that extends from Buru (van Bemmelen, 1949), through Seram, and around to the Kai Islands in the western outer Banda Arc. However, Audley-Charles et al. (1979) also envisaged the granitic rocks of the Kobipoto Mountains, which have yet to be dated, to belong to an allochthon thrust from the Australian Proterozoic basement. We suggest this is unlikely given their remarkable similarity to the Late Miocene to Pliocene cordierite granites on Ambon and the Kaibobo Peninsula (as dated by Priem et al., 1978; Linthout et al., 1996; Honthaas et al., 1999). De Smet and Barber (1992) instead suggested a Late Palaeozoic age to match the Taunusa and Tehoru complexes, and Bachri (2011) later assumed a Permian age for the exposures in SE Seram. However, we propose that the granulites and granites of the Kobipoto Mountains likely share a Mio-Pliocene age with the cordierite granites of western Seram and we are currently working to test this hypothesis.

The abundant schlieren of granulite-facies residuum present in the cordierite granites points to high-temperature conditions being attained in the Kobipoto Complex. The association of cordierite, sillimanite, and spinel has been described from several well-studied high-temperature (HT) as well as ultrahigh-temperature (UHT) granulite terranes (Harley, 2008; Kelsey, 2008, and references therein) and points to conditions typically $>800^{\circ} \mathrm{C}$ being achieved during peak metamorphism. Furthermore, the volume of cordierite granite present in the Kobipoto Mountains, and indeed across Seram and Ambon, indicates that high degrees of partial melting and melt segregation must have occurred.

A question that now arises is how high-temperature granulite facies conditions were achieved in the Kobipoto Complex and under what tectonic scenario. The answer may lie in the next outcrop to be encountered heading up the Wai Sapolewa - in situ lherzolites (Fig. 16c), which contain 


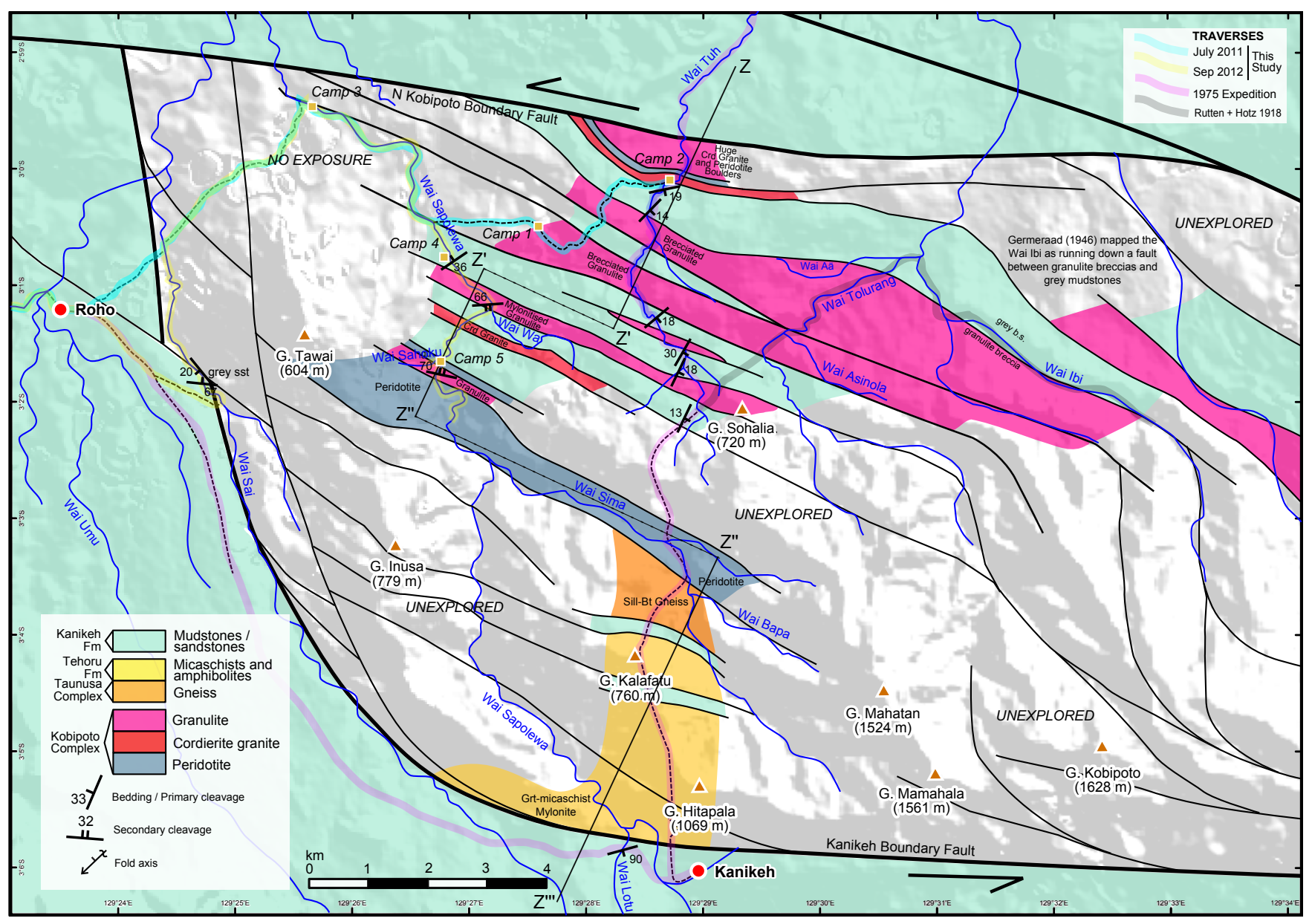

Fig. 14. Geological map of the western Kobipoto Mountains compiled from our traverses through the Wai Sai, Wai Sapolewa, and Wai Tuh river gorges in addition to field observations recorded by Rutten (1918b), Audley-Charles et al. (1979), unpublished field notes by M. Norvick from the 1975 Expedition, and the geological map drawn by Germeraad (1946). The routes traversed through the mountains are highlighted (see key, top-right). Faults have been extrapolated from outcrop observed in stream sections using ASTER data. See Fig. 15 for the cross section along profile $Z-Z^{\prime}-Z^{\prime \prime}-Z^{\prime \prime \prime}$ and see Fig. 3 for location of the map in central Seram.

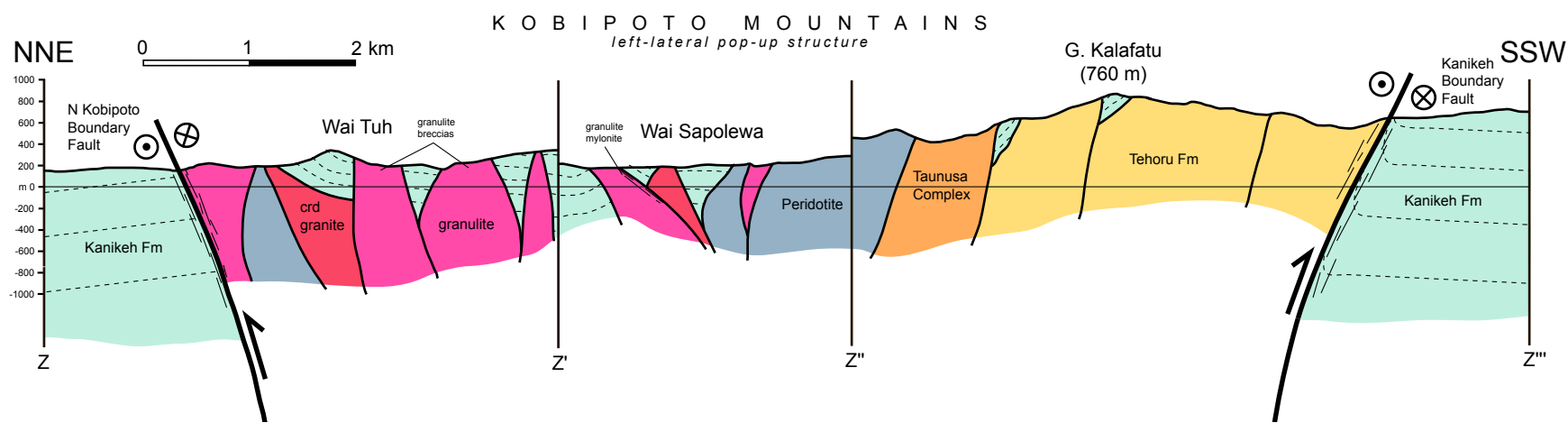

Fig. 15. Semi-schematic cross section through the Kobipoto Mountains following profile $Z-Z^{\prime}-Z^{\prime \prime}-Z^{\prime \prime \prime}$ as shown on the geological map in Fig. 14. All marked faults are interpreted to have had dominantly left-lateral strike-slip senses of motion that have exhumed the Kobipoto and Taunusa/Tehoru Complex rocks within the Kobipoto Mountains positive flower structure. 

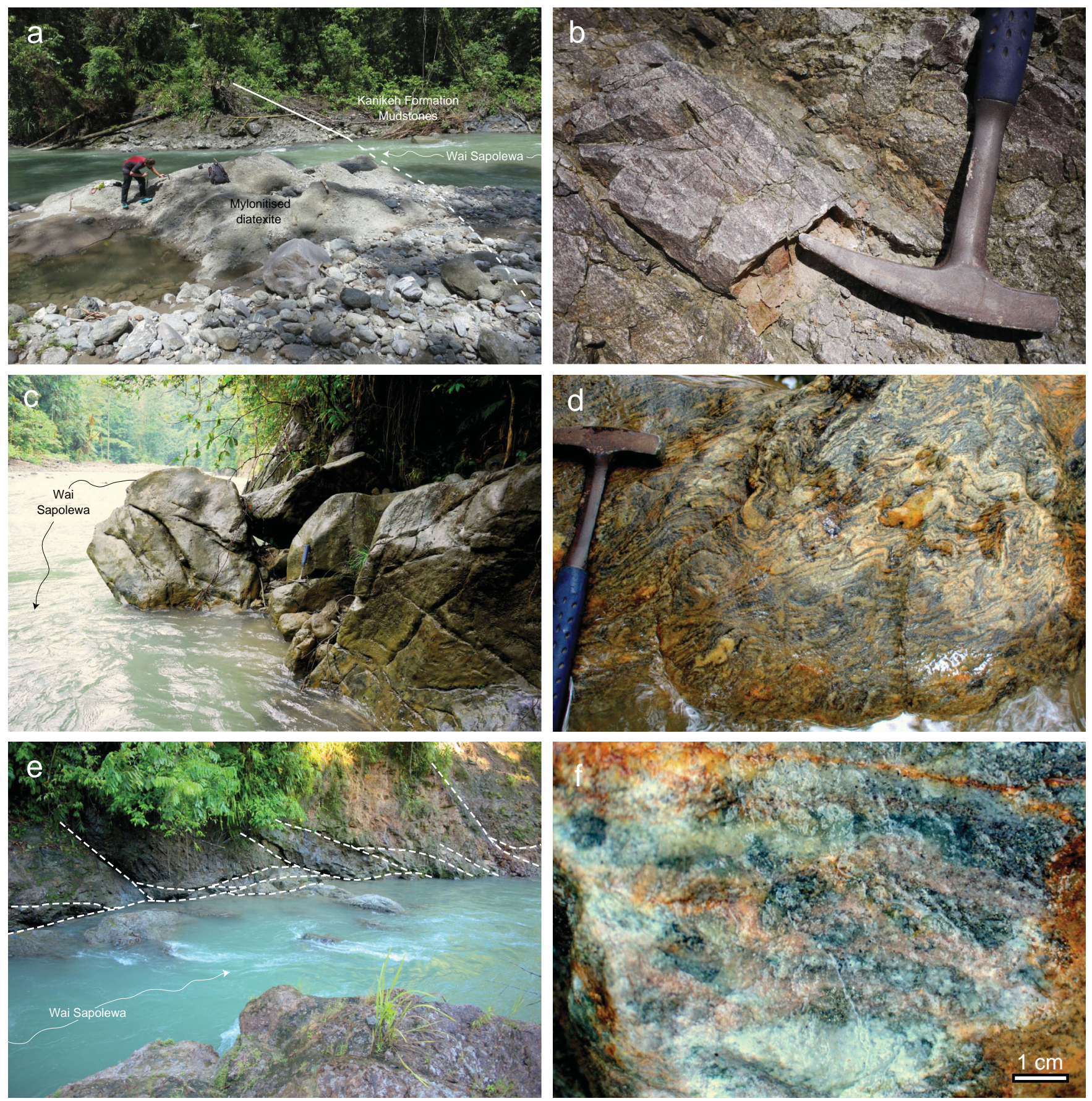

Fig. 16. The Wai Sapolewa, Kobipoto Mountains. (a) Mylonitised diatexite faulted beneath siltstones near the juncture of the Wai Wa $\left(129.4530^{\circ} \mathrm{E}, 3.0201^{\circ} \mathrm{S}\right)$; (b) Close-up of the granulites shown in photo (a) displaying compositional banding between garnet + cordieriterich and quartzofeldspathic domains; (c) In situ lherzolites exposed in the Wai Sapolewa near the junction with the Wai Sahoku (129.4456 ${ }^{\circ}$, $\left.3.0285^{\circ} \mathrm{S}\right)$. See Fig. $18 \mathrm{f}$ for thin section; (d) Deformed stromatic metatexite boulder from the Wai Sahoku $\left(129.4422^{\circ} \mathrm{E}, 3.0282^{\circ} \mathrm{S}\right)$; (e) Lowangle faults within a large exposure of high-temperature granulite facies gneisses by the Wai Sapolewa $\left(129.4454^{\circ} \mathrm{E}, 3.0303^{\circ} \mathrm{S}\right)$ adjacent to the lherzolites shown in photo (c); (f) Garnet-rich granulite from the outcrop shown in photo (e).

chrome spinel, are exposed at the junction of the small Wai Sahoku and share a faulted contact with granulites to their south. The close association of high-temperature granulites with mantle peridotites is surely not coincidental. High- temperature $\left(>800^{\circ} \mathrm{C}\right)$ metamorphism and anatexis was almost certainly driven by heat supplied by the adjacent ultramafic rocks. 
Travelling further upstream from the lherzolites, a sequence of deformed stromatic metatexites (Fig. 16d) and a large outcrop of diatexites with pink garnet-rich and greygreen pinitised cordierite-rich banding are present (Fig. 16f). Both the peridotites and granulites are cut by numerous lowangle listric faults that flatten into subhorizontal detachments (Fig. 16e).

Our traverse ended at another exposure of peridotites that are faulted to the south of the aforementioned banded diatexites. We were unable to continue upstream past this point, but our local guides were adamant that black peridotites also form a steep gorge at the point where the Wai Sima enters the Wai Sapolewa. This feature would seem plausible, as the stream junction is located within the same fault-bound slice we have interpreted from the ASTER data, and it would correlate along strike with the serpentinites observed by the 1975 Expedition who crossed the Wai Sima further upstream (see map, Fig. 14).

Also present in the Wai Sapolewa are pieces of Barroviantype mica schists similar to those present over much of western Seram, and it is very probable that they also belong to the Tehoru or Taunusa Complexes. Further upstream, in situ biotite-sillimanite schist was reported by the 1975 Expedition near the confluence of the Wai Bapa and Wai Seri, and schist was reported by Germeraad (1946) from the Gunung Kalafatu area in the southwestern region of the mountains (see map, Fig. 14).

Many previous authors (Audley-Charles et al., 1979; Tjokrosapoetro and Budhitrisna, 1982; de Smet and Barber, 1992; Kemp and Mogg, 1992; Bachri, 2011) have used the Kobipoto Complex as an umbrella term for all non-sedimentary rocks in the Kobipoto Mountains, thereby grouping these schists with the migmatite complex and the peridotites. We feel that this term is misleading because it does not acknowledge the many similarities between the Kobipoto region and the Kaibobo and Hoamoal peninsulas of western Seram, and also it implies the likely Mio-Pliocene granites are a similar age to the older Tehoru/Taunusa Complex. We propose the migmatite-peridotite complex in the Kobipoto Mountains is equivalent to the cordierite graniteperidotite complex exposed over much of western Seram, and indeed also on Buru (Linthout et al., 1989), Ambon, Seram, Kasiui, Tioor, and the Kai Islands. Therefore, we apply the term "Kobipoto Complex" to all granulites, granulitefacies migmatites, and cordierite granites wherever they occur in the northern Banda Arc, and acknowledge that both the Kobipoto Complex and Tehoru/Taunusa complexes are present in the Kobipoto Mountains.

\subsubsection{Wai Tuh}

The Wai Tuh (spelt "Toehoe" by Germeraad, 1946) has previously been traversed by the 1975 University of London expedition and is mentioned by Audley-Charles et al. (1979). Unlike the Wai Sapolewa, the river unfortunately affords no in situ exposures of the Kobipoto Complex migmatites or peridotites. However, it contains many huge (metre-scale) blocks of each of these lithologies that cannot have moved far from their source (e.g. Fig.17a). Often, these boulders are fresher and have proved more useful from a petrological standpoint than in situ exposures of the Wai Sapolewa.

Huge "cordierite granite" diatexite boulders (Fig. 17b) are peppered with schlieren and schollen of residual granulite to a greater extent than observed in western Seram. The voluminous leucosomes contain fairly abundant garnet porphyroblasts which likely formed as the peritectic products of biotite-consuming, melt-producing reactions. Cordierite is often associated with the residuum and is often partially pinitised. Several smaller boulders of metatexite are present that contain in situ leucosomes and residual garnet + cordierite + sillimanite + spinel + corundum schlieren and have developed complex nebulitic structures recording evidence of extensive high-temperature deformation (Fig. 17c). Huge blocks of peridotite and peridotite breccias are located in the same sections of river as the migmatite boulders (Fig. 17e), again demonstrating their close association.

Breccias of meta- and diatexites that crop out in the walls of the Wai Tuh gorge (Fig. 17a, e) are similar to the partially brecciated mylonitic diatexite encountered at the juncture of the Wai Sapolewa and Wai Wa (Fig. 16a). It would appear that the Wai Tuh diatexites have been subject to more intensive cataclasis, and the resultant breccias represent more-orless in situ bodies as opposed to having been deposited far from their source. The fact that these granulite breccias do not contain clasts of any other rock type supports this interpretation.

Our most important find from the Wai Tuh is a highly residual granulite boulder with a highly aluminous and dry assemblage of garnet + cordierite + sillimanite + spinel + corundum + quartz + ilmenite + plagioclase \pm biotite (Fig. 17d). It can be seen in thin section (Fig. 18a) that abundant large garnets (20-25 vol\%) are surrounded by reaction corona of cordierite + quartz symplectite, sillimanite (likely as pseudomorphs after kyanite), and cordierite + hercynite + corundum symplectite. Coexisting hercynite + quartz are preserved as small inclusions within the garnets and represent the peak metamorphic assemblage - a characteristically high-temperature assemblage that has been reported from several UHT $\left(>900^{\circ} \mathrm{C}\right)$ localities (Lal et al., 1987; Sandiford et al., 1987; Waters, 1991; Dasgupta et al., 1995; Ouzegane and Boumaza, 1996; Morimoto et al., 2004; Tsunogae and Santosh, 2006). Reaction structures within the garnet corona are indicative of near-isothermal decompression, and so record the exhumation history of the Kobipoto Complex in the Kobipoto Mountains. It is anticipated that the thermobarometry of the high-temperature Kobipoto Complex residual granulites will be the subject of future work. 

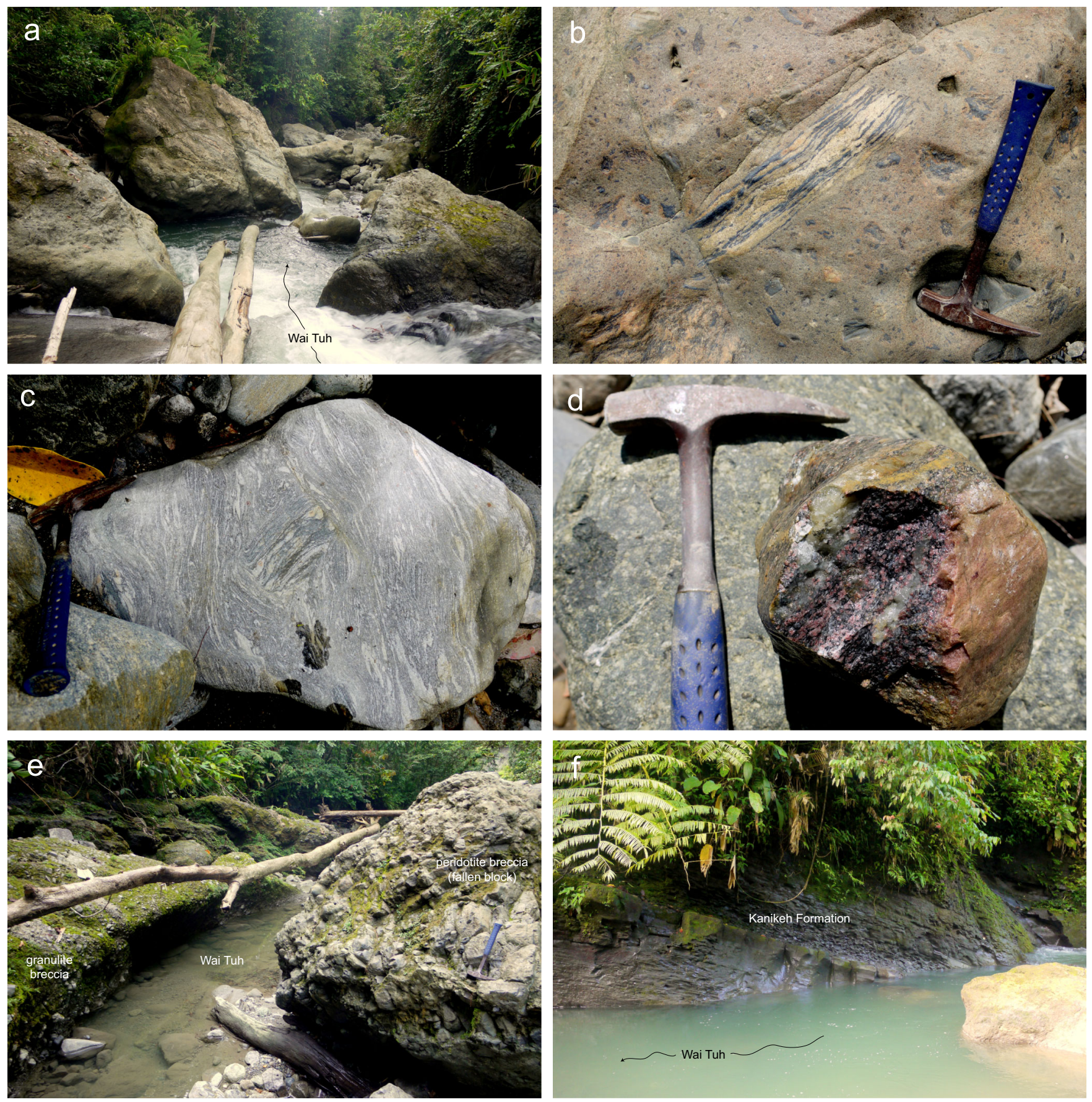

Fig. 17. The Wai Tuh, Kobipoto Mountains. (a) Huge blocks of peridotite breccias collapsed into the Wai Tuh $\left(129.4795^{\circ} \mathrm{E}, 2.9951^{\circ} \mathrm{S}\right)$; (b) Cordierite granite boulder containing large gneissose granulite schollen and sillimanite-spinel schlieren $\left(129.4798^{\circ} \mathrm{E}, 2.9994^{\circ} \mathrm{S}\right)$; $(\mathbf{c})$ Metatexite boulder $\left(129.4786^{\circ}\right.$ E, $\left.3.0018^{\circ} \mathrm{S}\right)$; (d) Highly residual garnet-cordierite-sillimanite-spinel-corundum-quartz granulite boulder collected from the Wai Tuh (see Fig. 18a for thin section photomicrograph; $129.4785^{\circ} \mathrm{E}, 3.0019^{\circ} \mathrm{S}$ ); (e) In situ breccias of diatexite granulites (left) and block of peridotite breccia (right) $\left(129.4802^{\circ} \mathrm{E}, 3.0000^{\circ} \mathrm{S}\right)$; (f) Undeformed, gently dipping beds of Kanikeh Formation mudstones of the upstream section of the Wai Tuh, which alternates with granulite breccias as shown in photo (e) $\left(129.4759^{\circ} \mathrm{E}, 3.0216^{\circ} \mathrm{S}\right)$.

We emphasise that the cordierite granites, granulitefacies metatexites, and garnet-rich residual granulites almost certainly represent different components of the same migmatite complex, generated by partial melting of a dominantly (meta-)pelitic protolith. The coexistence of highly residual granulites and voluminous granitic diatexites (the "cordierite granites") shows the Kobipoto Complex migmatites to be highly segregated. A plethora of 
migmatite boulders (e.g. Fig. 17c) record varying degrees of partial melting across the metatexite-diatexite transition, with garnet + cordierite + sillimanite + spinel + corundum residuum and cordierite + garnet + biotite + plagioclase $+\mathrm{K}$ feldspar + quartz leucosome present in differing proportions. The entire migmatite spectrum is therefore represented: residual granulites from which melt has been extracted (Fig. 18a); metatexites containing in situ granitic leucosomes and granulite facies residuum (Fig. 18b); "cordierite granites", better described as granitic diatexites, which dominantly comprise granitic leucosomes formed from segregated melt but which also have incorporated abundant small schlieren of residuum (Fig. 18c); and lastly cordierite + garnet dacites, or "ambonites" (see Sect. 3.6.3; Fig. 18e), which were sourced from melts extracted from the migmatite complex and have erupted residual granulite xenoliths (Fig. 18e). Each of these rock types has undergone slight metasomatism, with cordierite having frequently been partially or fully pinitised, and in some places the granulites have been cut by pyrite-bearing quartz veins.

Considering the recent extreme metamorphism and melting of the Kobipoto Complex, it is puzzling why the sedimentary rocks in the interspersed fault blocks are completely unaffected. Three possible suggestions have been given for this: Germeraad (1946) considered the migmatite complex to represent a series of exhumed tectonic slices which have punctured overlying sedimentary units; Audley-Charles et al. (1979) later suggested the so-called "Wai Tuh Beds" are a young unconformable deposit on top of their theorised "Kaibobo Complex" allochthon; and de Smet and Barber (1992) instead proposed that the sedimentary rocks are exposures of the Mesozoic Kanikeh Formation which lie underneath their hypothesised thrust contact. Based on our mapping and the arguments against a thrust-related origin for the peridotites and Kobipoto Complex rocks as discussed for western Seram (Sect. 3.1), the suggestions by AudleyCharles et al. (1979) and de Smet and Barber (1992) do not seem plausible. We instead interpret the fault-bounded mudstones and siltstones to be Kanikeh Complex rocks that have dropped between vertically exhumed slices of Kobipoto and Taunusa Complex rocks within a large left-lateral strike-slip positive flower pop-up structure (Fig. 15). This proposal is largely based on the interpretation of prominent topographic lineations present in the ASTER data across the Kobipoto Mountains, as outlined later in Sect. 4.

\subsection{Ambon}

Ambon comprises two separate islands, Latimor and Hitu, which are connected by a short isthmus NE of Ambon City. Latimor contains cordierite granites seated within serpentinised peridotites, which are partially overlain by dacites. The dacites contain abundant cordierite and garnet phenocrysts and were considered sufficiently unusual to have been named "ambonites" after the island (Verbeek, 1905). At
Tanjung Nusanive on the southwesternmost point of Latimor, spectacular pillow basalts are present. Hitu is dominated by two inactive volcanoes formed primarily of ambonites and associated tuffs. Uplifted Quaternary coral reefs flank the islands.

\subsubsection{Peridotite-granite contact relations}

Central Latimor is host to a large $(10 \times 8 \mathrm{~km})$ cordierite granite body we refer to as the Latimor Granite. This is by far the largest granitoid body observed on Seram or Ambon, and so it is strange that it was omitted from the latest GRDC map (Tjokrosapoetro et al., 1993a) and was not acknowledged by some subsequent studies that used this map (e.g. Monnier et al., 2003). The granite is almost identical to that previously described from Seram, and is also characterised by abundant schlieren of granulite residuum.

The Latimor Granite was also found to be exclusively in contact with serpentinised peridotites, which together belong to our reclassified Kobipoto Complex. Notably, large bodies of granophyric leucogranites, in addition to the dykes, are present at the very margin of the Latimor Granite, as previously described for the Kaibobo Peninsula; it would therefore seem extremely probable that the leucogranites have been generated along the granite-peridotite interface before being injected both outward into the enveloping peridotites (Fig. 19a) and inward into the cordierite granites (Fig. 19e). Granite boulders are also present on Hitu by the coast near to the island's southernmost point. As expected, they are bordered to the east and west by serpentinised peridotites.

Granite-peridotite relations are in general better exposed on Ambon than on Seram. In presenting their argument that the ultramafic complex represents an allochthonous thrust sheet, Audley-Charles et al. (1979) made reference to Tanjung Seri $\left(128.1696^{\circ} \mathrm{E}, 3.7507^{\circ} \mathrm{S}\right)$, mentioned briefly by Hutchison (1976), where mantle peridotites are reportedly obducted over and intruded by the Latimor Granite. Our visit to this locality (Fig. 19b) confirms that a sizeable $(5 \times 20 \mathrm{~m})$ fragment of serpentinised peridotite has indeed been thrust over leucogranites. Also at this locality, the leucogranites must have intruded the peridotites as evidenced by the inclusion of large ultramafic xenoliths (Fig. 19c). However, we conclude that these field relations do not support the Seram Ophiolite hypothesis for the following reasons. Firstly, there are no shear fabrics present in the granitoids beneath the peridotite fragment, indicating the thrust must have operated in the brittle regime and so cannot belong to a hightemperature shear zone beneath a hot ophiolite. Secondly, the thrust does not appear to be laterally extensive and so we conclude it has little regional significance. Thirdly, just $20 \mathrm{~m}$ to the east, a subvertical intrusive contact between peridotite and granitic rocks is exposed along which the aforementioned peridotite xenoliths are located (Fig. 19c), which appears the most typical contact relationship. And fourthly, it was the leucogranite, not the cordierite granite, that intruded 

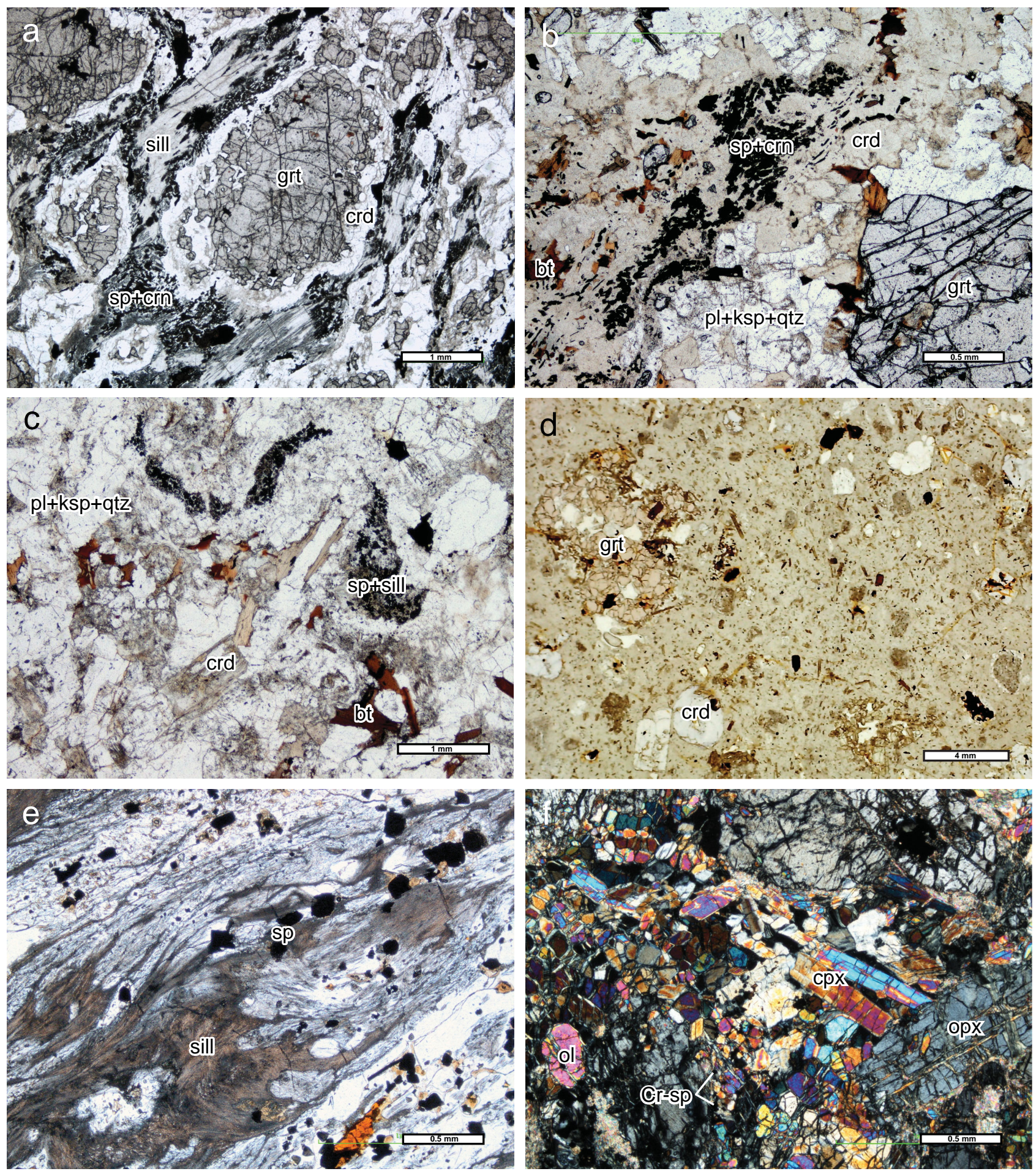

Fig. 18. (a-e) The migmatite-ambonite series of Seram and Ambon. Each rock in the sequence is "fingerprinted" by spinel + sillimanite assemblages and the presence of garnet and cordierite. (a) Highly residual (?U)HT garnet + cordierite + sillimanite + spinel + corundum + quartz granulite. (b) Metatexites containing some quartzofeldspathic domains but retaining the residual high-temperature assemblage present in (a). Cordierite is almost completely pinitised. (c) "Cordierite granite" diatexite containing biotite and small schlieren of spinel + sillimanite. (d) Ambonite containing garnet and cordierite phenocrysts and granulite-derived xenoliths (e) containing mats of fibrolitic sillimanite with spinel which is associated with cordierite. These rocks (a-e) are representative of Kobipoto Complex rocks present throughout Seram and Ambon over a distance of a few hundreds of $\mathrm{km}-$ (a) and (b) are from the Kobipoto Mountains, (c) is from the Kaibobo Peninsula, and (d,e) is from northern Hitu. The heat source for the widespread high-temperature metamorphism and melting is exhumed lherzolite (f) shown in this example from the Wai Sapolewa, Kobipoto Mountains (outcrop shown in Fig.16c) to contain chrome spinel. 

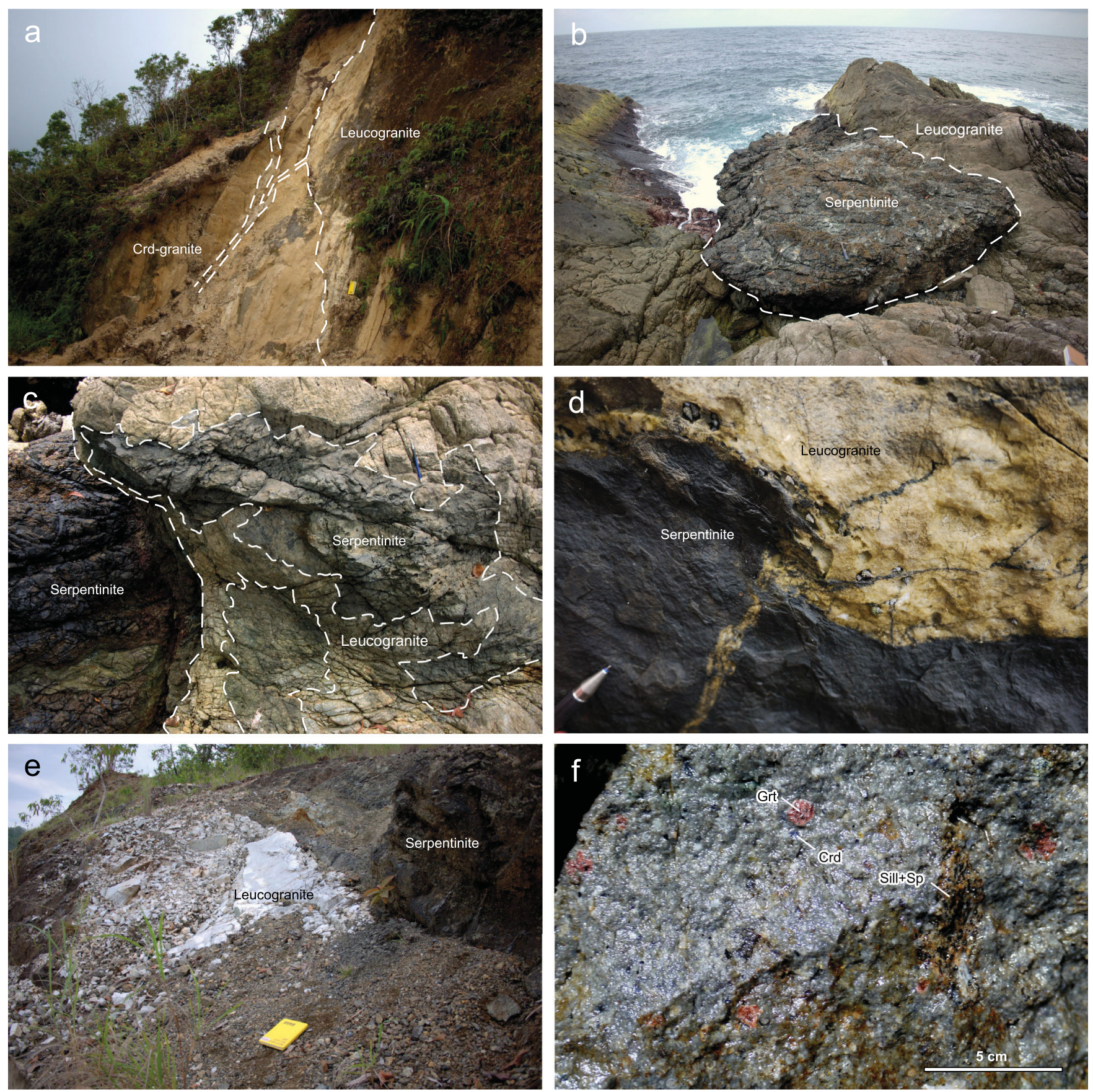

Fig. 19. Field relations on Ambon. (a) Leucogranite intruding cordierite granites, central Latimor (128.2174 $\left.{ }^{\circ} \mathrm{E}, 3.7171^{\circ} \mathrm{S}\right)$; (b) Fragment of serpentinite breccia thrust over chloritised leucogranites on Tanjung Seri, southern Latimor $\left(128.1865^{\circ} \mathrm{E}, 3.7479^{\circ} \mathrm{S}\right)$; (c) $\mathrm{Contact}$ between serpentinite and leucogranite just east of Tanjung Seri along which large xenoliths of serpentinite are included in the leucogranite $\left(128.1866^{\circ} \mathrm{E}, 3.7479^{\circ} \mathrm{S}\right)$; (d) Serpentinite back-veined into leucogranite masking the original intrusion of leucogranite into peridotite, east of Tandjung Seri $\left(128.1866^{\circ} \mathrm{E}, 3.7479^{\circ} \mathrm{S}\right)$; (e) Wide leucogranite dyke intruded through serpentinised peridotites, south Latimor $\left(128.2600^{\circ} \mathrm{E}, 3.7295^{\circ} \mathrm{S}\right)$; (f) Ambonite containing large cordierite and garnet xenocrysts and spinel + sillimanite xenoliths, from northern Hitu $\left(128.0640^{\circ} \mathrm{E}, 3.5930^{\circ} \mathrm{S}\right)$.

the adjacent peridotites. However, we emphasise that it was the hot peridotite, not the leucogranite, which drove this intrusive episode; the peridotites were hotter than the country rocks at the time of juxtaposition, but due to their relative melting points, the leucogranites were the intrusive melts. 
The emplacement of leucogranite into the peridotites was therefore a form of back-intrusion.

There was a later episode of low-temperature serpentinite injection. It is likely that the serpentinisation was associated with hydrothermal alteration of the Kobipoto Complex during exhumation. At Tanjung Seri, the original hightemperature contact features have been obscured (Fig. 19d). Other effects of serpentinisation along the contact can be found further east, inland from the southern Latimor coast (at $128.244^{\circ} \mathrm{E}, 3.736^{\circ} \mathrm{S}$ ) where the undulating contact between peridotites and leucogranites at the margin of the Latimor Granite is exposed in a handful of small outcrops. The leucogranite has been injected by numerous branching veins up to several centimetres wide, seen in thin section to contain serpentine group minerals and chlorite crystallised from fluids that had infiltrated fractures within the leucogranites and caused chloritisation of adjacent feldspars. Large boulders present on the beach downstream from these outcrops clearly display the contact relations. The contact surface between serpentinite and leucogranite is complex and there are numerous serpentinite veins isolating small blocks of leucogranite, demonstrating that injection of serpentinite into the granitoids was a later event than the high temperature intrusion.

\subsubsection{Nature of the Latimor Granite}

We have purposely avoided describing the Latimor Granite and equivalent cordierite granites on Seram as "plutons" to avoid connotations with the conventional model of granites being emplaced into higher structural levels than their place of origin. In other words, we do not not envisage the Latimor or Kaibobo granites being generated at depth before being fed upwards and emplaced into overlying cooled, solid peridotite. On the contrary, we have seen evidence, especially in the Kobipoto Mountains (Sect. 3.5) for cordierite granite formation within a high-temperature migmatite complex as a consequence of the heat supplied by hot mantle peridotites. Therefore, we propose that the contact features previously described from southern Latimor were formed at a crust-mantle interface perhaps represented by a ductile lithospheric shear zone with late-stage serpentinisation and metasomatism having evidently overprinted the contact.

\subsubsection{Ambonites}

Ambonites (crd + grt dacites) are the products of Hitu's two volcanoes. They are also found in northern Latimor, and have been reported from the southern tip of the Hoamoal Peninsula (Tjokrosapoetro et al., 1993b), alongside associated tuffs, volcanic breccias, and agglomorates. There is a definite link between the ambonites and cordierite granites - both rocks contain identical aluminous sillimanite-spinel residua and both feature cordierite and garnet pheno/xenocrysts (Fig. 18d). The ambonites were almost certainly sourced from the Kobipoto Complex. As further evidence, rare cordierite granite fragments are found as xenoliths within the ambonites.

This inference, first made by van Bemmelen (1949), is supported by whole rock $\mathrm{K}-\mathrm{Ar}$ ages for the ambonites of $4.43 \pm 0.10$ to $3.40 \pm 0.15 \mathrm{Ma}$ (Abbott and Chamalaun, 1981) and 4.56 $\pm 0.12 \mathrm{Ma}$ (Honthaas et al., 1999), which are comparable with those $\sim 3.5 \mathrm{Ma} \mathrm{K}-\mathrm{Ar}$ ages reported for the Ambon cordierite granites (Priem et al., 1978).

\section{Interpretation of ASTER DEMs}

Tjokrosapoetro (1976) and Audley-Charles et al. (1979) used satellite imagery and aerial photographs to construct structural maps of Seram. These maps were admirably put together, but can now be improved with the use of highresolution digital elevation models (DEMs) captured by the Shuttle Radar Topography Mission (SRTM) and Advanced Spaceborne Thermal Emission and Reflection Radiometer (ASTER) surveys. The DEM data have revealed the topographic expressions of many faults that have remained inaccessible during our field mapping and have proved invaluable for our tectonic interpretation of the islands (see Fig. 20).

The Kawa strike-slip shear zone (Sect. 3.4), which has the largest topographic expression of all, can accurately be traced along the southern extent of the Manusela Mountains, across the section made accessible by the Trans-Seram highway, and into western-central Seram where it curves westward and splays into multiple strands. The Kawa Fault is offset to the NE by several other prominent steeply dipping (dominantly strike-slip?) faults which share the same $120-300^{\circ}$ strike (Fig. 3b). All these strike-slip faults are connected by Z-shaped sigmoidal restraining bends which jog the trace of the faults to the north when tracked from ESE to WNW. Within each fault-block, smaller antithetic faults, best demonstrated by NW-SE-trending lineations in the Manusela Mountain limestones, appear to have facilitated anticlockwise intra-block rotation and uplift. Thus, a major regional-scale left-lateral strike-slip system is revealed. As previously described (Sect. 3.4), kinematic indicators for the Kawa Fault in the field proved inconsistent, but this fault pattern suggests a left-lateral shear sense for the Kawa Fault is likely the most recent; the Kawa Fault just ESE of the region studied encounters a left-lateral restraining bend where a small pop-up structure has formed.

The Kobipoto Mountains appear to be the largest and most topographically well-defined of all such transpressional popup structures in central Seram. The faults encountered during our river traverses can be traced further east and are interpreted to connect into a sigmoidal array of faults which are located between and link into northern and southern boundary faults (which are parallel to the Kawa Fault) that limit the Kobipoto Mountains against the Central Valley to the south and the flat rainforested plains of northern Seram. The 


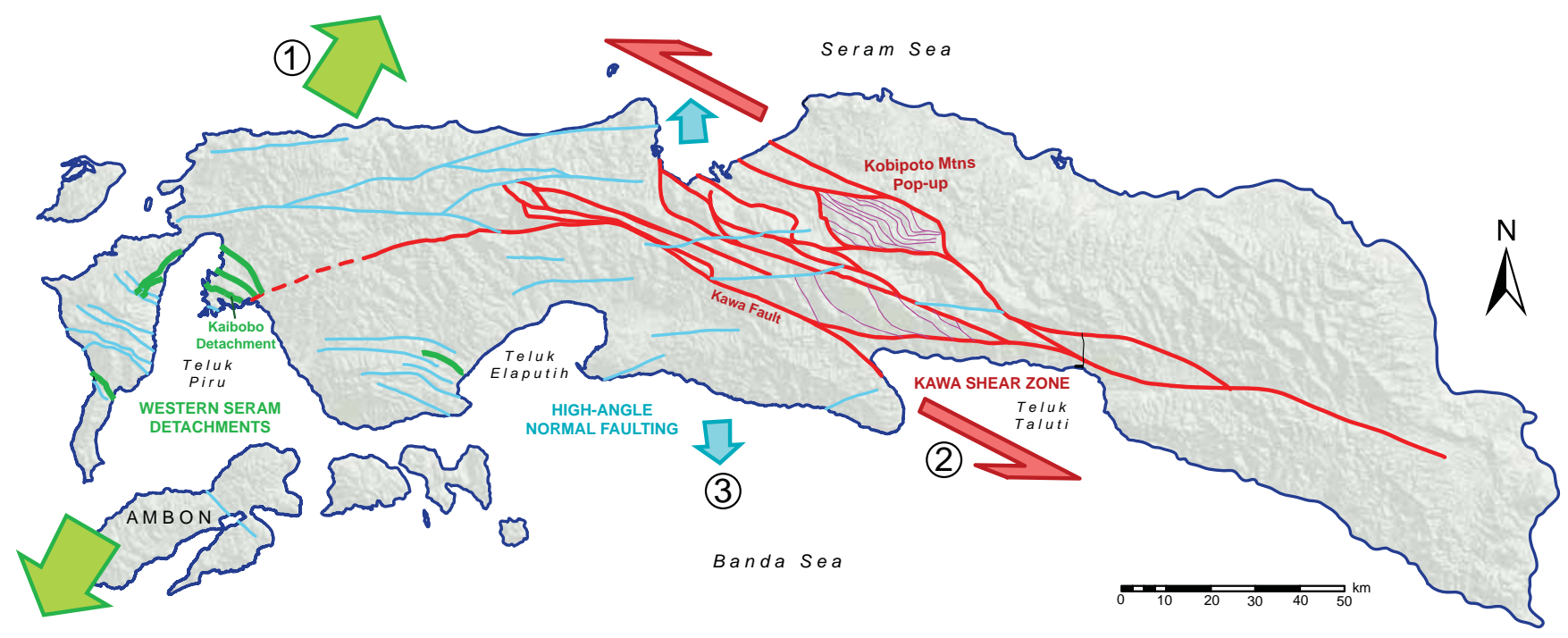

Fig. 20. Structural sketch map of Seram showing detachment faults (green), strike-slip faults (red), high-angle normal faults (blue), and faults within the Kobipoto Mountains strike-slip pop-up structure (magenta) inferred from field observations and DEM interpretation. The relative timings of these three faulting episodes is indicated: Detachment faults strike normal to an inferred NNE-SSW initial extension direction (1); possible subsequent reactivation of detachment faults in central Seram by WNW-ESE left-lateral shear (2) forms the Kawa Shear Zone and Kobipoto Mountains pop-up; late-stage normal faulting in response to slight N-S extension (3) cross-cuts all other structures. The SRTM DEM is used as the base map.

southern Kobipoto boundary fault has a strong topographic expression which was first noticed by Audley-Charles et al. (1979), to the south of which Kanikeh Formation rocks (their "Wakuku Beds") reportedly form a steeply dipping shear zone that locally incorporates lenses of Tehoru/Taunusa Complex schists. As mentioned in Sect. 3.5.3, we interpret the slivers of granulites and granites of the Kobipoto Complex, along with peridotites and Tehoru/Taunusa Complex schists, to have been exhumed by transpression, with blocks of the overlying Kanikeh Formation having dropped down and incorporated into the structure (Fig. 15).

The left-lateral shear may be explained by the combination of two processes: (1) shearing imposed by eastward slab rollback; and/or (2) synthetic Riedel shearing in response to N-S extension. The fault geometries in central Seram are similar to those imaged offshore in the Seram Trough by Teas et al. (2009), who interpreted the Seram Trough fold-and-thrust belt to also have been affected by transpressional left-lateral strike-slip deformation. Therefore, the extent of deformation is shown to extend to the margin of the Bird's Head (Teas et al., 2009).

In western Seram, there are no major strike slip faults apparent in the topography, and this is likely due to the region being dominated by low-angle extensional structures, as mapped out on the Kaibobo Peninsula (Sect. 3.1) and NE Hoamoal peninsula (Sect. 3.2). Whatever the cause for left-lateral shear across central Seram, it has not affected the western region; however as evidenced by the incorporation of exhumed mantle peridotites in both the Kawa Shear Zone and the Kobipoto Mountains, the extreme extension responsible for the structures in western Seram likely did affect the whole island prior to the onset of the strike-slip faulting. Further evidence for this is given by the parallel-alignment between the low-angle Kaibobo Detachment, and the strike-slip faults which dominate central Seram; it would appear likely that the strike-slip faults originated as similar low-angle normal faults which were later reactivated as thrusts with a strong left-lateral shear component.

Post-dating the island's extensive left-lateral shearing, an array of ENE-WSW-trending normal faults have cross-cut the strike-slip structures (Fig. 20). These features, which were also identified by Audley-Charles et al. (1979), seem to relate to a minor NNW-SSE extensional phase. Examples of structures previously described which were likely formed during this more recent episode include the array of normal faults which cross-cut the North Kaibobo Granite and normal faulting within fault gouges of the Kawa Shear Zone.

The timings of these different tectonic episodes have yet to be properly determined. Linthout et al. (1996) reported a 5.65-5.4 Ma age for their supposed ophiolite obduction based on Ar-Ar geochronology of micas formed within Taunusa Complex rocks adjacent to the peridotites on the Kaibobo Peninsula. Although we argue against an ophiolitic origin for the peridotites, their result nevertheless is useful because we instead interpret it to relate to peridotite exhumation by the Kaibobo Detachment. Further microstructurally focussed $\mathrm{Ar}-\mathrm{Ar}$ geochronology of micas formed within different shear zones around Seram would 
allow the tectonic evolution of the island to be better understood.

\section{Discussion and conclusions}

The aim of our field-based reinvestigation into the tectonics of Seram and Ambon was to test the latest hypotheses for Banda Arc evolution that have invoked slab rollback and extension (Hall, 1996, 2002, 2011, 2012; Milsom et al., 2001; Spakman and Hall, 2010) and compare them to previous models that have outlined a thrusting scenario for the islands (Audley-Charles et al., 1979; Linthout et al., 1989, 1991). Central to this problem is deciphering the nature of the widespread peridotites. An ophiolitic origin would support major crustal shortening in order that oceanic lithosphere could have been thrust northwards from the Banda Sea, however there is little evidence to support this hypothesis. The peridotites show no compelling evidence that they belong to an ophiolite - the dominantly fertile lherzolitic compositions and the absence of products from partial melting including basaltic dyke complexes and large-volume gabbros suggest that a subcontinental lithospheric mantle (SCLM) origin is much more likely. Furthermore, there are no other components of an ophiolite present aside from rare gabbro dykes and pillow basalts (restricted to SW Latimor and SE Kelang), and remnants of eroded ophiolite are absent in the sedimentary record. Importantly, no thrust contacts have been observed between the peridotite and the Taunusa metamorphic complex, which has previously been described as its metamorphic sole (Linthout et al., 1989; Linthout and Helmers, 1994). Instead, the peridotites have been observed on the Kaibobo Peninsula (Sect. 3.1) and NW Hoamoal Peninsula (Sect. 3.2) to form the footwall beneath low-angle detachment faults (Fig. 7f). Together, peridotites and cordierite granites comprise a single tectonic unit (both lithologies are cross-cut by the detachment faults) which has been exhumed beneath Tehoru Formation greenschists and amphibolites residing in the hanging wall at $\sim 5.5 \mathrm{Ma}$ in western Seram (ArAr result of Linthout et al., 1996). Evidently, the peridotitecordierite granite complex must have been exhumed before cooling from high temperature to account for the progressive metamorphism and migmatisation of the hanging wall.

It is often not clear from previously published literature (e.g. Tjokrosapoetro et al., 1993a, b) why rocks have been ascribed to the Taunusa Complex as opposed to the Tehoru Formation. We suggest the term "Taunusa Complex" should be applied only to rocks, formerly part of the Tehoru Formation, that have been subsequently overprinted by metamorphism/migmatisation linked to the exhumation of hot peridotite and cordierite granites. This proposal is similar to that of Linthout and Helmers (1994) who suggested the term be restricted to the hypothesised metamorphic sole beneath the supposed Seram Ophiolite.
An exhumed SCLM origin for the peridotites is also supported by geophysical evidence. Milsom (1977) recorded a large +80 mgal Bouguer gravity anomaly over the Kaibobo Peninsula, which is far too great to be accounted for by an ultramafic thrust sheet. Instead, a deep-reaching and highdensity (ultramafic) plug was considered the best solution to the gravity problem. If, as we propose, the Kaibobo Peninsula is a site of mantle exhumation, the subsurface morphology of the peridotite would likely approximate a similar shape.

Previous suggestions that the Pliocene cordierite granites were generated by anatexis within a metamorphic sole seem improbable in light of our new field evidence. There is no inherent link between the basic hornblende diatexites produced from the Taunusa Complex and the pelitic cordierite granites present in the Kobipoto Complex. In any case, the highly localised nature of anatexis observed within the Taunusa Complex would not be sufficient to account for the large volumes of cordierite granites present within the peridotites. Instead, the cordierite granites were evidently generated within the Kobipoto Complex migmatites as indicated by the presence of sillimanite-spinel-corundum granulite residua and cordierite and garnet which likely formed as the peritectic products of melting reactions. However, when considering the protolith for these peraluminous Kobipoto Complex rocks, a (meta-)sedimentary unit such as the Tehoru Formation, which comprises the vast majority of Seram's "basement", is arguably the most likely candidate. So although there is no direct link between the Kobipoto Complex cordierite granites and the Tehoru/Taunusa Complex at the shallow structural levels exposed today in western Seram, the Kobipoto Complex granulites feasibly formed by high-temperature metamorphism and partial melting of Tehoru/Taunusa Complex rocks at depth. Therefore, the Taunusa and Kobipoto complexes are likely just different manifestations of Tehoru Formation metamorphism; the Kobipoto Complex granulite-facies migmatites resulting from a high-temperature metamorphic event driven by hot peridotite juxtaposition, and the Taunusa Complex metamorphic overprint resulting from the high-temperature exhumation of the Kobipoto Complex against further Tehoru Formation rocks located at shallower structural levels (see Figs. 21a and 21b).

This mechanism would explain why not only Kobipoto Complex rocks but Taunusa Complex and Tehoru Formation rocks are incorporated within the Kobipoto Mountains pop-up, and why float samples originating in the inaccessible interior of mid-west Seram display a metamorphic grade mid-way between the Taunusa and Kobipoto complexes. It would also link higher-pressure kyanite-staurolite-garnet schists collected as river float from the Hoamoal Peninsula to the Kobipoto granulites in which kyanite has been mostly pseudomorphed by sillimanite. But most importantly, it demonstrates that the intimate association observed between peridotites, granulite facies migmatites, and cordierite granites in the Kobipoto Mountains extends across the whole 


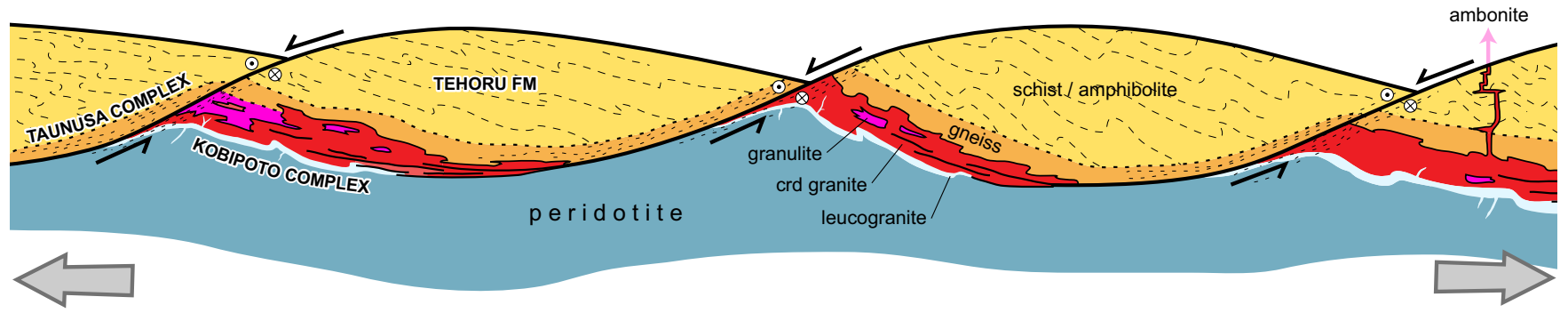

Fig. 21a. Detachment faulting model (schematic) proposed for Seram to explain mantle exhumation by extreme extension driven by Banda Arc slab rollback. The relationship between the Kobipoto Complex (granulites, granites, and associated peridotites), the Taunusa Complex (gneisses and migmatites), and the Tehoru Formation (pre-metamorphosed mica schists and amphibolites) is shown. The detachment faults may have subsequently been reactivated as left-lateral strike-slip faults as observed in the Kawa Fault Zone. See text for discussion.

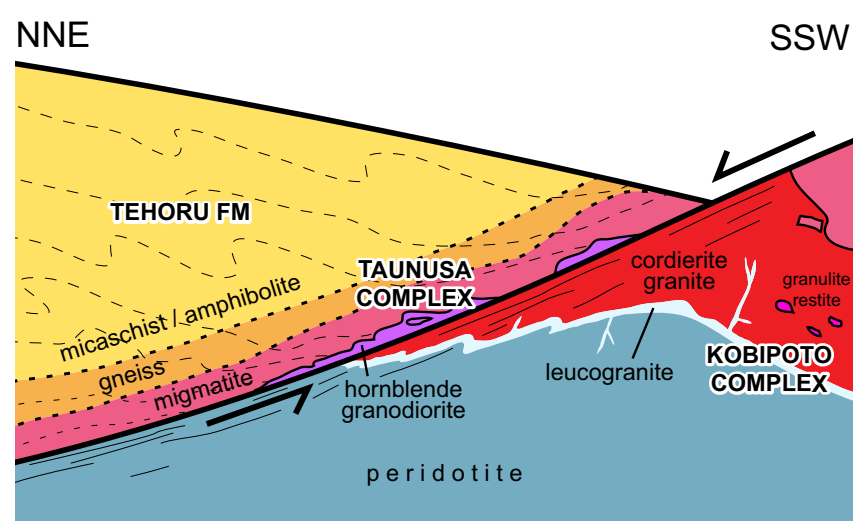

Fig. 21b. Enlargement of part (a) showing more detailed field relations (schematic) in the detachment zone, as observed on the Kaibobo and Hoamoal peninsulas.

of Seram, Ambon, and Buru. Therefore, the cordierite granites of western Seram are shown to be intrinsic members of an extensive granulite-facies migmatite complex that developed under much of the northern Banda Arc islands. As the cordierite granites were produced by in situ partial melting within the Kobipoto Complex migmatites, they should therefore also be considered part of the Kobipoto Complex and not as separate granitoid plutons. Structurally, they are also incorporated into the shear zones associated with the detachment faults. It is likely that the more biotite-rich, schlierenpoor cordierite granites may have experienced some degree of mobilisation, as must the granites and aplites that form feeder dykes to the ambonites, but the vast majority show evidence for being more-or-less in situ bodies.

As previously discussed (Sect. 3.4), the incorporation of sheared lenses of peridotites immediately north of the Kawa Fault hints at the possibility that the shear zone may have originated as a series of detachment faults akin to those preserved in western Seram. It is likely not coincidental that the detachment faults of western Seram and the strike-slip faults of central Seram share the same $120-300^{\circ}$ strike. The Ko- bipoto Mountains left-lateral pop-up structure is related to the Kawa Shear Zone and has evidently facilitated the final stages of Kobipoto Complex exhumation through overlying Kanikeh Formation siltstones as first proposed by Germeraad (1946) based on the observations made by Rutten (1918b) almost a century ago.

The leucogranites, as suggested by Linthout and Helmers (1994), likely represent the final crystallisation product of the cordierite granites which explains why they are concentrated exclusively along the cordierite granite margins. As seen on Latimor (Sect. 3.6.1), the leucogranites intruded the neighbouring peridotites and also injected dykes through the Kobipoto Complex cordierite granites. Peridotite serpentinisation, which must have occurred much later after the whole Kobipoto Complex had cooled, affected the leucogranites more than the cordierite granites owing to their closer proximity, and obliterated the original peridotite-granite contact relations by serpentinite back-veining.

Ambonites are widely regarded as the volcanic equivalent of the cordierite granites owing to the inclusion of cordierite and garnet xenocrysts and granulite-inherited sillimanitespinel xenoliths (Valk, 1945; van Bemmelen, 1949; van Bergen et al., 1989; Linthout and Helmers, 1994; Honthaas et al., 1999). This is supported by geochemical evidence for large-scale crustal assimilation and melt contribution by subducted continental material (e.g. Whitford and Jezek, 1979; Vroon et al., 2001; Nebel et al., 2011). Plio-Pleistocene ages have been reported by Abbott and Chamalaun (1981) and Honthaas et al. (1999) using the K-Ar method, confirming the ambonites are slightly younger than the granites they formed from.

The Kobipoto Complex granulites show evidence for extremely high temperature metamorphism. As previously discussed (Sect. 3.5.3), the coexistence of spinel + quartz and the occurrence of corundum indicate peak metamorphism potentially occurred under UHT $\left(>900^{\circ} \mathrm{C}\right)$ conditions. This may be the most critical line of evidence that conflicts with the Seram Ophiolite hypothesis as in order to have induced 

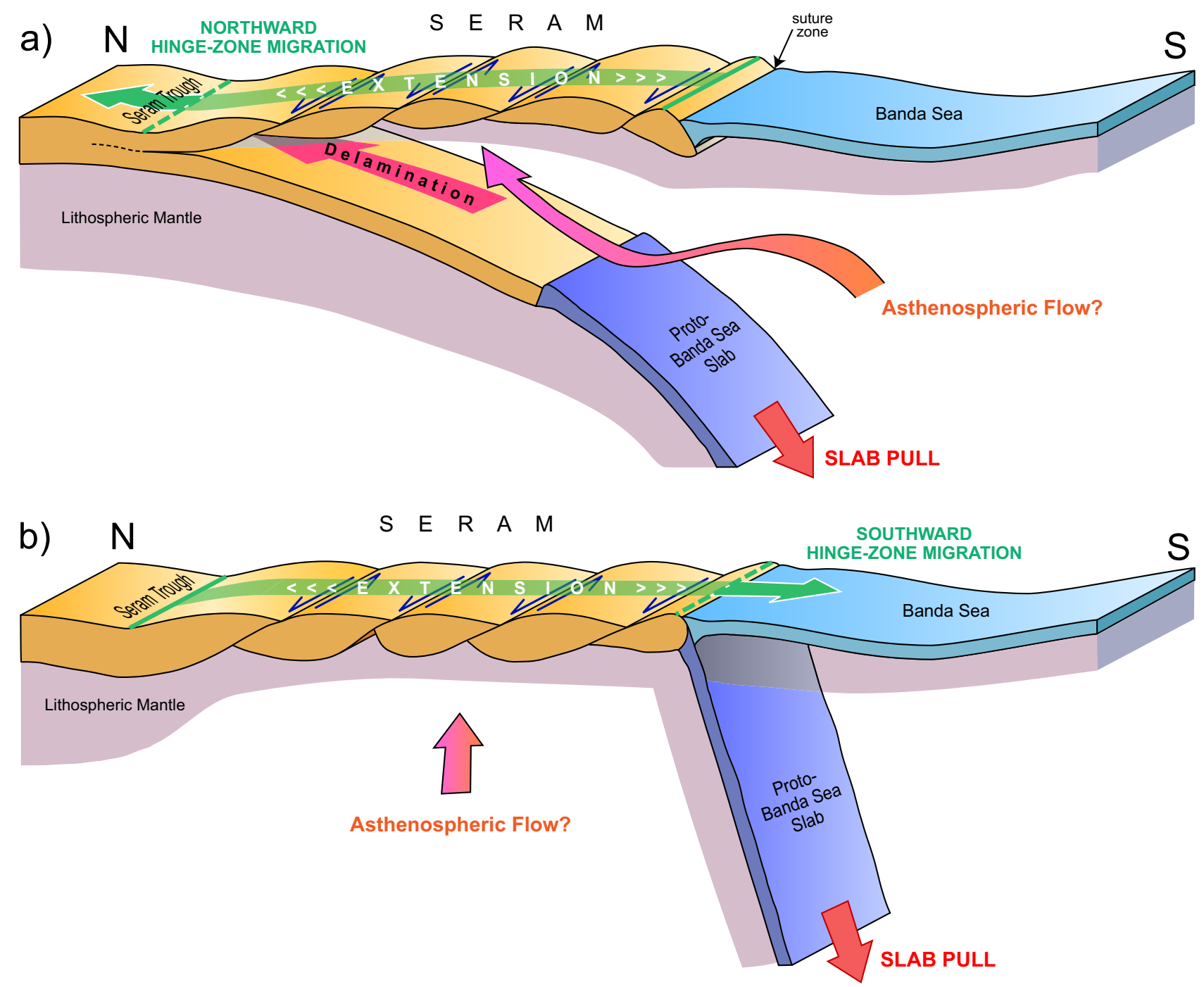

Fig. 22. Two possible tectonic models for extreme extension on Seram: (a) Delamination Model - northward migration of the subduction hinge-zone (green dotted line) has propagated beneath Seram causing lower crustal delamination and mid/upper-crustal extension; (b) Hinge Zone Reversal Model - after complete subduction of the Proto-Banda Sea, continued slab pull has driven a reversal in hinge-zone migration direction due to the resistance of the continental crust to subduction, causing extension within the Australian continental margin to the north. Note that in both scenarios, slab rollback operates to the east (Hall, 2012) and the detachment faults also have left-lateral strike-slip components to their motion. Both cross sections are drawn schematically. See Fig. 21a for details on the boudinaged section of extended crust that is depicted by both models. See text for discussion.

such extreme crustal temperatures, the peridotites themselves cannot have cooled much below typical lithospheric mantle temperatures and so very probably cannot be ophiolitic. The link observed between high-temperature metamorphism and mantle exhumation on Seram is interesting in its own right because the same mechanism may offer a solution to the generation of ancient HT-UHT terranes whose tectonic settings often cannot be directly inferred.

Previously, it has been suggested that mantle injection linked to possible lithospheric delamination could account for crustal melting beneath Seram (Spakman and Hall, 2010).
The delamination hypothesis was originally proposed to partially account for why the surface area of subducted Banda Arc lithosphere is substantially greater than the region enclosed by the Banda Embayment. As revealed by seismic tomography (Widiyantoro and van der Hilst, 1997; Fichtner et al., 2010; Spakman and Hall, 2010) and seismicity patterns (Cardwell and Isacks, 1978; Milsom, 2001; Das, 2004), a tear likely exists in the slab beneath Buru and western Seram (see Fig. 2) which may provide a channel for hot asthenosphere to escape from the beneath the collapsing Proto-Banda Sea. Feasibly, this could have created a thermal 
hot-spot beneath Seram and Ambon which could account for the extremely high geothermal gradient required to attain such high-temperature granulite facies metamorphism.

According to plate reconstructions by Spakman and Hall (2010) and Hall (2012), eastward slab rollback of the ProtoBanda Sea subduction zone likely resulted in highly oblique collision with the Australian continental margin in the vicinity of Seram. In this situation, the continental crust forming Seram and Buru would probably resist being pulled down the subduction zone, but if slab-pull forces were sufficiently high, it is feasible that a subhorizontal tear could have propagated through the deep crust to facilitate continued slab collapse - a scenario that would result in lithospheric delamination. And under such circumstances, asthenospheric mantle would be required to fill the opening void. Supposing that this delamination hypothesis were correct, subduction could have rolled back and propagated "underneath" the whole of Seram, with the Seram Trough likely representing the surface expression of the down-pulling slab. The extensive delamination could have caused the island, now underplated by hot mantle peridotites, to rebound isostatically, extend, and exhume the newly formed Kobipoto Complex (Fig. 22a).

Alternatively, subduction may not have been able to propagate "underneath" Seram due to the inherent resistance of continental crust to being subducted, thereby preventing delamination from having taken place. In this second model, continued slab pull would likely have driven southward migration of the subduction hinge, thereby allowing the slab to straighten and steepen in the mantle. This process would transfer a huge south-directed tug to the continental margin around Seram, drawing out, stretching, and thinning the crust (Fig. 22b). Under such circumstances, it would be plausible that lithospheric detachment faults would propagate in response to the extension, thereby exhuming subcontinental lithospheric mantle in the fashion observed on Seram as implied by the previous model. In this scenario, the apparent area of the embayment would have been decreased due to the contraction around the Australian continental margin. However, this second model cannot as easily explain why the Seram Trough is such a prominent feature.

A quick comparison between these two models (Figs. 22a and 22b) shows obvious and fundamental differences in subduction geometries beneath Seram, but unfortunately it is ambiguous from the tomographic models where the slab is exactly positioned relative to Seram - it could be argued that the data support either model although the implications of both models are identical in that they require an episode of extreme crustal extension that has very likely been driven by slab rollback of the Banda subduction zone. The eastward component of motion may partially account for the leftlateral strike slip Kawa Fault Zone through the centre of the island.

Within the extensional setting of Seram, the Kobipoto Complex could be considered a metamorphic core complex (cf. Whitney et al., 2013). However, the combination of crustal metamorphic rocks and mantle rocks is unusual and conforms to neither continent or oceanic core complex endmember models. Our proposal for core-complex-type peridotite and granulite exhumation on Seram has more similarities with the "mantle core complex" model that has been used to explain the emplacement of the Ronda peridotite in the Betic Cordillera, Spain (Doblas and Oyarzun, 1989). It is unlikely to be a coincidence that the Banda Arc and Betif-Rif Arc of the western Mediterranean (on which the Betic Cordilleras are located) have several similarities (as also noted by Milsom et al., 2001). Both arcs have closeto- $180^{\circ}$ curvatures with similar radii, can be explained in terms of slab rollback, show evidence for continental subduction (Morales et al., 1999), and have peridotites exposed along part of their length. The Beni Bousera peridotite (Rif Mountains, Morocco) is particularly analogous to Seram owing to its association with mylonitised kinzigites (aluminous garnet-sillimanite granulites) which have also been interpreted to form the hanging wall above sheared peridotites exhumed beneath a low-angle detachment (Afiri et al., 2011). Furthermore, the El Hoyazo region of the Betic Cordillera is one of very few other localities aside from Ambon where ambonites have been erupted, which similarly contain xenoliths of their granulitic protolith (Zeck, 1970; Zeck and Williams, 2002; Acosta-Vigil et al., 2010; Álvarez-Valero and Waters, 2010).

Seram has often been portrayed as Timor's mirror image (Audley-Charles et al., 1979), but this new field study has shown Seram to have several features that demonstrate the Banda Arc is far from symmetrical in terms of its tectonic evolution. Whilst Timor may be explained by arc-continent collision (Audley-Charles, 2011), Seram simply cannot be. The island instead provides a rare opportunity to study the interplay of extensional tectonics, mantle exhumation, granulite facies metamorphism, anatexis, and volcanism within a young region of active deformation. We hope this study can provide the foundation for future work in this exciting area of Indonesia.

Acknowledgements. This work certainly would not have been possible without the invaluable field assistance of Yasinto Priastomo and Ramadhan Adhitama (Institut Teknologi Bandung), local guides Pak Jefry, Pak Ende, Pak Yef, Mas Ulis, and Mas Naldo, and our trusty driver Mas Dany. The authors are grateful for the reviews provided by Torgeir Andersen and an anonymous referee, for the comments provided by Martin Norvick, and for editorial assistance by Carmen Gaina. We thank Tony Barber, Gordon Lister, Marnie Forster, Mike Cottam, and Juliane Hennig for useful discussions. Thanks also to Simon Suggate and Benyamin Sapiie for logistical support. This work was undertaken by the SE Asia Research Group at Royal Holloway University of London which has been funded over many years by a consortium of oil companies.

Edited by: C. Gaina 


\section{References}

Abbott, M. J. and Chamalaun, F. H.: Geochronology of some Banda Arc Volcanics, in: The Geology and Tectonics of Eastern Indonesia, edited by: Barber, A. J. and Wiryusujono, S., Geological Research and Development Centre, Special Publication, 2, 253-268, Bandung, 1981.

Acosta-Vigil, A., Buick, I., Hermann, J., Cesare, B., Rubatto, D., London, D., and Morgan, G. B.: Mechanisms of crustal anatexis: a geochemical study of partially melted metapelitic enclaves and host dacite, SE Spain, J. Petrol., 51, 785-821, doi:10.1093/petrology/egp095, 2010.

Afiri, A., Gueydan, F., Pitra, P., Essaifi, A., and Précigout, J.: OligoMiocene exhumation of the Beni-Bousera peridotite through a lithosphere-scale extensional shear zone, Geodin. Acta, 24, 4960, doi:10.3166/ga.24.49-60, 2011.

Álvarez-Valero, A. M. and Waters, D. J.: Partially melted crustal xenoliths as a window into sub-volcanic processes: Evidence from the Neogene Magmatic Province of the Betic Cordillera, SE Spain, J. Petrol., 51, 973-991, doi:10.1093/petrology/egq007, 2010.

Audley-Charles, M. G.: Tectonic post-collision processes in Timor, in: The SE Asian Gateway: History and Tectonics of the Australia-Asia Collision, edited by: Hall, R., Cottam, M. A., and Wilson, M. E. J., Geol. Soc., London, Spec. Pub., 355, 241-266, doi:10.1144/SP355.12, 2011.

Audley-Charles, M. G., Carter, D. J., and Milsom, J. S.: Tectonic development of Eastern Indonesia in relation to Gondwanaland dispersal, Nature, 239, 35-39, doi:10.1038/physci239035a0, 1972.

Audley-Charles, M. G., Carter, D. J., Barber, A. J., Norvick, M. S., and Tjokrosapoetro, S.: Reinterpretation of the geology of Seram: implications for the Banda Arcs and northern Australia, J. Geol. Soc. London, 136, 547-566, doi:10.1144/gsjgs.136.5.0547, 1979.

Bachri, S.: Tectonostratigraphy and structures of eastern Seram, J. Geol. Indonesia, 6, 85-93, 2011.

Barber, A. J., Tjokrosapoetro, S., and Charlton, T. R.: Mud volcanoes, shale diapirs, wrench faults and melanges in accretionary complexes, Eastern Indonesia, AAPG Bull., 70, 17291741, 1986.

Beckinsale, R. and Nakapadungrat, S.: A late Miocene K-Ar age for the lavas of Pulau Kelang, Seram, Indonesia, J. Phys. Earth, 26, 199-201, 1978.

Bock, Y., Prawirodirdjo, L., Genrich J. F., Stevens, C. W., McCaffrey R., Subarya C., Puntodewo S. S. O., and Calais W.: Crustal motion in Indonesia from Global Positioning System measurements, J. Geophys. Res., 108, 2367, doi:10.1029/2001JB000324, 2003.

Boudier, F. and Nicolas, A.: Harzburgite and lherzolite subtypes in ophiolitic and oceanic environments, Earth Planet Sc. Lett., 76, 84-92, 1985.

Bowin, C., Purdy, G. M., Johnston, C., Shor, G., Lawver, L., Hartono, H. M. S., and Jezek, P.: Arc-Continent collision in Banda Sea region, AAPG Bull., 64, 868-915, 1980.

Brouwer, H. A.: Geologische onderzoekingen in Oost-Ceram, Tijd. K. Ned. Aardr. Gen., 36, 715-751, 1919.

Brouwer, H. A.: Over insluitsels en cordierietgehalte van bronzietdacieten van het eiland Ambon, Verhand. Geol. Mijnb. Gen. Nederland. Kol., Geol. Ser. VIII, 73-80, 1925.
Cardwell, R. K. and Isacks, B. L.: Geometry of the subducted lithosphere beneath the Banda Sea in eastern Indonesia from seismicity and fault plane solutions, J. Geophys. Res., 83, 2825-2838, doi:10.1029/JB083iB06p02825, 1978.

Charlton, T. R.: Correlation of the Salawati and Tomori Basins, eastern Indonesia: a constraint on left-lateral displacements of the Sorong fault zone, in: Tectonic Evolution of Southeast Asia, edited by: Hall, R. and Blundell, D., Geol. Soc. London Spec. Pub., 106, 465-481, doi:10.1144/GSL.SP.1996.106.01.29, 1996.

Charlton, T. R.: The petroleum potential of inversion anticlines in the Banda Arc, AAPG Bull., 88, 565-585, doi:10.1306/12290303055, 2004.

Darman, H. and Reemst, P.: Seismic expression of geological features in Seram Sea: Seram Trough, Misool-Onin Ridge and Sedimentary Basin, Berita Sedimentol., 23, 28-34, 2012.

Das, S.: Seismicity gaps and the shape of the seismic zone in the Banda Sea region from relocated hypocenters, J. Geophys. Res., 109, B12303, doi:10.1029/2004JB003192, 2004.

Dasgupta, S., Sengupta, P., Ehl, J., Raith, M., and Bardhan, S.: Reaction textures in a suite of spinel granulites from the Eastern Ghats Belt, India: Evidence for polymetamorphism, a partial petrogenetic Grid in the system KFMASH and the roles of $\mathrm{ZnO}$ and $\mathrm{Fe}_{2} \mathrm{O}_{3}$, J. Petrol., 36, 435-461, 1995.

de Jong, H.: Studien uber Eruptiv- und Mischgesteine des Kaibobogebietes, Geol. Petrogr. and Pal. Results of Explorations in the Isle of Ceram, 1, 1923.

de Smet, M. E. M.: A geometrically consistent plate-tectonic model for eastern Indonesia, Neth. J. Sea Res., 24, 173-183, doi:10.1016/0077-7579(89)90148-8, 1989.

de Smet, M. E. M. and Barber, A. J.: Report on the Geology of Seram (Unpublished Report), Geological Research in Southeast Asia, University of London, UK, 1992.

de Smet, M. E. M., Fortuin, A., Tjokrosapoetro, S., and van Hinte, J.: Late Cenozoic vertical movements of non-volcanic islands in the Banda Arc area, Neth. J. Sea Res., 24, 263-275, doi:10.1016/0077-7579(89)90153-1, 1989a.

de Smet, M. E. M., Sumosusastro, P. A., Siregar, I., Van Marle, L. J., Troelstra, S. R., and Fortuin, A. R.: Late Cenozoic stratigraphy and tectonics of Seram, Indonesia, Geol. Mijnbouw, 68, 221235, $1989 b$.

Deninger, K.: Geographische Ubersicht vom West-Seran, Petermann Geogr. Mitt, 385-388, 1915.

Deninger, K.: Zur Geologie von Mittel-Seran (Ceram), Palaeontographica, Suppl. IV, Beitr. Geologie Niederlandisch-Inden III, 2, 25-58, 1918.

Doblas, M. and Oyarzun, R.: "Mantle core complexes" and Neogene extensional detachment tectonics in the western Betic Cordilleras, Spain: an alternative model for the emplacement of the Ronda peridotite, Earth Planet. Sc. Lett., 93, 76-84, doi:10.1016/0012-821X(89)90185-4, 1989.

Fichtner, A., Kennett, B. L., Igel, H., and Bunge, H.-P.: Full waveform tomography for radially anisotropic structure: New insights into present and past states of the Australasian upper mantle, Earth Planet. Sc. Lett., 290, 270-280, doi:10.1016/j.eps1.2009.12.003, 2010.

Gafoer, S., Suwitodirdjo, K., and Suharsono: Geological map of the Bula and Watubela sheet, Maluku, 1:250000, Geological Research and Development Centre, Bandung, Indonesia, 1993. 
Germeraad, J. H.: Geology of central Seran, in: Geological, petrographical, and palaeontological results of explorations, carried out from September 1917 till June 1919 in the island of Ceram, edited by: Rutten, L. and Hotz, W., 2, 135 pp., De Bussy, Amsterdam, 1946.

Haile, N. S.: Paleomagnetic evidence for the rotation of Seram, Indonesia, J. Phys. Earth, 26, 191-198, 1978.

Hall, R.: Reconstructing Cenozoic SE Asia, in: Tectonic Evolution of Southeast Asia, edited by: Hall, R. and Blundell, D., Geol. Soc. London Spec. Pub., 106, 153-184, doi:10.1144/GSL.SP.1996.106.01.11, 1996.

Hall, R.: Cenozoic geological and plate tectonic evolution of SE Asia and the SW Pacific: computer-based reconstructions, model and animations, J. Asian Earth Sci., 20, 353-431, doi:10.1016/S1367-9120(01)00069-4, 2002.

Hall, R.: Australia-SE Asia collision: plate tectonics and crustal flow, in: The SE Asian Gateway: History and Tectonics of the Australia-Asia Collision, edited by: Hall, R., Cottam, M. A., and Wilson, M. E. J., Geol. Soc. London Spec. Pub., 355, 75-109, doi:10.1144/SP355.5, 2011.

Hall, R.: Late Jurassic-Cenozoic reconstructions of the Indonesian region and the Indian Ocean, Tectonophysics, 570-571, 1-41, doi:10.1016/j.tecto.2012.04.021, 2012.

Hall, R. and Sevastjanova, I.: Australian crust in Indonesia, Aust. J. Earth Sci., 59, 827-844, doi:10.1080/08120099.2012.692335, 2012.

Hall, R. and Wilson, M. E. J.: Neogene sutures in eastern Indonesia, J. Asian Earth Sci., 18, 781-808, 2000.

Hamilton, W.: Tectonics of the Indonesian Region, USGS Professional Paper, 1078, 345, 1979.

Harley, S. L.: Refining the P-T records of UHT crustal metamorphism, J. Metamorph. Geol., 26, 125-154, doi:10.1111/j.15251314.2008.00765.x, 2008.

Harris, R.: Rise and fall of the Eastern Great Indonesian arc recorded by the assembly, dispersion and accretion of the Banda Terrane, Timor, Gondwana Res., 10, 207-231, doi:10.1016/j.gr.2006.05.010, 2006.

Helmers, H., Sopaheluwakan, J., Tjokrosapoetro, S., and Nila, E.: High-grade metamorphism related to peridotite emplacement near Atapupu, Timor with reference to the Kaibobo peridotite on Seram, Indonesia, Neth. J. Sea Res., 24, 357-371, doi:10.1016/0077-7579(89)90161-0, 1989.

Hill, K. C.: Tectonics and regional structure of Seram and the Banda Arc, Proceedings, Indonesian Petroleum Association, 30, 559578,2005

Hinschberger, F., Malod, J., Rehault, J., Villeneuve, M., Royer, J., and Burhanuddin, S.: Late Cenozoic geodynamic evolution of eastern Indonesia, Tectonophysics, 404, 91-118, doi:10.1016/j.tecto.2005.05.005, 2005.

Honthaas, C., Maury, R., Priadi, B., Bellon, H., and Cotten, J.: The Plio-Quaternary Ambon arc, Eastern Indonesia, Tectonophysics, 301, 261-281, doi:10.1016/S0040-1951(98)00227-3, 1999.

Hutchison, C. S.: Discussion of Carter, D. J. et al., 1976, in: Proceedings: Society Meetings September-December 1975, J. Geol. Soc. London, 358-61, 1976.

John, R. and Barber, A. J.: Structure and stratigraphy of the Bula area, Seram. Report of fieldwork programme, OctoberNovember 1989 (Unpublished Report), Geological Research in Southeast Asia, University of London, 1990.
Katili, J. A.: Volcanism and plate tectonics in the Indonesian island arcs, Tectonophysics, 26, 165-188, 1975.

Katili, J. A.: Review of past and present geotectonic concepts of Eastern Indonesia, Neth. J. Sea Res., 24, 103-129, 1989.

Kelsey, D. E.: On ultrahigh-temperature crustal metamorphism, Gondwana Res., 13, 1-29, doi:10.1016/j.gr.2007.06.001, 2008.

Kemp, G. and Mogg, W.: A reappraisal of the geology, tectonics and prospectivity of Seram Island, Eastern Indonesia, Proc. Indonesian Petr. Assoc., 21, 521-552, 1992.

Krumbeck, L.: Geologische Ergebnisse der Reisen K. Deninger's in den Molukken. III. Brachiopoden, Lamellibranchiaten und Gastropoden aus der oberen Trias der Insel Seram (Mittel-Seram), Palaeontographica, Suppl. IV, Beitr. Geologie NiederlandischInden III, 5, 185-246, 1922.

Lal, R. K., Ackermand, D., and Upadhyay, H.: P-T-X relationships deduced from corona textures in sapphirine-spinel-quartz assemblages from Paderu, Southern India, J. Petrol., 28, 1139-1168, 1987.

Linthout, K. and Helmers, H.: Pliocene obducted, rotated and migrated ultramafic rocks and obduction-induced anatectic granite, SW Seram and Ambon, Eastern Indonesia, J. SE Asian Earth Sci., 9, 95-109, doi:10.1016/0743-9547(94)90068-X, 1994.

Linthout, K., Helmers, H., Sopaheluwakan, J., and Nila, E. S.: Metamorphic complexes in Buru and Seram, northern Banda Arc, Neth. J. Sea Res., 24, 345-356, 1989.

Linthout, K., Helmers, H., and Andriessen, P.: Dextral strike-slip in Central Seram and 3-4.5 Ma Rb/Sr ages in pre-Triassic metamorphics related to Early Pliocene counterclockwise rotation of the Buru-Seram microplate (E. Indonesia), J. SE Asian Earth Sci., 6, 335-342, doi:10.1016/0743-9547(91)90079-D, 1991.

Linthout, K., Helmers, H., Wijbrans, J. R., and Van Wees, J. D. A. M.: ${ }^{40} \mathrm{Ar} /{ }^{39} \mathrm{Ar}$ constraints on obduction of the Seram ultramafic complex: consequences for the evolution of the southern Banda Sea, in: Tectonic Evolution of Southeast Asia, edited by: Hall, R. and Blundell, D., Geol. Soc. London Spec. Pub., 106, 455-464, doi:10.1144/GSL.SP.1996.106.01.28, 1996.

Linthout, K., Helmers, H., and Sopaheluwakan, J.: Late Miocene obduction and microplate migration around the southern Banda Sea and the closure of the Indonesian Seaway, Tectonophysics, 281, 17-30, doi:10.1016/S0040-1951(97)00156-X, 1997.

Long, K. L.: Preliminary descriptive deposit model for detachmentfault-related mineralization, US Geol. Surv. Bull., 2004, 52-62, 1992.

Martin, K.: Over de geologie van West-Seran (Ceram), Handeling 8e Nederl. Natuur Geneesk. Congres., Rotterdam, 301-303, 1901.

Martini, R., Zaninetti, L., Lathuillière, B., Cirilli, S., Cornée, J. J., and Villeneuve, M.: Upper Triassic carbonate deposits of Seram (Indonesia): palaeogeographic and geodynamic implications, Palaeogeogr. Palaeocl., 206, 75-102, doi:10.1016/j.palaeo.2003.12.020, 2004.

McCaffrey, R.: Active tectonics of the eastern Sunda and Banda arcs, J. Geophys. Res., 93, 163-182, 1988.

McCaffrey, R.: Seismological contraints and speculations on Banda Arc tectonics, Neth. J. Sea Res., 24, 141-152, 1989.

McCaffrey, R., Silver, E. A., and Rait, R. W.: Crustal structure of the Molucca Sea collision zone, Indonesia, in: The tectonic and geologic evolution of south-east Asian seas and islands, edited 
by: Hayes, D. E., American Geophysical Union, 23, 161-177, 1980.

Milsom, J.: Preliminary gravity map of Seram, eastern Indonesia, Geology, 5, 641-643, 1977.

Milsom, J.: Subduction in eastern Indonesia: how many slabs?, Tectonophysics, 338, 167-178, doi:10.1016/S00401951(01)00137-8, 2001.

Milsom, J., Sardjono, and Susilo, A.: Short-wavelength, highamplitude gravity anomalies around the Banda Sea, and the collapse of the Sulawesi orogen, Tectonophysics, 333, 61-74, doi:10.1016/S0040-1951(00)00267-5, 2001.

Milsom, J. S.: Origin of the Uliasser Islands, eastern Indonesia, J. Geol. Soc. London, 136, 581-582, doi:10.1144/gsjgs.136.5.0581, 1979.

Monnier, C., Girardeau, J., Permana, H., Rehault, J.-P., Bellon, H., and Cotten, J.: Dynamics and age of formation of the SeramAmbon ophiolites (Central Indonesia), B. Soc. Geol. Fr., 174, 529-543, doi:10.2113/174.6.529, 2003.

Morales, J., Serrano, I., Jabaloy, A., Galindo-Zaldívar, J., Zhao, D., Torcal, F., Vidal, F., and González-Lodeiro, F.: Active continental subduction beneath the Betic Cordillera and the Alborán Sea, Geology, 27, 735, doi:10.1130/00917613(1999)027<0735:ACSBTB>2.3.CO;2, 1999.

Morimoto, T., Santosh, M., Tsunogae, T., and Yoshimura, Y.: Spinel + Quartz association from the Kerala khondalites, southern India: evidence for ultrahigh temperature metamorphism, J. Miner. Petrol. Sci., 99, 257-278, 2004.

Nebel, O., Vroon, P., van Westrenen, W., Iizuka, T., and Davies, G.: The effect of sediment recycling in subduction zones on the Hf isotope character of new arc crust, Banda arc, Indonesia, Earth Planet. Sc. Lett., 303, 240-250, doi:10.1016/j.eps1.2010.12.053, 2011.

Nugroho, H., Harris, R., Lestariya, A. W., and Maruf, B.: Plate boundary reorganization in the active Banda Arc-continent collision: Insights from new GPS measurements, Tectonophysics, 479, 52-65, doi:10.1016/j.tecto.2009.01.026, 2009.

O'Sullivan, T., Pegum, D., and Tarigan, J.: Seram oil search, Past discoveries and future oil potential, Proc. Indones. Petrol. Assoc., 14, 3-20, 1985.

Ouzegane, K. and Boumaza, S.: An example of ultrahightemperature metamorphism: orthopyroxene-sillimanite-garnet, sapphirine-quartz and spinel-quartz parageneses in Al-Mg granulites from In Hihaou, In Ouzzal, Hoggar, J. Metamorph. Geol., 14, 693-708, 1996.

Pairault, A. A., Hall, R., and Elders, C. F.: Structural styles and tectonic evolution of the Seram Trough, Indonesia, Mar. Petrol. Geol., 20, 1141-1160, doi:10.1016/j.marpetgeo.2003.10.001, 2003a.

Pairault, A. A., Hall, R., and Elders, C. F.: Tectonic evolution of the Seram Trough, Indonesia, Proc. Indones. Petrol. Assoc., 29, 355-370, 2003b.

Papaioannou, A.: Structure and stratigraphy of central and eastern Seram: Fieldwork Report (Unpublished Report), Geological Research in Southeast Asia, University of London, 1991.

Pieters, P. E., Pigram, C. J., Trail, D. S., Dow, D. B., Ratman, N., Sukamto, R.: The stratigraphy of western Irian Jaya, B. Indones. Geol. Res. Dev. Cent., 8, 14-48, 1983.

Pownall, J. M., Hall, R., and Watkinson, I. M.: Intrusive peridotites and granites exhumed on Seram and Ambon, eastern Indonesia, during Banda Arc subduction rollback, Tectonic Studies Group AGM 2012, Edinburgh, UK, 4-6 January 2012, 2012 a.

Pownall, J. M., Hall, R., and Watkinson, I. M.: Ultra-high temperature metamorphism and anatexis linked to mantle exhumation on Seram, eastern Indonesia, Metamorphic Studies Group Research-in-Progress Meeting 2012, Cambridge, UK, 21 March 2012, 2012b.

Pownall, J. M., Hall, R., Watkinson, I. M., and Forster, M.: Pliocene Mantle Exhumation, granulite facies Metamorphism, and Anatexis driven by Banda Arc Slab Rollback beneath Seram, Eastern Indonesia, 2012 Fall Meeting, AGU, San Francisco, California, USA, 3-7 December 2012, T43E-2712, http://fallmeeting.agu. org/2012/eposters/eposter/t43e-2712/, 2012c.

Pownall, J. M., Hall, R., and Watkinson, I. M.: Granulites from the Kobipoto Mountains of Seram, eastern Indonesia, linked to extensional exhumation of mantle peridotites, Granulites \& Granulites 2013, Hyderabad, India, 16-20 January 2013, 2013 a.

Pownall, J. M., Hall, R., and Watkinson, I. M.: Pliocene extension on Seram and Ambon, eastern Indonesia, linked to mantle exhumation and granulite facies metamorphism, Tectonic Studies Group AGM, Leeds, UK, 3-5 January 2013, 2013 b.

Pownall, J. M., Hall, R., and Watkinson, I. M.: granulite facies metamorphism and melting in the Kobipoto Mountains of Seram, eastern Indonesia, driven by mantle exhumation, Metamorphic Studies Group Research-in-Progress Meeting 2013, Cambridge, UK, 20 March 2013, 2013c.

Price, P. L.: Miospore and phytoplankton assemblages from basement samples, Seram, Indonesia, AAR Ltd., Laboratory Report No. 200/1, 1976.

Price, P. L., O'Sullivan, T., and Alexander, R.: Nature and occurence of oil in Seram, Indonesia, Proc. Indones. Petrol. Assoc., 6, 141$173,1987$.

Priem, H. N. A., Andriessen, P. A. M., Boelrijk, N. A. I. M., Hebeda, E. H., Hutchinson, C. S., Verdurmen, E. A. T., and Versschure, R. H.: Isotopic evidence for a middle to late Pliocene age of the cordierite granite on Ambon, Indonesia, Geol. Mijnbouw, 57, 441-443, 1978.

Rutten, L. M. R.: Uit het eerste verslag over de geologische expeditie naar Ceram, Tijd. K. Ned. Aardr. Gen., 35, 112-121, 1918a.

Rutten, L. M. R.: De geologische expeditie naar Ceram- tweede verslag (13 Aug.- 11 Sept. 1917), Tijd. K. Ned. Aardr. Gen., 35, 228-234, 1918b.

Rutten, L. M. R.: De geologische expeditie naar Ceram- derde verslag (12 Sept.- 11 Nov. 1917), Tijd. K. Ned. Aardr. Gen., 35, 368-378, 1918c.

Rutten, L. M. R.: De geologische expeditie naar Ceram- vierde verslag (12 Nov. 1917-4 Jan. 1918), Tijd. K. Ned. Aardr. Gen., 35, 547-555, 1918d.

Rutten, L. M. R.: De geologische expeditie naar Ceram- vijfde verslag (4 Jan.- einde Maart 1918), Tijd. K. Ned. Aardr. Gen., 36, 36-48, 1919a.

Rutten, L. M. R.: De geologische expeditie naar Ceram- zesde verslag (April - Mei 1918), Tijd. K. Ned. Aardr. Gen., 36, 1919 b.

Rutten, L. M. R.: De geologische expeditie naar Ceram- sevende verslag (Juni-Juli 1918), Tijd. K. Ned. Aardr. Gen., 36, 199-207, 1919c.

Rutten, L. M. R.: De geologische expeditie naar Ceram- achtse verslag., Tijd. K. Ned. Aardr. Gen., 36, 460-466, 1919d. 
Rutten, L. M. R.: Ceram, Ambon, Boeroe en de kleinere eilanden in hunne omgeving, in: Voordrachten over de geologie van Nederlandsch Indie, edited by: Rutten, L. M. R., 716-749, Wolters, Groningen, 1927

Rutten, L. M. R. and Hotz, W.: De geologische expeditie naar Ceram- negende verslag (medio September-medio December 1918), Tijd. K. Ned. Aardr. Gen., 36, 559-579, 1919.

Rutten, L. M. R. and Hotz, W.: De geologische expeditie naar Ceram- tiende verslag (medio September-medio December 1918), Tijd. K. Ned. Aardr. Gen., 37, 17-31, 1920a.

Rutten, L. M. R. and Hotz, W.: De geologische expeditie naar Ceram- elfde (laaste) verslag (13 Aug.-11 Sept. 1917), Tijd. K. Ned. Aardr. Gen., 37, 32-42, 1920b.

Sandiford, M., Neall, F. B., and Powell, R.: Metamorphic evolution of aluminous granulites from Labwor Hills, Uganda, Contrib. Mineral. Petr., 95, 217-225, 1987.

Sawyer, E. W.: Atlas of Migmatites, vol. 9, The Canadian Mineralogist, Special Publication, Ottawa, Canada, 9 Edn., 2008.

Schroeder van der Kolk, J. L. C.: Mikroskopische Studien ueber Gesteine aus den Molukken, pt. 2 - Gesteine von Seran, Geol. Reichs-Museums Leiden, Samml., 6, 1-39, 1902.

Seidel, M., Pack, A., Sharp, Z. D., and Seidel, E.: The Kakopetros and Ravdoucha iron-oxide deposits, western Crete, Greece: fluid transport and mineralization within a detachment zone, Econ. Geol., 100, 165-174, 2005.

Sevastjanova, I., Hall, R., Gunawan, I., Ferdian, F., Decker, J.: Continental crust history in SE Asia: Insights from zircon geochronology, 2012 Fall Meeting, AGU, San Francisco, California, USA, 3-7 December 2012, T11B-2572, http:// fallmeeting.agu.org/2012/eposters/eposter/t11b-2572/, 2012.

Smith, S. A. F., Holdsworth, R. E., and Collettini, C.: Interactions between low-angle normal faults and plutonism in the upper crust: Insights from the Island of Elba, Italy, Geol. Soc. Am. Bull., 123, 329-346, doi:10.1130/B30200.1, 2010.

Spakman, W. and Hall, R.: Surface deformation and slab-mantle interaction during Banda arc subduction rollback, Nat. Geosci., 3, 562-566, doi:10.1038/ngeo917, 2010.

Špičák, A., Matějková, R., and Vaněk, J.: Seismic response to recent tectonic processes in the Banda Arc region, J. Asian Earth Sci., 64, 1-13, doi:10.1016/j.jseaes.2012.11.014, 2013.

Stevens, C. W., McCaffrey, R., Bock, Y., Genrich, J. F., Pubellier, M., and Subarya, C.: Evidence for Block Rotations and Basal Shear in the World's Fastest Slipping Continental Shear Zone in NW New Guinea, in: Plate Boundary Zones, edited by: Stein, S. and Freymueller, J., AGU Geodynam. Ser., 30, 87-99, 2002.

Teas, P. A., Decker, J., Orange, D., and Baillie, P.: New insight into the structure and tectonics of the Seram Trough from SEASTEEP high resolution bathymetry, Proc. Indones. Petrol. Assoc., 33, 2009.

Tjokrosapoetro, S.: The regional structures of Seram Island as interpreted from satellite imagery, Geological Research and Development Centre, Bandung, Indonesia, 1976.

Tjokrosapoetro, S. and Budhitrisna, T.: Geology and tectonics of the northern Banda Arc, B. Indones. Geol. Res. Dev. Cent., 6, 1-17, 1982.

Tjokrosapoetro, S., Rusmana, E., Sukardi, and Achdan, A.: Preliminary geological map of the Ambon Quadrangle, Maluku. Scale 1:250,000, Geological Research and Development Centre, Bandung, Indonesia, 1985.
Tjokrosapoetro, S., Achdan, A., Suwitodirdjo, K., and Abidin: Preliminary geological map of the Masohi Quadrangle, Maluku. Scale 1:250,000, Geological Research and Development Centre, Bandung, Indonesia, 1987.

Tjokrosapoetro, S., Achdan, A., Suwitodirdjo, K., Rusmana, E., and Abidin, H. Z.: Geological map of the Masohi quadrangle, Maluku, 1:250000, Geological Research and Development Centre, Bandung, Indonesia, 1993a.

Tjokrosapoetro, S., Rusmana, E., and Achdan, A.: Geological map of the Ambon sheet, Maluku, 1:250,000, Geological Research and Development Centre, Bandung, Indonesia, 1993b.

Tsunogae, T. and Santosh, M.: Spinel-sapphirine-quartz bearing composite inclusion within garnet from an ultrahigh-temperature pelitic granulite: Implications for metamorphic history and PT path, Lithos, 92, 524-536, doi:10.1016/j.lithos.2006.03.060, 2006.

Valk, W.: Contributions to the geology of West Seran, in: Geological, petrographical, and palaeontological results of explorations, carried out from September 1917 till June 1919 in the island of Ceram, edited by: Rutten, L. and Hotz, W., De Bussy, Amsterdam, 1, 104 pp., 1945.

van Bemmelen, R. W.: The geology of Indonesia, Government Printing Office, Matinus Nijhoff, The Hague, 1949.

van Bergen, M. J., Erfan, R. D., Sriwana, T., Suharyono, K., Poorter, R. P. E., Varekamp, J. C., Vroon, P. Z., and Wirakusumah, A. D.: Spatial geochemical variations of arc volcanism around the Banda Sea, Neth. J. Sea Res., 24, 313-322, 1989.

van der Sluis, J. P.: Geology of East Seran, in: Geological, petrographical, and palaeontological results of explorations, carried out from September 1917 till June 1919 in the island of Ceram, edited by: Rutten, L. and Hotz, W., De Bussy, Amsterdam, 3, 67 pp., 1950.

van Hinte, J. E. and Hartono, H. M. S.: Executive summary of Theme I Snellius-II Expedition "Geology and geophysics of the Banda Arc and adjacent areas”, Neth. J. Sea Res., 24, 95-102, 1989.

Verbeek, R. D. M.: Geologische beschrijving van Ambon, Jaarb. Mijnw. Ned. Oost-Indie, 29, 308, 1905.

Villeneuve, M., Martini, R., Bellon, H., Réhault, J.-P., Cornée, J.J., Bellier, O., Burhannuddin, S., Hinschberger, F., Honthaas, C., and Monnier, C.: Deciphering of six blocks of Gondwanan origin within Eastern Indonesia (South East Asia), Gondwana Res., 18, 420-437, doi:10.1016/j.gr.2009.12.011, 2010.

Visser, W. A. and Hermes, J. J.: Geological results of the exploration for oil in Netherlands New Guinea, Verhandelingen Koninklijk Nederlands Geologisch en Mijnbouwkundig Genootschap, 20, 265, 1962.

Vroon, P., Lowry, D., Van Bergen, M. J., Boyce, A. J., and Mattey, D. P.: Oxygen isotope systematics of the Banda Arc: low $\delta^{18} \mathrm{O}$ despite involvement of subducted continental material in magma genesis, Geochim. Cosmochim. Ac., 65, 589-609, doi:10.1016/S0016-7037(00)00554-8, 2001.

Walker, J. D. and Geissman, J. W.: 2009 Geological Time Scale, Geol. Soc. Am., doi:10.1130/2009.CTS004R2C, 2009.

Wanner, J.: Triaspetrefakten der Molukken und des Timorarchipels, Neues Jahrbuch Min., Geol., Palaont., Beilage Band, 24, 133$160,1907$.

Wanner, J.: Geologische Ergebnisse der Reisen K. Deninger's in den Molukken. I. Beitrage zur Geologie der Insel Buru, Palaeon- 
tographica, Suppl. IV, Beitr. Geologie Niederlandisch-Inden III, 3, 59-112, 1923.

Waters, D. J.: Hercynite-quartz granulites: phase relations and implications for crustal processes, Eur. J. Mineral., 3, 367-386, 1991.

Watkinson, I. M., Hall, R., Cottam, M. A., Sevastjanova, I., Suggate, S., Gunawan, I., Pownall, J. M., Hennig, J., Ferdian, F., Gold, D., Zimmermann, S., Rudyawan, A., and Advocaat, E.: New Insights Into the Geological Evolution of Eastern Indonesia From Recent Research Projects by the SE Asia Research Group, Berita Sedimentol., 23, 21-27, 2012.

Whitford, D. J. and Jezek, P. A.: Origin of late Cenozoic lavas from the Banda Arc, Indonesia: trace elements and $\mathrm{Sr}$ isotope evidence, Contrib. Mineral. Petr., 68, 141-150, 1979.

Whitney, D. L., Teyssier, C., Rey, P., and Buck, W. R.: Continental and oceanic core complexes, Geol. Soc. Am. Bull., 125, 273298, doi:10.1130/B30754.1, 2013.
Widiyantoro, S. and van der Hilst, R.: Mantle structure beneath Indonesia inferred from high-resolution tomographic imaging, Geophys. J. Int., 130, 167-182, 1997.

Widiyantoro, S., Pesicek, J. D., and Thurber, C. H.: Complex structure of the lithospheric slab beneath the Banda arc, eastern Indonesia depicted by a seismic tomographic model, Res. Geophys., 1, 1-6, doi:10.4081/rg.2011.e1, 2011.

Zeck, H. P.: An erupted migmatite from Cerro del Hoyazo, SE Spain, Contrib. Mineral. Petr., 26, 225-246, 1970.

Zeck, H. P. and Williams, I. S.: Inherited and magmatic zircon from neogene Hoyazo cordierite dacite, SE Spain - Anatectic source rock provenance and magmatic evolution, J. Petrol., 43, 10891104, 2002.

Zillman, N. J. and Paten, R. J.: Exploration and petroleum prospects, Bula Basin, Seram, Indonesia, Proc. Indones. Petrol. Assoc., 4, 129-148, 1975. 